\title{
Modulation of fetal hemoglobin in sickle cell anemia
}

Citation for published version (APA):

Saleh, A. W. (1998). Modulation of fetal hemoglobin in sickle cell anemia. [Doctoral Thesis, Maastricht University]. Universiteit Maastricht. https://doi.org/10.26481/dis.19981030as

Document status and date:

Published: 01/01/1998

DOI:

10.26481/dis.19981030as

Document Version:

Publisher's PDF, also known as Version of record

\section{Please check the document version of this publication:}

- A submitted manuscript is the version of the article upon submission and before peer-review. There can be important differences between the submitted version and the official published version of record.

People interested in the research are advised to contact the author for the final version of the publication, or visit the DOI to the publisher's website.

- The final author version and the galley proof are versions of the publication after peer review.

- The final published version features the final layout of the paper including the volume, issue and page numbers.

Link to publication

\footnotetext{
General rights rights.

- You may freely distribute the URL identifying the publication in the public portal. please follow below link for the End User Agreement:

www.umlib.nl/taverne-license

Take down policy

If you believe that this document breaches copyright please contact us at:

repository@maastrichtuniversity.nl

providing details and we will investigate your claim.
}

Copyright and moral rights for the publications made accessible in the public portal are retained by the authors and/or other copyright owners and it is a condition of accessing publications that users recognise and abide by the legal requirements associated with these

- Users may download and print one copy of any publication from the public portal for the purpose of private study or research.

- You may not further distribute the material or use it for any profit-making activity or commercial gain

If the publication is distributed under the terms of Article $25 \mathrm{fa}$ of the Dutch Copyright Act, indicated by the "Taverne" license above, 


\section{Modulation of Fetal Hemoglobin in Sickle Cell Anemia}


- A Saleh, Curaçao 1998.

Layout: Alexander Saleh

Cover illustration by Clemens Evertsen (Interphoto)

The studies in this thesis were raade possible by financial support of the NetherlandsAntillean Foundation for Clinical Education (NASKHO) and the company Bristol-Myers Squibb. The printing of this thesis was financially supported by Bristol-Meyers Squibb. 


\title{
Modulation of Fetal Hemoglobin in Sickle Cell Anemia
}

\author{
PROEFSCHRIFT
}

ter verkrijging wan de graad van doctor alan de Universiteit Maastricht, op gezag van de Rector Magnificus,

Prof. Dr. A.C. Nieuwentuijzen Kruseman, volgens het besluit van het College van Decanen, in het openbaar te verdedigen

op vrijdag 30 oktober 1998 om 14.00 uur

door

\section{A W Saleh}

geboren op 30 nowember 1959 te Curaçao 


\section{Promotor}

Prof dr HFP Hillen

Prof dr THJ Huisman (University of Georgia, USA)

\section{Beoordelingscommissie}

Prof dr JPM Geraedts (voorzitter)

Prof dr LF Bernini (Rijksuniversiteit Leiden)

Dr K Hamulyàk

Prof dr HC Hemker

Dr FAJ Muskiet (Rijksuniversiteit Groningen) 
Aan mijn ouders

Voor Ann Marie, Caroline en Alexandre 



\section{Contents}

Chapter I: $\quad$ Sickle cell (SS) disease: a review 9

Chapter II: Sickle cell disease in Curaçao

Chapter III: Pharmacological induction of fetal hemoglobin synthesis in sickle cell disease

Chapter IV: Aims of the study and thesis outline

Chapter V: Materials and methods

Chapter VI: Isobutyramide therapy in patients with sickle cell anemia

Chapter VII: Hydroxyurea therapy in sickle cell anemia patients in Curaçao, The Netherlands Antilles

Chapter VIII: Cytokines and soluble adhesion molecules in sickle cell anemia patients during hydroxyurea therapy

Chapter IX: Levels of endothelial, neutrophil and platelet specific factors in sickle cell anemia patients during hydroxyurea therapie

Chapter X: Summary and conclusive remarks

Chapter XI: Samenvatting

Dankwoord

Curriculum vitae 



\section{Chapter I}

\section{Sickle cell (SS) disease: a review}

AW Saleh 


\section{Introduction}

Sickle cell anemia is characterised by the presence of sickled red cells, first described by Herrick in 1910 as peculiar elongated and sickle - shaped red blood corpuscles $^{1}$. The main features of this inherited disease are chronic hemolytic anemia and recurrent pain episodes which are related to the presence of mutant. hemoglobin $S$ within the red blood cells.

Hemoglobins $(\mathrm{Hb}) \mathrm{F}, \mathrm{Hb} \mathrm{A}$ and $\mathrm{Hb} \mathrm{A}_{2}$ represent the normal hemoglobins in postembryonal life. The hemoglobin molecule is constructed as a tetramer which consists of one pair of alpha chains and one pair of non alpha chains ( $\beta$ chain in $\mathrm{HbA}, \gamma$ chain in $\mathrm{HbF}$ and $\delta$ chain in $\mathrm{HbA}_{2}$ ).

Hemoglobin $S$ was discovered by Pauling and collegues in 1949 who reported the different electrophoretic mobilities of $\mathrm{HbS}$ and normal adult hemoglobin $\mathrm{HbA}^{2}$. The work of Ingram ${ }^{3-5}$ has shown that $\mathrm{HbS}$ is the result of replacement of glutamic acid by valine at position 6 in the $\beta$-globin chain.

$\mathrm{HbS}$ is inherited in a familial autosomal co-dominant manner which may result in homozygous SS disease, characterized by the presence of two $\beta^{s}$ genes, and the asymptomatic heterozygous form (HbAS) which carries one normal $\beta^{\wedge}$ and one mutated $\beta^{S}$ gene, known as 'sickle cell trait".

Numerous other abnormal hemoglobins have been identified. Among these, HbC and $\mathrm{E}$ are found in high frequencies. The $\mathrm{HbSC}$ compound heterozygote may result in significant clinical disease resembling that of SS disease.

The other group of hemoglobin disorders are the thalassemias. These disorders may co-exist with HbS. Thalassemias are characterized by an inadequate rate of qualitatively normal $\alpha$ or $\beta$ chain synthesis caused by an alteration in the genes encoding for these chains. The clinical severity is proportional to the degree of imbalance in $\beta$-globin ( $\beta$-thal) or $\alpha$-globin ( $\alpha$-thal) chain production.

The $\beta$-thalassemia genes are categorised into two groups namely those expressing no $\mathrm{HbA}$ at all ( $\beta^{\circ}$ thalassemia) and those expressing reduced amounts of $\mathrm{HbA}\left(\beta^{+}\right.$ thalassemia). $\alpha$-Globin genes normally occupy a double locus. In $\alpha$-thalassemia different levels of disease severity result from deletions in one ( $\alpha$-thal-2) or both of the $\alpha$ gene loci ( $\alpha$ thal-1).

The inherited hemoglobin disorders are among the most common single gene disorders in the world. They already place a significant burden on health services. Therefore, it is of importance that management of these diseases focuses on prevention of severe forms (genetic counseling and prenatal diagnosis) and on research of the pathophysiological and molecular mechanisms, thereby creating new treatment strategies. 


\section{Molecular basis of the $\alpha$ - and $\beta$-globin genes}

Genes that determine the synthesis of globin chains are organized in two clusters on different chromosomes. In each cluster the genes are organized $5^{\prime} \rightarrow 3^{\prime}$ in the same order that they are switched on during development. As the major site of erythropoiesis shifts from the yolk sac to the liver and than to the bone marrow, the globin synthesis switches from $\zeta$ and $\epsilon$-globin to $\alpha$ and $\gamma$-globin, and at birth to $\alpha, \beta$ and $\delta$-globin, respectively ${ }^{6,7}$.

The $\beta$-like globin gene cluster covers a region of approximately $60 \mathrm{~kb}$ on the short arm of chromosome $\# 11$ (Figure 1.1). It contains 5 functional genes (the $\epsilon,{ }^{0} \gamma,{ }^{A} \gamma, \delta$ and $\beta$-genes) and one pseudo-gene $\psi \beta$ (pseudo-genes resemble functional genes but lack a critical component of the gene structure necessary for expression). The polypeptide chains produced by both $\gamma$ genes differ in only one amino acid at position 136. The ${ }^{\mathrm{a}} \gamma$ chain has glycine, whereas the ${ }^{\mathrm{A}_{\gamma}}$ chain has alanine. Sometimes a variant ${ }^{A} \gamma$ chain is detected which is characterized by an isoleucine $\rightarrow$ threonine replacement at position 75 . Transcription of the $\beta$-like globin genes is regulated by distant sequences (so-called hypersensitive sites) on the same chromosome, known as the Locus Control Region (LCR), located 6 to $20 \mathrm{~kb} 5^{\prime}$ to the $\epsilon$-globin'. By interacting with proteins in it's environment, the LCR appears to affect the chromatin organization of the $\beta$-globin gene cluster which determines the chronological transcription of the individual genes during ontogenesis?

The $\alpha$-like globin gene cluster is found on the short arm of chromosome $\# 16$ and has three functional genes: the embryonic $\xi$ globin gene, the $\alpha 2$ and $\alpha 1$-globin genes (Figure 1.1). The synthesis of $\alpha$ - chains by both $\alpha 1$ and $\alpha 2$ genes differs only with respect to the rate of transcription and translation. Although the $\alpha 2$ gene has a more efficient transcription, the $\alpha 1$ gene has a more efficient translation, finally resulting in an almost equal production of $\alpha$-globin chains. Regulation of expression of the $\alpha$-globin genes is dependent on a region located $40 \mathrm{~kb}$ upstream. to the $\zeta$ gene, named HS- $40^{8}$.

The promoter region, about 100 nucleotides 5 to the transcription start site, is the element that initiates transcription by binding several transcription factors (TFIIA, B, C, D, E and TF-IIF) and the enzyme RNA polymerase II. It contains three nucleotide sequences that are found in all globin genes (TATA box, CAT box and CAC box $)^{7,4}$.

The $\beta$-globin genes also have enhancers that upregulate gene expression irrespective of their location relative to the target gene. They bind specific regulatory factors (Spl, GATA, NFE-2)7.9. In addition, silencer elements have been identified that contribute to a negative regulation of gene expression ${ }^{10,11}$. Processes such as DNA methylation and histon acetylation, that modificate DNA after its synthesis appear to influence the expression of globin genes as well ${ }^{12,13}$. 
$\beta$ Globin Locus - Chromosome 11

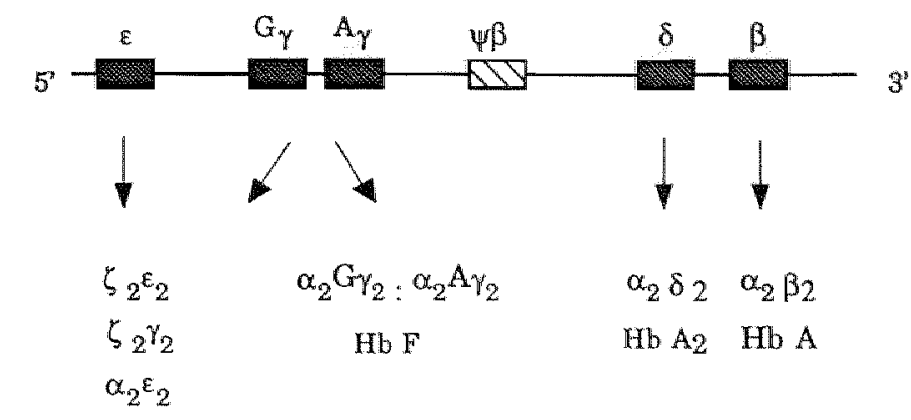

Embryonic Hb's Fetal Hb Adult Hb's

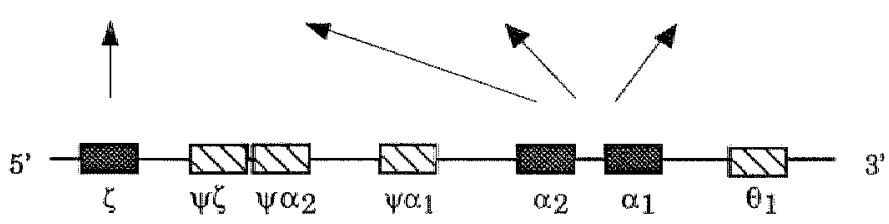

\section{$\alpha$ Globin Locus - Chromosome \# 16}

Figure 1.1 Organisation of the $\alpha^{-}$and $\beta$-globin gene clusters. Dark boxes represent functional genes.

The rate of synthesis, the tissue specificity, and the modulation of developmental globin gene expression are considered to be the result of interaction of promoter, enhancer and /or silencer elements with hypersensitive sites within the 5 ' regulatory region. Various nuclear proteins (or trans-acting factors) as mentioned above, interact with these motifs to regulate globin gene expression.

\section{Pathophysiology of sickle cell anemia}

The basic abnormality of hemoglobin $S$, which is the substitution of valine for glutamic acid at the sixth position in the $\beta$-chain, is the product of a single base mutation (GAG $\rightarrow$ GTG) at codon 6 of the $\beta$-globin gene $\left(\beta^{\mathrm{S}}\right)^{6}$.

The amino acid mutation of hernoglobin $S$ lies on the surface and normally causes little disturbance in the tetramer. However, especially in situations of low oxygen tension, it drastically changes the solubility of deoxygenated HbS. The $\beta 6$ valine molecules rapidly form hydrophobic bonds with complementary sites on $\beta$ subunits 
of other hemoglobin tetramers resulting in polymers or fibers made of large strands of tetramers. It has been shown that the rate of deoxygenation determines the shape and morphology of the red bllood cells (RBC). Rapid deoxygenation results in multiple independent polymerization events producing a granular texture that does not alter the cell's shape. In contrast, when SS RBC are partially or slowly deoxygenated a single core of hemoglobin strands is established which continues to aggregate and align more molecules until fibers are formed that characteristically distort the red blood cell to a sickle shape $\mathrm{A}^{14-16}$. The polymerization depends upon the concentration of HbS. In homozygous SS patients high levels of intracellular deoxygenated HbS lead to polymer formation whereas in heterozygotes (AS) the HbS level is usually insufficient to result in polymerization ${ }^{14,15}$. The polymerization process is time-dependent showing a delay time prior to actual gelation. Polymer formation and breakdown (sickling and unsickling) will occur repeatedly as a consequence of switching between the oxy and deoxy configuration of the $\mathrm{Hb}$ molecule. This eventually results in irreversible RBC membrane damage and deformation as well as perturbation of several other erythocyte properties which shorten red blood cell survival and promote vaso-occlusion ${ }^{14,15}$.

The vaso-occlusive episodes are thought to result from increased adhesive tendency of sickle reticulocytes and young deformable sickle cells to endothelium causing capillary blood flow to slow down, increasing transit time, metabolic acidosis, deoxygenation and consequently intracellular polymerization leading to more sickling and further loss of deformability of red cells. Entrapment of dense, rigid and undeformable, RBC follows and gives rise to complete capillary vasoocclusion ${ }^{17}$. The latter group of cells comprises the fraction of most dense and irreversibly deformed red cells which result from multiple sickling and unsickling episodes as well as a subset of cells with high occlusive affinity described as dense (high MCHC) discocytes ${ }^{18.19}$. These discocytes are rigid and change shape very little during oxygenation. Although the irreversible sickled cells have been demonstrated to correlate with the rate of hemolysis they do not show a relationship with the clinical symptoms of SS patients.

Several other factors influence the rate of sickling and/or the adhesion of sickle cells to venular endothelium. These include the intracellular $\mathrm{HbF}$ and 2,3-DPG levels, leakage of potassium across the red blood cell membrane with influx of sodium and calcium, the Von Willebrand factor (VWF), low oxygen tension, decreased $\mathrm{pH}$, increased temperature, advanced cell age, and increased intracellular $\mathrm{HbS}$ concentration ${ }^{2022}$.

\section{Prevalence and geographical distribution of $\mathrm{HbS}$}

There is evidence that the sickle cell trait provides some protection against Plasmodium falciparum malaria and this explains the preferential selection of the $\beta^{s}$ 
gene $^{23,24}$. In accordance, the geographical distribution of sickle cell disease coincides with areas where malaria is or has been endemic. The $\beta^{s}$ mutation probably took place in several locations in Africa and India millions of years ago. Today, sickle cell anemia is mainly found in Africa and among Afro-Americans in America and the Caribbean area. However, it is not limited to blacks. It is also encountered at lower frequencies in Southern countries of Europe, Eastern Europe, the middle east and India. In American blacks the frequency of HbS is approximately $8 \%$ and in Central Africa the frequency, depending on the area, may vary from 20 to $40 \%^{23.25}$.

\section{The $\beta^{\mathrm{S}}$ haplotype}

\section{Distribution of $\beta^{\text {s }}$-haplotypes}

While the $\beta^{S}$ mutation is common to all SS patients it apparently occurred several times independently on chromosomes of different genetic background ${ }^{25}$. Four specific $\beta$ haplotypes have been recognised which relate to different areas of Africa. They are the Benin haplotype (type 19) present in Central West Africa and North Africa (Nigeria, Benin, Ivory Coast,Ghana, Algeria, Sudan), the Senegal haplotype (type 3) originating from Atlantic West Africa (Senegal, Gambia, Liberia, Guinea), the Bantu haplotype (type 20) in South-Central and Eastern Africa (Angola, Zaire, Kenya, Namibia, Tanzania) and the Cameroon haplotype (type 17) which is mainly restricted to an ethnic group in Cameroon. A fifth haplotype, named the Asian (type 31), is encountered in Saudi Arabia and India ${ }^{25-31}$. The different $\beta^{S}$ haplotypes of patients in America and the Caribbean likely disclose the origins of their African predecessors ${ }^{23}$.

\section{Association of $\beta^{s}$-haplotypes with hematological and clinical data}

Although certain phenotypical differences have been noted between the haplotypes, a clear distinction has proven very difficult. Initial studies in Africa have been performed with small numbers of patients against a widely different environmental and genetic background. In developed countries, for example the United States, a predominant Benin haplotype is found together with a large group of heterozygous and atypical $\beta^{s}$ - haplotypes rendering only small numbers of other homozygous haplotypes available for study. Therefore clinical and hematologic effects of haplotype in sickle cell anemia should be interpreted with caution. Some characteristics of the four most common haplotypes are shown in table I.I. 
Table 1.1. Hematological and clinical manifestations in relation to the most common $\beta^{s}$-haplotypes.

\begin{tabular}{lcccc}
\hline & $\begin{array}{c}\text { BENIN } \\
(\mathbf{1 9 / 1 9 )}\end{array}$ & $\begin{array}{c}\text { BANTU } \\
(\mathbf{2 0 / 2 0 )}\end{array}$ & $\begin{array}{c}\text { SENEGAL } \\
(\mathbf{3} / \mathbf{3})\end{array}$ & $\begin{array}{c}\text { ARAB- } \\
\text { INDIAN } \\
(\mathbf{3 1 / 3 1})\end{array}$ \\
\hline $\begin{array}{l}\text { Hemoglobin } \\
\text { HbF }\end{array}$ & $\downarrow$ & $\downarrow \downarrow$ & $\downarrow$ & $\downarrow$ \\
$\begin{array}{l}\text { Painfull crises } \\
\text { End organ }\end{array}$ & $\uparrow \uparrow$ & $=$ & $\uparrow \uparrow$ & $\uparrow \uparrow \uparrow$ \\
damage & $\uparrow$ & $\uparrow \uparrow *$ & $\uparrow$ & $\uparrow$ \\
\hline
\end{tabular}

$=$ : not increased. "In particular high incidence of renal failure; "* Rarely priapism and leg ulceration; acute chest syndrome less frequent.

\section{Diagnosis}

Sickle cell anemia may be suspected on clinical grounds and the patient's hematologic profile (complete bloodcount, reticulocyte count and examination of peripheral blood smear). The presence of HbS may be confirmed by a sickle cell solubility test. This test relies on the fact that $\mathrm{HbS}$ precipitates in high osmolarity phosphate buffer at neutral $\mathrm{pH}$ when reduced with sodium hydrosulphite while normal Hb's do not precipitate ${ }^{32}$. The test is not useful in the newborn period because of the high amount of $\mathrm{HbF}$ within the red blood cells. A more accurate method of HbS detection is the immunologic procedure which is based on binding of antibody to the $\beta 6$ Glu $\rightarrow$ Val replacement. ${ }^{33}$.

The quantification of HbS, confirmation of sickle cell anemia and differentiation of $\mathrm{HbS}$ from other Hb types can be done by $\mathrm{Hb}$ electrophoresis, Isoelectric Focusing or by High Performance Liquid Chromatography (HPLC).

The $\mathrm{Hb}$ electrophoresis, usually in an alkaline medium (cellulose acetate), is the conventional method of confirming sickle cell anemia. The method relies on the migration of the negatively charged hemoglobin molecule towards the anode in an electrical field. The abnormal $\mathrm{Hb}$ has a different charge than $\mathrm{Hb} \mathrm{A}$ and the two can be differentiated on the basis of their different mobilities in the electrical field. It remains popular because the method is simple, however, it fails in differentiating HbS from other Hb's (such as HbD) which show similar mobilities ${ }^{32}$. 
Isoelectric Focusing (IEF) produces superior resolution of hemoglobins by fractionating proteins according to their isoelectric points along a $\mathrm{pH}$ gradient in an agar or polyacrylamide ge ${ }^{34}$. In addition to detection of conditions like AS, SS, $A C, A D$ and $A G$, more complicated combinations such as a $\beta$ chain variant and a $\alpha$ chain variant are readily identified. In most centres IEF is the preferred procedure for newborn screening since the method clearly separates $\mathrm{HbF}$ from other minor quantities of adult Hbs.

HPLC, a technically more difficult as well as expensive type of chromatography, allows separation of hemoglobins through application of cation exchange resin column. Three different methods are used ${ }^{35-37}$ : 1. Cation exchange HPLC for separation of HbS. 2. Reversed phase HPLC for separation of globin chains and 3. Another type of reversed phase HPLC for the separation of fragments of globin chains obtained by proteolytic digestion. The technique provides an excellent resolution of the different hemoglobins and is useful in distinguishing the various forms of sickle cell disease (SS, SC, S- $\beta$-thal, and other rarer types). The HbF level as well as each of the different $\gamma$-chain levels can be accurately determined.

DNA analysis has enabled us to specify the molecular pathology of the different haemoglobinopathies. After isolating DNA from white blood cells, the DNA segment to be studied is amplified and sequenced, using synthetic oligonucleotide probes that hybridize specifically with the normal and mutated sequences ${ }^{38,39}$. This technique enables identification of haplotypes of the $\beta^{s}$-globin gene and is now also used for prenatal diagnosis.

\section{Clinical features of sickle cell disease}

Infants before the age of 6 months do not show any sign of disease due to the predominance of $\mathrm{HbF}$. However, as soon as the HbF level starts to decrease and the intracellular $\mathrm{HbS}$ concentration rises, symptoms of anemia and hemolysis follow.

One of the earliest signs of intravascular sickling in children is the hand-foot syndrome (dactylitis), a painful swelling of the hands and feet due to ischaemic inflammation ${ }^{40}$. The clinical picture of the older SS patients is dominated by hemolytic anemia and recurrent vaso-occlusive episodes or crises. However, there exists an enormous variability in the clinical symptoms between individual patients. Also, the clinical features tend to change in the same SS individual during time.

The most common clinical manifestations are the painful crises. They are episodes of severe pain involving vaso-occlusion of marrow and or bone microcirculation ${ }^{41}$. 
There are no specific laboratory findings in vaso-occlusive- or pain crisis. Diagnosis is based on clinical symptonatology. Pain episodes occur mostly in the extremities and the backbone, are often symmetrical and usually start in one place and extend distally. Pain events are rather stereotypical for a particular patient i.e. they occur frequently in the same site(s) and many times with the same sequence. Some patients suffer repeated acute and severe pain episodes on a background of chronic pains. Patients with a higher leucocyte count suffer more frequent painful episodes. The frequency and severity of these pain crises greatly influence a patient's quality of life. Although painful crises can occur at all ages, they are particularly common during adolescence, and between the ages of 20 and 40 years. After the third decade the rate of painful episodes decreases sharply which may be the result of bone marrow fibrosis due to recurrent infarctions ${ }^{41}$.

The acute chest syndrome (ACS), comprising chest pain, cough, fever and dyspnea with abnormal clinical and radiological chest signs, may be caused by a spectrum of infection, infarction, pulmonary sequestration of sickle red cells and fat embolism. The ACS may progress to a respiratory distress syndrome which places it among the commonest causes of death in adolescent and adult SS patients. Recurrent attacks of ACS may result in pulmonary fibrosis and chronic sickle cell lung disease ${ }^{42,43}$.

Renal disease in young sickle cell patients is dominated by occlusion and infarction of vasa recta in the renal medulla. Earlier studies have shown that the tubular function becomes compromised and the potential to build up a high medullary interstitial solute concentration, necessary for urinary concentration, is gradually lost resulting in hyposthenuria ${ }^{44.45}$. By the age of 15 all SS patients express hyposthenuria. The medullary ischemia also stimulates synthesis of renal prostaglandins which explains the increased glomerular filtration rate and effective renal blood flow found in patients under 40 years ${ }^{46.47}$. Hematuria is accasionally seen due to micro-infarction of renal pyramids ${ }^{27}$. As patients grow older renal blood flow and glomerular filtration rate tend to decline due to progressive glomerular sclerosis, tubular damage, infections and renal infarction (either by local vaso-occlusion or emboli from necrotic bone marrow) in some cases leading to renal insufficiency and dialysis ${ }^{4 *}$.

Heart failure may occur as a consequence of chronic hypertrophy of the myocardium in very anemic older sickle cell patients ("high output" cardiomyopathy), or due to hemochromatosis of the heart secondary to multiple transfusions. Myocardial infarction due to sickling is highly unusual which is explained by the short transit time of red blood cells across the coronary system. Sickle cell vaso-occlusion of the myocardium resulting in cardiomyopathy has 
never been demonstrated ${ }^{23}$.

Sequestration crises are the result of massive trapping of erythrocytes in either spleen, liver or lungs. Sequestration in spleen or liver is clinically recognised by painful swelling of the organ with a significant decrease in hemoglobin level ${ }^{27.49}$. The pain involved with liver sequestration crisis may give rise to confusion since it sometimes resembles other causes of the acute (right) abdomen. The liver sequestration presents a serious condition which may progress to fulminant hepatic failure and death. The spleen is particularly sensitive to recurrent vaso-occlusion, infarction and the sequestration phenomenon, which usually take place during the first 10 years of life. The organ gradually becomes fibrotic, regresses in size and its function is lost.

\section{Infections}

Sickle cell patients have a compromised immune system due to functional asplenia or splenic involution. Consequently, SS patients have a greater propensity for bacterial infections (and septicemia) in particular by Pneumococcus, Hemophilus influenza type b, Escheria coli and Salmonella spp. Interestingly, young SS patients with co-existent $\alpha$-thalassemia have been shown to maintain a normal splenic function $^{50}$.

Other factors that add to the immunocompromised state of the SS patient are defecis in complement system, granulocyte and B cel function. The cellular immunity may be diminished due to iron overloading by frequent transfusions ${ }^{27,49}$.

Aplastic crises, caused by the destruction of erythrocyte precursors by human parvovirus infection may also complicate sickle cell disease. These attacks are characterized by a sudden decrease in hemoglobin (which falls by about. I g/dl per day) with few or no reticulocytes ${ }^{27.49}$. As long as adequate oxygen delivery to tissues is maintained by transfusions the outcome is good. The failure of erythropoiesis is self-limiting and bone marrow recovery usually starts after 7-10 days of aplasia.

Hyper-hemolytic crises are also recognised but many, in particular in younger individuals, may be due to splenic sequestration crises. Other hyper-hemolytic episodes usually accompany infections. Due to chronic hemolysis SS patients often reveal jaundice and many of them develop gallstones at a relatively young age ${ }^{49}$.

Priapism resulting from blockage of the corpus cavernosum by sickle cells preventing the necessary outflow of blood from the penis, may be a particularly difficult problem. Many male patients when specifically questioned admit experiencing brief episodes of painfull erections (stuttering attacks) which resolve 
spontaneously. Major attacks of sustained erection for more than 24 hours almost invariably result in loss of penile erective function ${ }^{27}$.

Bone complications. Aseptic bone necrosis, especially of the femur but also of the humerus head, occurs in up $1030 \%$ of SS patients and occasionely leads to invalidity. Osteomyelitis is known to result from secondary infection of bone infarcts or avascular necrosis. Until recently, Salmonella has been considered to be the main causative organism, but, new evidence now shows a preponderance of Klebsiella and Staphylococcus Aureus ${ }^{27.49,51}$.

Leg ulcers are common to SS individuals between 15 and 50 years and are almost always located at the medial side of the ankle. The leg ulcers may or may not occur in relation to trauma and are the consequence of skin infarction, poor woundhealing and poor granulation. They are seen more frequent in males. Individuals who experienced a leg ulcer are known to have a much greater risk for a new leg ulcer ${ }^{52}$.

Eye manifestations. Ischemia due to vaso-occlusion may damage several tissues of the eye. In general the most common serious ocular complications arise from retinal small vessell and capillary occlusion and neovascularization ${ }^{5_{3}}$.

The central nervous system (CNS). Vaso-occlusive complications in the CNS system may vary from transient features such as speech, visual or hearing disturbances to permanent hemiplegia and death from stroke. Stroke occurs mostly in children and, similar to the leg ulcer, tends to re-occur in the same individual ${ }^{27}$. Recurrence may be prevented by regular bloodtransfusions ${ }^{\text {st }}$.

Multiorgan failure, which may complicate a period of recurrent painfull episodes, presents a desperate clinical situation. It is probably caused by widespread fat embolization of extensive infarction and necrosis of bone marrow ${ }^{55}$.

Pregnancy. During pregnancy, progesteron induced smooth muscle relaxation with slowing down of blood flow and increased levels of coagulation factors (in particular fibrinogen), provoke sickling and result in an increase in vaso-occlusive complications. Delivery presents extra risks due to stress, haemoconcentration, acidemia, hypotension (blood-loss) and hypoxemia ${ }^{56}$.

Mortality. Average life expectancy of male sickle cell patients is 42 years, while females reach the average age of 48 years. Mortality correlates strongly to the number of painful episodes per year. This fact is also corroborated by the observation that adult SS patients in developed countries frequently die under 
circumstances of hospitalization for severe and recurrent painful crises $^{57}$.

Univariate analysis of laboratory parameters has revealed that early mortality correlates directly with leucocyte and alkaline phophatase levels and inversely with total hemoglobin and fetal hemoglobin ( $\mathrm{HbF}$ ) levels. Especially high $\mathrm{HbF}$ levels are associated with superior life expectancy ${ }^{57.58}$.

\section{Determinants of clinical severity of sickle cell disease}

Among patients, disease expression varies enormously and varies in the same individual from time to time. As clearly shown in a large colsort study in the United States, the clinical course is highly influenced by specific organ damage sustained by SS patients during the years ${ }^{59}$. The differences in clinical disease result from a great variety of genetic, vascular, plasma, red blood cell and environmental properties (Table I.2).

Table 1.2. Factors that may contribute to sickle cell vaso-occlusion

HbS polymer

Sickle cell deformability

Sickle blood viscosity

Fraction of dense, irreversibly sickled cells

Sickle cell endothelial cell adhesion

Hemostatic activation

Platelets

White blood cells and cytokines

Vascular condition (anatomy, blood flow, endothelial condition; vaso active peptides)

The nervous system responses and environmental influence

\section{Genetic factors}

In addition to the crucial $\beta^{s}$ mutation itself, other genetic variables or epistatic effects) such as regulators of the $\mathrm{HbF}$ level, total hemoglobin level and concomittant $\alpha$ - thalassemia influence the level of disease severity.

- HbF modulating factors. Elevated $\mathrm{HbF}$ is associated with a milder disease manifestation due to the formation of a soluble hybrid with $H b S\left(\alpha 2 \gamma \beta^{S}\right)$ which inhibits polymerization. At the molecular level this effect is explained by the presence of a glutamine residue at $\gamma 87$ position which prevents a critical lateral contact in the double strand of the sickle fiber ${ }^{60}$.

Among others, specific mutations at the level of the promotor regions of the $\gamma$ genes have been found to explain the differences in $\mathrm{HbF}$ levels and disease severity 
between different haplotypes ${ }^{61-63}$. Patients with the Asian and Senegal haplotype carry high $\mathrm{HbF}$ (15-30\%) which is known to contribute to a less severe clinical outcome. Those with the Benin and Bantu type have lower HbF levells and reflect a more severe disease course ${ }^{64-69}$. Mutations described within the Locus Control Region of the $\beta^{s}$ chromosome also influence $\mathrm{HbF}$ levels and thereby may alter the phenotypical expression of disease ${ }^{63,70}$. Recently, the X-linked F-Cell Production (FCP) locus has been discovered ${ }^{71}$, which appears to be an even more important determinant of the level of $\mathrm{HbF}$.

- Henoglobin level and whote blood cells. The average hemoglobin level and packed cell volume of an individual patient being the result of several factors, is also known to influence the clinical disease state. High total hemoglobin raises viscosity of blood and is a risk factor for painful crises ${ }^{72}$, chest syndrome, hip necrosis and proliferative retinopathy ${ }^{73}$. An elevated leucocyte count appears to be a risk factor for stroke ${ }^{74}$, chest syndrome ${ }^{75}$ and death in SS patients ${ }^{58,59}$.

- Concomittant $\alpha$-thalassemia. The combination of $\alpha$-thalassemia (caused by deletion of either one or two genes) and the HbS homozygote produces microcytosis and a lower intra-erythrocytic concentration of HbS (lower MCHC values). Alpha thalassemia is also accompanied by increase in $\mathrm{HbA}_{2}$ which is probably caused by greater affinity of the limited $\alpha$ chains for $\delta$ chains rather than for $\beta^{s}$ chains. The lower $\mathrm{MCHC}$ and higher $\mathrm{HbA}_{2}$ reduce the chance of polymer formation and intravascular sickling. The hemolytic rate is reduced and deformability of red cells is improved. The acute chest syndrome and leg ulceration are less common in SS - $\alpha$-thal. There is no reduction in frequency of painful crises $^{76,77}$.

\section{Vascular and plasma factors}

Young deformable sickle red cells adhere to vascular endothelial cells much more than irreversibly sickled cells (ISC). Ballas et all. ${ }^{78}$ have shown that there exists a significant positive correlation between red blood cell deformability and the frequency and severity of painful crisis. Deformable sickle cells may cause direct damage to endothelial cells and cause narrowing of the blood vessel lumen with consequent sludging or trapping of ISC and rigid dense cells resulting in vasoocclusion. The interaction with endothelium also causes alterations in the levels of vaso-active peptides and other mediators ${ }^{79.85}$. Exposure of human endothelial cells in culture to sickled erythrocytes resulted in a significant transcriptional induction of the gene encoding the vasoconstrictor endothelin- $\rfloor^{81}$. Simultaneously, a suppression of transcripts, encoding the protein responsible for nitric oxide synthesis, was documented in the endothelial cells. Normal or unsickled sickle cells exposed to the same conditions had no effect on endothelin gene induction. 
Imbalances in substances like nitric oxide, prostacyclins, platelet derived growth factor, endothelin and free oxygen radicals, all interacting with endothelium or with its direct environment, can cause local vasospasm or failure of vasodilatory mechanisms and contribute to sickle cell crises and organ damage ${ }^{82}$. On the other hand, the iocal microvascular complications may cause adaptive mechanisms to take effect. One such possibly adaptive mechanism, the periodic capillary flow, has been revealed by the use of Laser -Doppler vellocimetry ${ }^{\text {s.3 }}$. In studies using this technique it has been observed that the microcirculatory flow in SS patients increases periodically. This results in increased perfusion pressure, which may help to restore the flow in plugged capillaries.

Sickle cells as well as endothelial cells both express surface molecules that mediate intercellular adhesion (Figure I.2). Studies indicate that the CD 36 and the group of very late activation(VLA-4) receptors, also referred to as the $\alpha 4 \beta 1$ integrin receptors of the erythrocyte membrane, are specifically involved in endothelial adhesion $^{84.85}$. On the endothelial side the integrin $\alpha v \beta 3$ and vascular adhesion molecule-1 appear to play a specific role in the interaction with red blood cells. Immature reticulocytes show the greatest expression of adhesion receptors and this decreases as the cells become more mature ${ }^{86.87}$. Several cytokines (i.e. TNF- $\alpha$, IL-1 and IL-6), when induced by external factors such as microorganisms or toxins may enhance expression of endothelial adhesion receptors, activate leucocyles (i.e. IL-8), the complement system and coagulation, and stimulate production of acute phase proteins ${ }^{88-90}$. Certain plasma proteins (so-called ligand proteins) may augment sickle cell-endothelial adhesion by acting as bridging molecules between the abovementioned receptors. Among these proteins are fibrinogen, thrombospondin, von Willebrand factor multimers and fibronectin ${ }^{91-94}$. In addition, thrombospondin also binds to sulphated glycans on SS red cells ${ }^{95}$. Fibronectin (FN) is a large glycoprotein dimer which may be found in plasma as well as in the interstitium. Il's main source of production are the hepatocytes (for the plasma FN), fibroblasts, macrophages and endothelial cells (for the cellular FN). Fibronectin contains multiple binding sites for cell membrane integrins, fibrin, collagen and heparin ${ }^{96}$.

\section{Red blood cell properties}

In addition to the abovementioned factors, the increased red blood cell turnover and hematopoietic stress cause changes in the circulating erythroid progenitors (BFU-E). Their number increases, they react more sensitive to cytokines and their capacity to proliferate increases ${ }^{97}$.

An effect which does not appear to be specifically related to young erythrocytes, is the enhanced oxidative stress within red blood cells, which probably results from an increase in methemoglobin formation and reduction. The oxidative stress damages cytoskeletal proteins which causes cell rigidity and alters transport proteins $^{27}$. 


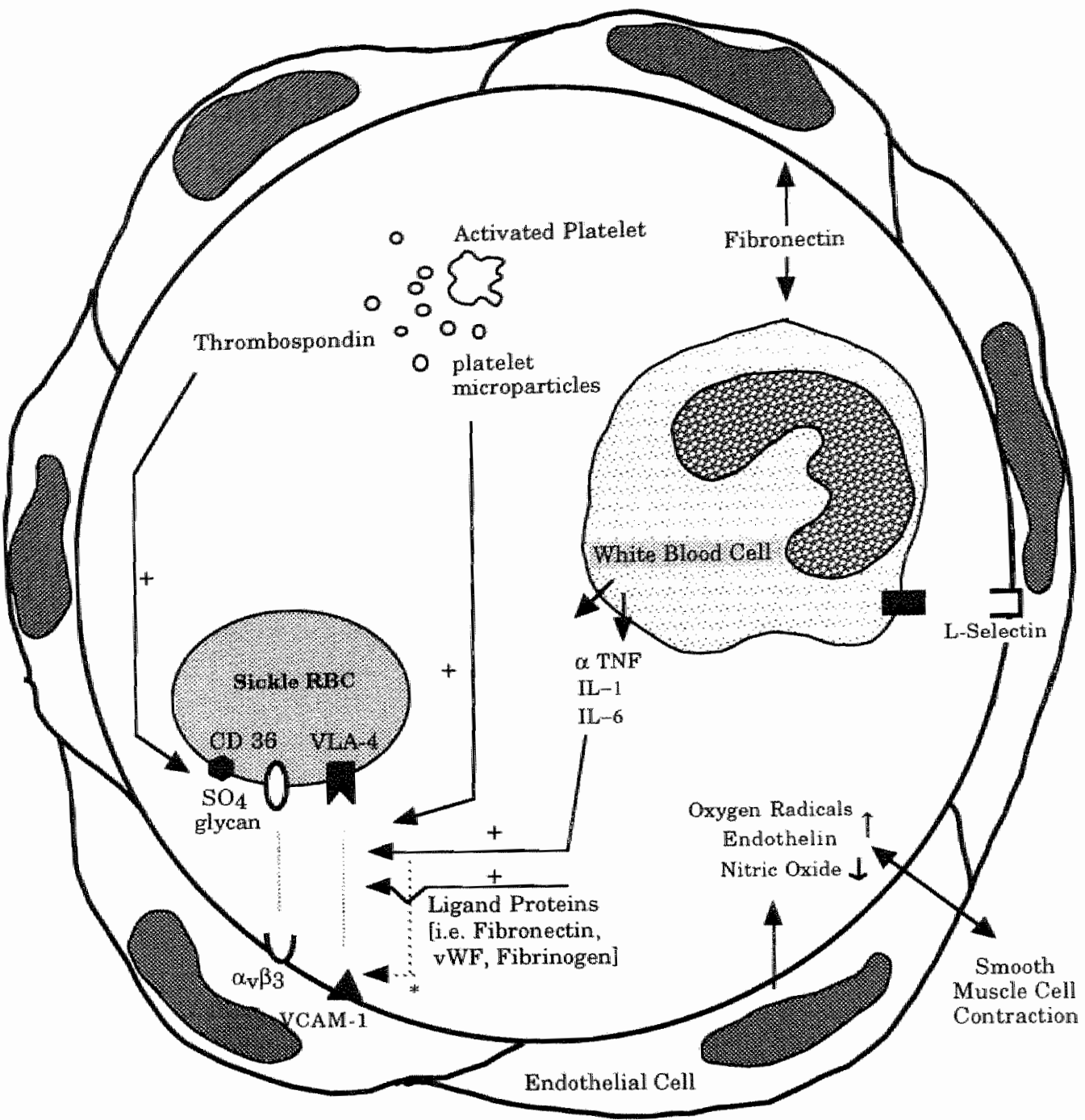

Figure 1.2 Vascular factors and cellular mechanisms involved in adhesion of biood cells to endothelium and vatso-occlusion. * Receptor up-regulation by cycokines.

It has also been shown that abnomalities in composition and function of phospholipids (sulfated glycans) in the membrane of the sickle cell serve as a target for macrophage recognition, may cause complement activation or express procoagulant activity (binding of thrombospondin) and could therefore influence the vaso-occlusive processes ${ }^{95,98,99}$. 
Patients with associated red blood cell G-6-PD deficiency may be more at risk for repeated hemolytic crisis ${ }^{100}$.

Red blood cell volume alterations, as in SS - $\alpha$-thal or acquired because of a concomittant vitamin deficiency or iron loss, as well as by changes in hydration statu ${ }^{101}$, also modulate disease severity.

\section{Leucocytes}

Since leucocyte numbers correlate well with early montality in sickle cell disease and the severity of sickle cell crisis ${ }^{5 *}$ "it is conceivable that abnormal leucocyteendothelial cell adhesion plays a role in the pathogenesis of the vaso-occlusive crisis. Indeed, during sickle cell crisis increased adhesive properties of leucocytes have been observed in addition to the commonly noted leucocytosis ${ }^{102-104}$. Also, Hofstra et al. ${ }^{\text {ws }}$ have shown that polymorphonuclear leucocytes may be activated as a result of specific sickle $R B C$ binding via an $\operatorname{lgG}$-mediated process. Leucocytes could initiate a vaso-occlusive crisis in two ways (Figure I.2): Either mechanically block the capillary system, especially when the vascular bed is already constricted or partially obstructed by adherent red cells, or adhere to venous or capillary endothelium through specific leucocyte-endothelial ligand-receptor interactions (i.e. fibronectin) $)^{96.103 .104 .106}$. With respect to the latter mechanism, it has also been shown that hypoxia promotes white blood cell adhesion to endothelium, prior to any ischemic tissue damage ${ }^{107}$. The adhered and/or obstructing leucocytes inhibit blood flow and oxygen delivery to the tissues and may release cytokines which activate many other cells giving way to massive intravascular sickling and ischemic tissue damage. Furthermore, activated leucocytes could traverse the endothelial border, releasing inflammatory mediators and oxygen radicals in the interstitium, causing significant deterioration of tissue inflammation and ischemic damage ${ }^{108}$.

\section{Platelets}

Thrombocytosis is common to sickle cell crisis, but is also seen in steady state. The trombocytosis has been attributed to the progressive splenic infarction ${ }^{109}$. In addition to thrombocytosis a marked increase in circulating platelet aggregates and platelet factors (such as thrombospondin, $v W F$ and $\beta$-thromboglobulin) have been observed in the steady state ${ }^{92.94,110}$. Platelets, being thus readily activated, may enhance sickle red cell binding to endothelium (Figure 1.2). Although hypothetically individual differences in platelet activity could result in differences in severity of disease, this remains to be proven clinically.

\section{Environmental factors}

There are various environmental factors that have their influence on the severity of disease. They are not only responsible for differences in disease expression 
between individuals, but also may modulate disease in the same individual. One of the most important environmental factors that may induce painfull crises is cold temperature as shown by a study performed in Jamaica ${ }^{41}$. Among the other factors are malaria (in particular in many tropical areas), proper health care, nutrition, intake of folic acid and the iron levels. Nutrition promotes growth and strengthens the immune system. Folic acid protects against megaloblastic changes ${ }^{111}$. A low iron level inhibits $\mathrm{HbS}$ polymerization by lowering the mean cell hemoglobin concentration (MCHC) and may actually ameliorate some aspects of sickle cell disease $^{1: 2}$.

\section{Sickle cell trait}

In comparison to the homozygous SS patients, the red blood cells of the heterozygous AS individuals carry approximately $45 \% \mathrm{HbS}$. The AS individual usually does not exhibit sickling, is asymptomatic and has a normal life expectancy. However, under extreme conditions i.e. a combination of hypoxemia, hypotension acidosis and slowing down of blood flow, sickling may occur. This is particularly true for the renal medulla where the sluggish blood flow and hypertonic environment promote sickling in the vasa recta. Therefore AS individuals may develop renal abnormalities during the years. Also, occasionally splenic infarction has been observed at high altitudes ${ }^{27,113}$. Sudden death occurs more frequently in persons with sickle cell trait and has particularly been described in military recruits exposed to heavy exertion and heat stress ${ }^{14}$. Sickle cell trait confers protection for malaria. Individuals with the sickle trait show reduced mortality from Plasmodium Falciparum infection probably due to early elimination of infected sickle cells from the bloodstream ${ }^{82}$.

\section{Treatment}

\section{Therapy for acute crises}

Painful crises are usually treated empirically with hydration and analgesics. Due to the extreme character of the pain morphin is often administered. Oxygen is frequently administered, but not routinely indicated except in the setting of hypoxemia or cardiopulmonary disease. Simple transfusion is commonly used to treat life-treatening situations although good evidence for its use is difficult to obtain. Retrospective analysis and uncontrolled data indicate that in multiorgan failure as well as stroke and chest syndrome in children, transfusions to low levels
of $\mathrm{HbS}$ (approxis of $\mathrm{HbS}$ (approximately $30 \%$ ) are associated with increased chance of 
survival $^{95.115-119}$. Some studies have shown a beneficial effect of transfusion in lessening the severity of vaso-occlusive crises ${ }^{15,16}$. A study comparing conservative versus aggressive preoperative tranfusion showed no differences in outcome except for an increase in transfusion related adverse events in the group of aggressively transfused patients ${ }^{120}$. The $\mathrm{Hb}$ levels aimed at with tranfusion may be too high since a $\mathrm{Hb}$ level in excess of $8 \mathrm{~g} / \mathrm{dl}$ may result in hemodynamic and rheological deterioration ${ }^{121}$.

Red blood cell exchange transfusion offers advantages over simple transfusion such as eliminating the risk of volume overload and increase in viscosity and reducing the chance of iron overload. It's major role is in the management and for prevention of life or organ-threatening events. Based on information from numerous anecdotal reports in the past decade it is now recommended for deteriorating chest syndrome, acute or impending vascular episodes, hepatic or multisystem failure and retinal arteriolar vaso-occlusion ${ }^{18}$.

The most significant reduction of the mortality rate in sickle cell anaemia over the past decades has been achieved due to the advent of antibiotic treatment. Treatment of vaso-occlusive episodes that may involve infection should include early application of antibiotics.

\section{Therapies directed at prevention}

Several drugs have been tried over the years in an attempt to reduce the rate of vaso-occlusive episodes in SS patients. Based on the beneficial effects of $\mathrm{HbF}$ on HbS polymerization agents such as hydroxyurea, butyrate analogues and erythropoietin have been administered. The effects of these agents as well as the results of hydroxyurea therapy and isobutyramide are discussed in detail in the next chapters of this thesis.

- Drugs with antisickling effect. Antimycotic agents, such as clotrimazole, have demonstrated the ability to inhibit sickling in mice, by lowering corpuscular $\mathrm{Hb}$ through inhibition of calcium activated loss of $\mathrm{K}^{+}$through the Gardos channel in the erythrocyte membrane ${ }^{122}$. Oxygen affinity increasing products are also under investigation ${ }^{23}$. Combinations of the latter agents are expected to be studied clinically in the near future ${ }^{124}$. During the past two decades many other agents that were claimed to be of benefit in the treatment of sickle cell anemia, either due to an antisickling effect or by promoting capillary flow, were studied (pentoxyfylline, cetiedil, piracetam, dicoumarol, aspirin, calcium antagonists and defibrinating agents). The beneficial effects of most of these agents were not confirmed in controlled trials ${ }^{125} \cdot 34$. For some, the data from ongoing controlled trials are not yet available. 
- Allogenic bone marrow transplantation in sickle cell disease is feasible and may be curative in young patients with severely symptomatic sickle cell disease ${ }^{135-139}$. However, some patients reject the marrow allograft and the sickle cell disease reoccurs. Mortality of the procedure still carries a risk of $10 \%$ as well as a risk of infertility. Furthermore, data on the induction of malignancies by high dose chemotherapy, involved in ablation of bone marrow before transplantation, are not yet available ${ }^{140}$.

- Gene therapy. Addition of a normal $\beta$ gene into the genome of the haemopoietic stem cell of the SS patient is considered by many as the golden standard of treatment. Researchers have been able to transfer the human $\beta$-globin gene with the LCR region to erythroid cells, using recombinant adeno-associated virus as a vector ${ }^{141}$. The newly transduced cells showed an accurate regulation of human globin expression. Although these techniques have not reached beyond the level of the laboratory, they may become feasible in clinical practice in the near future.

- Intervention in blood cell-endothelium interactions. The growing insight into pathophysiologic mechanisms of adhesion of different blood cells to endothelium may offer new possibilities to directly reduce or prevent vaso-occlusive events $^{142,143}$. 


\section{References}

1. Herrick JB. Peculiar elongated and sickle -shaped red blood corpuscles in a case of severe anemia. Arch Intern Med. 1910;6:517.

2. Pauling L, liano HA, Singer SI, Wells IC. Sickle cell anemia, a molecular disease. Science 1949: 110: 543.

3. Ingram VM. A specific chemical difference between the hemoglobins of normal human and sickle cell anemia hemoglobin. Nature 1956; 178: 792.

4. Ingram VM. Gene mutations in human hemoglobin: the chemical difference between normal and sickle cell hemoglobin. Nature 1957; 180: 326.

5. Ingram VM. How do Genes act ? Sci Am 1958; 198: 68.

6. Huisman THJ. The structure and function of normal and abnormal haemoglobins. In The Haemoglobinopathies, edited by D.J. Weatherall and D.R. Higgs, Balliere's Clinical Haematology, Vol. 6, W.B. Saunders Company, London, 1993.

7. Curtin P. Kan YW. Sickle Cell Disease: The molecular genetics of hemoglobin, In: Whitten $\mathrm{C}$ and Bertles J, eds. Annals of the New York Academy of Sciences. 1989; 565: $1-12$.

8. Higgs DR, Vickers MA, Pretorius I-M, Jarman AP, Weatherall DJ. A review of the molecular genetics of the human $\alpha$-globin gene cluster. Blood $1989 ; 73: 1081$,

9. Nienhuis AW, Maniatis T. Structure and expression of globin genes in erythroid cells. In: The Molecular Basis of Blood Diseases, edited by G. Stamatoyamopoulos, A.W. Nienhuis, P. Leder and P.W. Majerus. W.B. Saunders Company, Philadelphia, 1987.

10. Raich N, Papayannopoulou Th, Stamatoyannopoulos G, Enver T. Demonstration of a human e-globin gene silencer with studies in transgenje mice. Blood 1992; 79: 861.

11. Berg PE, Mittelman M, Elion J, Labie D, Schechter AN. Increased protein binding to a -530 mutation of the human $\beta$-globin gene associated with decreased $\beta$-globin synthesis. Am J Hematol 1991:36: 42.

12. Ploeg van der LH, Flavell RA. DNA methylation in the human $\gamma$, $8-, \beta$-globin locus in erythroid and nonerythroid tissues. Cell 1980; 19:947.

13. Felsenfeld $\mathrm{G}$. Chromatin as an essential part of the transcriptional mechanism. Nalure $1992 ; 355: 219$.

14. Noguchi CT, Schechter AN. The intracellular polymerization of hemoglobin and its relevance to sickle cell disease. Blood 1981; 58: 1057-1068.

15. Eaton WA, Horichter J. Hemoglobin S gelation and sickle cell disease. Blood 1987 ; 70: $1245-1266$.

16. Asakura T, Mattiello JA, Obata K. Parthally oxygenated sickled cells: sickle-shaped red cells found in circulating blood of patients with sickle cell disease. Proc Natl acad Sci USA 1994; $91: 12589 \ldots 12593$.

17. Nagel RL. Sickle cell anemia is a multigene disease: Sickle painful crises, a case in point. Am I Hematol 1993; 42: 96-101. 
18. Kaul DK, Fabry ME, Windisch P. Baez S. Erythrocytes in sickle cell anemia are heterogeneous in their theological and hemodynamic characteristics. I Clin Invest 1983; 72: 22-31.

19. Kaul DK, Fabry ME, Nagel RL. Vaso-occlusion by sickle cells: ewidence for selective trapping of dense red cells. Blood 1986; 68: 1162-1166.

20. Kaul DK, Nagel RL. Sickle cell vaso-occlusion: Many issues and some answers. Experientia 1993; 49: 65.

21. Ueda $Y$. Bookchin RM. effects of carbon diaxide and pH variations in vitro on blood cell volume, transmembrane $\mathrm{pH}$ gradients and sickling in sickle cell anemia. J Lab Clin Med 1984; 104: 146.

22. Vitoux DO, Olivieri RP, Garay EJ. Inhibition of $\mathrm{K}^{+}$efflux and dehydration of sickle cells by l(dihydroindenyl) oxyl alkanoic acid: An inhibitor of the $K^{*} \mathrm{Cl}$ cotransport system. ProcNatl Acad Sci, USA 1989; 86: 4273.

23. Nagel RL, Ranney HM. Genetic epidemiology of structural mutations of the $\beta$ globin gene. Semin Hematol $1990 ; 27: 342-349$.

24. Allison $\mathrm{AC}$. Protection afforded by sickle cell trait against subtertian malaria infection. Br Med I 1954; i: 290.

25. Nagel RL. Origens and dispersion of the sickle gene. In: Sickle Cell Disease- Basic Principles and Clinical Practice, edited by Embury SH, Hebbel RP, Mohandas N, Steinberg MH, page 353-380, Raven Press Ltd, New York, 1994.

26. Pagnier J, Mears JG, Dunda-Belkhodja O, Schaefer-Rego KE, Beldjord C, Nagel RL, Labie D. Evidence for the multicentric origin of the sickle cell hemoglobin gene in Africa. Proc Natl Acad Sci USA, 1984; 81: 1771- 1773.

27. Serjeant GR. Sickle cell disease 2nd edition, Oxford University Press, 1992.

28. Wainscoat IS, Bell II, Thein SL, Higgs DR, Serjeant GR, Peto TEA, Weatherall D). Multiple origens of the sickle mutation: evidence from $\beta^{s}$-globin gene cluster polymorphisms. Mol Biol Med 1983; 1: 191-197.

29. Nagel RL, Fabry ME, Pagnier I, Zohoun I, Wajcman H, Baudin V, Labie D. Hematologically and genetically distinct forms of sickle cell anemia in Africa; the Senegal type and the Benin type. N Engl J Med 1985; 312:880-884.

30. Bakioglu I. Hathori $Y$, Kutlar A. et al. Five adults with mild sickle cell anemia share a beta* S chromosome with the same haplotype. Am J Hematol 1985; 20 : $297-300$.

31. Dimovski Al. Factors affecting the fetal hemoglobin levels in patients with sickle cell anemia and thalassemia. Thesis, University of Limburg, Maastricht, The Netherlands 1993, p 37.

32. Huisman THJ, Jomxis JHP. The Hemoglobinopathies Techniques of Identification, Cinical and Biochemical Analysis, Vol 6, Marcel Dekker Inc., New York, 1977.

33. Epstein N, Epstein M. Boulet A, Fribach E, Rodgers $G$. Flow cytometric analysis of RBCs from pacients with sickle cell anemia treated with hydroxyurea with respect to the expression of sickle and fetal hemoglobins. Seventh Annual Meeting, Clinical Application of Cytometry, sept. 1992, Charleston SC, Abstract 53, page 65-66. 
34. Righetri $\mathrm{PG}$, Gianazza $\mathrm{E}$, BianchimBosisio $\mathrm{A}$, Cossu $\mathrm{G}$. Conventional isoelectric focusing and immobilized pH gradients for hemoglobin separation and identification. In Huisman THI (ed): "The Hemoglobinopathies". Vol 15. Edinburgh: Churchill Livinstone, $1986, \mathrm{p} 47$.

35. Shelton JR, Shelton JB, Schroeder WA. High performance liquid chromato-graphic separation of globin chains on a large-pore $\mathrm{C}_{4}$ column. $\mathbb{l}$ liq Chromatogr 1984; 7 : $1969-1977$.

36. Bisse $\mathrm{E}$, Wieland $\mathrm{H}$. High performance liquid chromatographic separation of human haemoglobins: Simultaneous quantitation of foetal and glycated haemoglobins. I Chromatogr 1988;434: 95-110.

37. Huisman THJ, Kutlar F, Gu L-H. $\gamma$ chain abnormalities and $\gamma$-globin gene rearrangements in newborn babies of various populations. Hemoglobin, 1991; 15: 349.

38. Saiki RK, Scharf S, Faloona F, Mullis KB, Horn GT, Erlich HA, Arnheim N. Enzymatic amplification of $\beta$-globin genomic sequences and restriction site analysis for diagnosis of sickle cell anemia. Science 1985; 230: 1350 .

39. Sambrook J, Fritsch EF, Maniatis T. Molecular Cloning, A Laboratory Manual, Cold Spring Harbor Laboratory Press, Cold Spring Harbor, 1989.

40. Stevens MCG, Padwick M, Serjeant GR. Observations on the natural history of dactylitis in homozygous sickle cell disease. Clin Pediat 1981; 20:311-317.

41. Serjeant GR, De Ceulaer C, Lethbridge R, Morris J, Singhal A, Thomas PW. The painful crisis of homozygous sickle cell disease: Clinical features. Br J Haematol 1994; $87: 586-591$.

42. Haupt HM, Moore GW, Bauer TW and Hutchins GM. The lung in sickle cell disease. Chest $1982 ; 81: 332 \times 337$.

43. Van Agtmael MA, Cheng JD, Nossent HC. Acute chest syndrome in adult AfroCaribbean patients with sickle cell disease. Ann Intern Med 1994; 154 (5): 557-561.

44. Statius van Eps LW, Pinedo-Veels C, De Vries GH, and De Koning J. Nature of concentrating defect in sickle cell nephropathy. Microradio- angiographic studies. Lancet 1970; i: 450-451.

45. Stalius van Eps LW, Schouten H, Ter Haar Romeny-Wachter CH and La PorteWijsman LW. The relation between age and renal concentration capaciry in sickle cell disease and hemoglobin C disease. Clin Chim Acta 1970; 27:501-511.

46. de Jong PE, de Jong-van den Berg LTW, Sewrajsingh GH, Schouten H, Donker AJM, and Statius van Eps LW. The influence of indomethacine on renal hemodynamics in sickle cell anemia. Clin Sci 1980; 59:245-250.

47. de Jong PE, Saleh AW, de Zeeuw D, Donker AJ, van der Hem GK, Prall JJ, Sewrajsingh GH, Statius van Eps LW. Urinary prostaglandins in sickle cell nephropathy: a defect in 9-keto-reductase activity. Clin. Nephrol 1984; 22:21-23.

48. Morgan AG, Serjeant GR. Renal function in patients over 40 with sickle cell disease. Br Med J 1981;282: 1181-1183.

49. Higgs DR, Weatherall DJ. The Haemoglobinopathies. In Clinical Haematology. international practice and research 1993, Bailliere Tindall: Vol 6/No 1. 
50. Adekile AD, Tuli M, Haider MZ, Al-Zaabi K, Mohannadi S, Owunwanne A. Influence of $\alpha$-thalassemia trait on spleen function in sickle cell anemia patients with high HbF. Am J Hematol 1996; 53: 1-5.

51. Aken'Owa YA, Bakare RA, Okunade MA, Olaniyi J. Bacterial causes of acute osteomyelitis in sickle cell anemia: changing infection profile. West Afr I Med 1995; 14: $255-258$

52. Koshy M, Entsuah R, Koranda A, et al. Leg ulcers in patients with sickle cell disease. Blood 1989; 74: 1403-1408.

53. Van Meurs JC. Ocular findings in sickle cell disease on Curaçao. Thesis, University of Nijmegen, The Netherlands, 1990.

54. Cohen AR, Martin MB, Silber JH, Kim HC, Frempong KO, Schwartz E. A modified transfusion program for prevention of stroke in sickle cell disease. Blood 1992; 79: 1657-1661.

55. Hassell KL, Eckman JR, Lane PA. Acute multiorgan failure syndrome: a potentially catastrophic complication of sickle cell pain episodes. Am J Med 1994; 96: 155162.

56. Landman H. Haemoglobinopatties and Pregnancy. Doctoral Thesis, University of Groningen, Groningen, The Netherlands, 1988.

57. Platt OS, Brambilla DJ, Rosse WF, Milner PF, Castro O, Steinberg MH, Klug PP. Mortality in sickle cell disease: Life expectancy and risk factors for early deatl. N Engl J Med 1994; 330: 1639-1644.

58. Leikin SL, Gallagher D, Kinney TR, Sloane D, Klug P, Rida W, and Cooperative Study of Sickle Cell Disease: Mortality in children and adolescents with sickle cell disease. Pediatrics 1989; 84: 500-508.

59. Powars DF, Schroeder WA. Progress in the Natural History Studies of the clinical severity of Sickle Cell Disease: Epidemiologic aspects. In Biochemical and Clinical Aspects of Hemoglobin Abnormalities, Academic Press Inc, 1978; 151-163

60. Nagel RL, Bookchin RM, Johnson J. Structural bases of the inhibitory effects of hemoglobin $\mathrm{F}$ and hemoglobin $\mathrm{A} 2$ on the polymerization of themoglobin $\mathrm{S}$. Proc Natll Acad Sci USA 1979; 76: 670-672.

61. Hattori $Y$, Kutlar F, Kutlar A, Mc Kie VC, Huisman TH. Haplotypes of $\beta^{\text {s. }}$ chromosomes among patients with sickle cell anemia from Georgia. Hemoglobin 1986; 10: 623-642.

62. Oner $\mathrm{C}$. Dimovski AJ, Olivieri $\mathrm{NF}$ et al. $\beta^{\mathrm{S}}$ Haplotypes in various world populations. Hum Genet 1992; 89: 99-104.

63. Dimovski AJ. Factors affecting the fetal hemoglobin levels in patients with sickle cell anemia and thalassemia. Doctoral Thesis, University of Limburg, Maastricht. The Netherlands, 1993.

64. Perrine RP, Pembrey ME, John $\mathbb{P}$, Perrine $S$, Shoup F. Natural history of sickle cell anemia in Saudi Arabs: a study of 270 subjects. Ann Intern Med 1978;88:1-6.

65. Nagel RL, Erlingsson S, Fabry ME, Croizat H, Susuka SM, Lachman H, Sution M, Driscoll C. Bouhassira E, Billett HH. The Senegal DNA haplotype is associated with the amelioration of anemia in Atrican-American sickle cell anemia patients. Blood 1991; 77: 1371-1375. 
66. Nagel RL, Fabry ME, Pagnier J. Zohoun I, Wajoman H, Baudin V, Labie D. Hematologically and genetically distinct forms of sickle cell anemia in Africa: the Senegal type and the Benin type. N Engl J Med 1985; 312:880-884.

67. Green NS, Fabry ME, Kaptuenoche L. Nagel RL. The Senegal haplotype is associated with higher HbF than Benin and Cameroon haplotypes in African children with sickle cell anemia. Am J Hematol 1993; 44: 145 146.

68. Nagel RL, Rao SK, Dunda-Belkodja O. Connolly MM, Fabry ME, Georges A, Krishnamoorthy $\mathrm{R}$, Labie $\mathrm{D}$. The hematological characteristics of sickle cell anemia bearing the Bantu haplotype: The relationship between $\gamma$ and Hemoglobin $F$ levels. Blood 1987: 69: $1026-1030$.

69. Powars DR, Meiselman HJ, Fisher TC, Hiti $A$, Johnson $C$. Beta-S gene cluster haplotypes modulate hematologic and hemorheologic expression in sickle cell anemia: use in predicting clinicall severity. Am J Pediatr Henatol Oncol 1994; 16: 55-61.

70. Oner C, Dimovshi AJ, Altay C, Gurgey A, Gu YC, Huisman "THJ, Lanclos KD. Sequence variations in the $5^{\circ}$ hypersensitive site-2 of the locus control region of $\beta^{\circ}$ chromosomes are associated with different levels of fetal globin in HbS homozygotes. Blood 1992; 79: 813-819.

71. Chang YC, Smith KD, Moore RD, Serjeant GR, Dover GJ. An analysis of fetal hemoglobin variation in sickle cell disease: The relative contributions of the $X$ linked factor, $\beta$-globin haplotypes, a-globin gene number, gender and age. Blood 1995; 85: $1111-1117$.

72. Platt OS, Thorington BD, Brambilla DJ, Milner PF, Rosse WF, Vichinsky $E$, Kinney TR: Pain in sickle cell disease. Rates and risk factors. N Engl J Med 1991: 325: $11-16.35$.

73. Serjeant GR. Natural history and determinants of clinical severity of sickle cell disease. Current opinion in Hematology 1995; 2: 103-108.

74. Balkaran B. Char G, Morris JS, Thomas PW, Serjeant BE, Serjeant GR. Stroke in a cohort of patients with homozygous sickle cell disease. I Pediatr 1992: 120:360366.

75. Castro O, Brambilla DJ, Thorington B, Reindorf CA, Scott RB, Gilette P, Vera JC, Levy PS, and the cooperative Study of Sickle Cell Disease: The acute chest syndrome incidence and risk factors. Blood 1994; 84: 643-649.

76. Stemberg $\mathrm{MH}$, Rosenstock W, Coleman MB, et al. Effects of thalassemia microcytosis on the hematologic and vaso-occlusive severity of sickle cell anemia. Blood 1984; 63: 1353-1360.

77. Embury SH, Dozy AM, Miller J, Davis JR, Kleman Km, Preisler H, Vichinsky E, Lande WN, Lubin BH, Kan YW, Mentzer WC. Concurrent sickle cell anemia and alpha thalassemia: effect on severity of anemia. N Engl J Med 1982; 306:270-274.

78. Ballas SK, Larner J, Smith E. Surrey S, Schwartz E, Rappaport EF. Rheological properties of sickle erythrocytes in the steady state predict the frequency and severity of the sickle cell painful crisis. Ann NY Acad Scil 1989; 565; 364 365. 
79. Hebbel RP. Boogaert MAB, Eaton JW. Stemberg MH. Erythrocyte adherence to endothelium in sickle cell anemia: a possible determinate of disease severity. $N$ Engl Med 1980: 302: $992-995$.

80. Mohandas $\mathrm{N}$, Evans $\mathrm{E}$. Adherence of sickle erythrocytes to vascular endothelial cells: Requirement for both cell membrane changes and plasma factors. Blood 1984: 64: $282-287$.

81. Phelan M, Perrine SP, Brauer M, Faller DV. Sickle erythrocytes, after sickling, regulate the expression of the endothelin-1 gene and protein in human endothelial cells in culture. J Clin Invest 1995; 96: 1145-1151.

82. Embury SH, Hebbel RP, Mohandas N, Steinberg MH. Sickle Cell Disease, basic principles and clinical practice 1994, page 217-246, by Raven Press Lid, New York, 1994.

83. Rodgers GP, Schechter AN, Noguchi CT, Klein HG, Nienhuis AW, Bonner RF. Periodic microcirculatory flow in patients with sickle cell disease. N Engl J Med 1.984; $311: 1534-1538$.

84. Wick TM, Eckman JR, Kumar A, Jeitler M, Swerlick RA. Reticulocytes from patients with sickle cell anemia express the $\alpha 4 \beta 1$ integrin complex and bind to the TNF- $\alpha$ activated endothelial cells via VCAM-1/ $\alpha \beta 1$ dependent mechanism. Blood 1992; 80: (supp\|1): 11a (Abstract).

85. Swerlick RA, Eckman JR, Kumar A, Jeitler M, Wick TM. $\alpha 4 \beta$ I- integrin expression on sickle reticulocytes: Vascular adhesion molecule-1-dependent binding to endothelium. Blood 1993; 82: 1891-1899.

86. Simith BD, LaCelle PL. Erythrocyte-endothelial cell adherence in sickle cell disorders. Blood 1986; 68: 1050-

87. Kaul DK, Fabry ME, Nagel RL. Microvascular sites and characteristics of sickle cell adhesion to vascular endothelium in shear flow conditions: Pathophysiological implicalions. Proc Natl Acad Sci (USA) 1989;86:3356-3360.

88. Konkle BA, Shapiro SS, Asch AS, Nachman RL. Cytokine-enhanced expression of glycoprotein Iba in human endothelium. J Biol Chem 1990; 265: 19833-19838.

89. Sowemino-Coker $S$. Haywood LJ. Meiselman HJ, Francis RB jr. Interleukin-1 increases adtherence of normal and sickle erythrocytes to endothelial cells. Blood 1989; 74 (suppl): 313 a (abstr).

90. Vordermeier S, Singh S, Biggerstaff I Harrison P, Grech H, Pearson TC, Dumonde DC, Brown KA. Red blood cells from patients with sickle cell disease exhibit an increased adherence to cultured endothelium pretreated with tumor necrosis factor (TNF). Br J Haematol. $1992 ; 81: 591-597$.

91. Juneja HS. Pathophysiology and management of sickle cell pain crisis. Lancet 1995; 346: $1408-1411$.

92. Antonucci R, Walker R, Herion J, Orringer E: Enhancement of sickle erythrocyte adherence to endothelium by autologous platelets. Am J Hematol 1990; 34: 44-48.

93. Sugihara K, Sugihara T, Mohandas N, Mosher D. Hebbel RP. Thrombospondin at pathophysiologic levels mediates adherence of CD 36-positive sickle reticulocytes to endothelial cells. Blood 1992; 80|suppl]: 344 a (abstract). 
94. Brittain HA, Eckman JR, Swerlick RA. Howard RJ, Wick TM. Thrombospondin from activated platelets promotes sickle erythrocyte adherence to human microvascular endothelium under physiologic flow: a potential role tor platelet activation in sickle cell vasomocclusion. Blood 1993: 81:2137-2143.

95. Hillery CA, Du MC. Montgomery RR, Scot JP. Increased adhesion of erythrocytes to components of the extracellular matrix: isolation and characte- rization of a red blood cell lipid that binds thrombospondin and laminim. Blood 1996: 87: 4879 4886.

96. Kasschau MR, Barabino GA, Brdiges KR, Golan DE. Adhesion of sickle neutrophils and erythrocytes to fibronectin. Blood 1996;87: 771-780.

97. Croizat. Early circulating erythroid progenitors (BFU-E) in sickle cell anemia. Experientia $1993 ; 49: 118-125$.

98. Lubin BH, Kuypers FA, Chiu D. Sickle cell disease: Lipid alterations and cellular properties of sickle red cells. In: Whitten $\mathrm{C}$ and Bertles J eds. Annals of the New York Academy of Sciences. 1989; 565: 86-96

99. Wang RH, Phillips $\mathrm{G}$ jr, Medof ME, Mold C. Activation of the alternative complement pathway by exposure of phosphatidylethanolamine and phospham tidylserine on erythrocytes from sickle cell disease patients. J Clin Invest 1993; 92: $1326-1335$

100. Smits HL, Oski FA, Brody JI. The hemolytic crisis of sickle cell anaemia: The role of G-6-PD deficiency. J Pediatr, 1969; 74:544.

101. Canessa M, Fabry ME, Blumenfeld $N$, Nagel RL. A volume-stimulated, Cldependent $\mathrm{K}+$ efflux is highly expressed in young human red cells containing normal hemoglobin or HbS. J Memb Biol 1987; 97: 97.

102. Buchanan GR, Glader BE. Leucocyte counts in children with sickle cell disease. Am J Dis Child 1978; 132: 396-398

103. Lachant NA, Oseas RS. Case report: vaso-occlusive crisis associated with neutrophil dysfunction in patients with sickle cell disease. Am J Med Sci 1985; 294 : 253-257.

104. Boghossian SH, Wrigh G, Webster DB, Segal AW. Imvestigations of host defenses in patients with sickle cell disease. Br J Haematol 1985; 59: 521-523.

105. Hofstra TC, Kalra VK, Meiselman HJ, Coates TD. Sickle erythrocytes adhere to polymorphonuclear neutrophils and activate the neutrophil respiratory burst. Blood $1996 ; 87: 771-780$.

106. Lipowsky HH, Chien S. Role of leucocytemendothelium adhesion in affecting recovery from ischemic episodes. Ann NY Acad Sci 1989; 565: 308-3\|4.

107. Ginis I. Menzer SJ, Faller DV. Low oxygen tension induces neutrophit adhesion to human endothel al cells via an LFA-1-dependent mechanism. If Cell Ploysiol 1993: 167: $569-578$.

108. Till GO, Johnson KJ, Kunkel R, Ward PA. Intravascular activation of complemeni and acute lung injury: Dependency on neutrophils and toxic oxygen metabolites. J Clin Invest 1982; 69: 1126-1135.

109. Kenny MW. George AJ, Stuart J. Platelet hyperactivity in sickle cell disease: A consequence of hyposplenism. J Clin Pathol 1980; 33:622-625. 
110. Westwick I. Watson-Williams EI. Krishnamurhi S. Platelet activation during steady state stckle cell disease. I Med 1983: 14:17-36.

11. Heyman $M B$, Vichinsky $E$, Katz $R$, Gaftield $B$, Hurst $D$, Castillo $R$, Chiu $D$, Keman $K$. Ammann Ad, Thaler MM, Lubin B. Growh retardation in sickle cell disease treated by nutritional support. Lancet 1985; i: 903-906.

12. Castro O, Poillon WN, Finke H, Massac E, Kim BC. Improvement of sickle cell anemia by iron-limited erythropoiesis. Am J Hematol 1994; 47:74-81.

113. Sears DA. The morbidity of sickle cell trait. A review of the literature. An J Med 1978; 64: 1021-1036.

14. Kark JA, Posey DM, Schumacher HR, Ruehle CI. Sickle cell trait as a risk factor for sudden death in physical training. $N$ Engl I Med 1987; 317: 781-787.

115. Styles LA, Vichinsky EP. Effects of a long-term transfusion regimen on sickle cellrelated illnesses. I Pediat 1994; 125: $909-911$.

116. Sarmaik S, Soorya D, Kim J, Ravindranath $Y$, Lusher J. Periodic rransfusions for sickle cell anemia and CNS infarction. Am J Dis Child 1979; 133: 1254-1257.

117. Davies SC, Luce PJ, Winn AA, Brozovic M. Acute chest syndrome in sickle cell disease. Lancet 1984; i: 36-38.

I18. Wayne AS, Kevy SV, Nathan DG. Transfusion management of sickle cell disease. Blood 1993; 81: 1109-1123.

119. Anderson R, Cassell M, Mullinax G, Chaplin H. Effect of normal cells on the viscosity of sickle cell blood. Arch Intern Med 1963; 111: 286-294.

120. Vichinsky EP. Haberkern CM, Neumayr $\mathbb{L}$, Earles AN, Black D, Koshy M, Pegelow C, Abboud M, Ohene-Frempong K, lyer RV, Preoperative Transfusion in Sickle Cell Disease Study Group. A comparison of conservative and aggressive transfusion regimens in the perioperative management of sickle cell disease. N Engl J Med 1995; 333: 206-2 13 .

121. Schmalzer EA, Lee JC. Brown AK, Usami S, Chien S. Viscosity of mixtures of sickle cells and normal red celis at varying hematocrite levels implications for uransfusion. Transtusion $1987 ; 27: 228-233$.

122. De Franceschi L, Sadane N, Trudel M. Alper SL, Brugnara C. Beuzard Y. Treatment with oral clotrimazole blocks $\mathrm{Ca}(2+)$-activated $\mathrm{K}+$ transport and reverses erythrocyte dehydration in transgenic SAD mice. J Clin Invest 1994; 93; $1670-1676$.

123. Abrahan DJ, Mehanna AS, Wireko FC. Whitney J, Thomas RP. Orringer EP. Vanillim, a potential agent for the treatment of sickle cell anemia. Blood 1991; 77: 1334-1341.

124. Stuart J, Mojminiyi FB, Stone PC, Culliford SJ, Ellory JC. Additive in vitro effects of anti-sickling drugs. Br J Haematol 1994: 86: 820-823.

125. Ambrus JL. Ambrus CM. Gastpar H. Bannerman R, Bettigole R, Friedman $S$. Sudies in vaso-occhusive crisis of sickle cell disease. Effect of pentoxifylline. I Med 1979: $10: 445-450$.

126. De Ceulaer K, Serjeant GR. Nagel RL. Billet HH, Christakis J, Loukopoulos D. Bellingham A.l, Lucas GS, Stuart J. Intravenous pentoxifylline and the painfull crisis of sickle cell disease. Clin Hemorheol 1990; 10: 35-42. 
127. Benjamin LJ, Berkowiz LR, Orringer E, Mankad VN, Prasad AS, Lewkow LM, Chillar RK. Peterson CM. A collaborative, double blind randomized study of Cetiedil citrate in sickle cell crisis. Blood 1986; 67: 1442-1447.

128. Johnson MN, Ellory JC, Stuart J. Bepridil protects sickle cells against the adverse

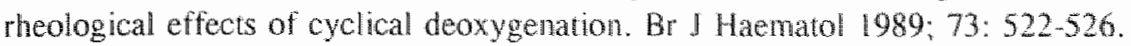

129. Targino de Araujo J, Nero GS. Piracetam and acetamide in sickle cell disease. Lancet 1977 ; ii: 411 .

130. Salwaggio JE, Arnold CA, Banov CH. Long-term anticoagulation in sickle cell disease. N Engl J Med 1963; 269: 182-186.

131. Haddock DRW, Konotey-Ahulu FID, Janosi M, Ankra-Badu G, Reid HA. Thrombosis in sickle cell pain crisis? Controlled trial of ancrod (Arvin) in young adults. J Trop Med Hyg 1973; 76: 274-278.

132. Greenberg J, Ohene-Frempong K. Halus J, Way C, Schwartz E. Trial of low doses of aspirin as prophylax is in sickle cell disease. J Pediatr 1983;102: 781-784.

133. Gini EK, Sonnet J. Use of piracetam improves sickle cell deformability in vitro and in vivo. J Clim Pathol. 1987; 40: 99-102.

134. Rodgers GP, Roy MS, Noguchi CT, Schechter AN, Is there a role for selective vasodilation in the management of sickle cell disease ? Blood 1988; 71: 597-602.

135. Johnson FL, Look AT, Gockerman J, Ruggiero MR, Dalla Pozza L. Billings FT III. Bone matrow transplantation in a patient with sickle-cell anemia. $\mathrm{N}$ Engl J Med 1984; $311: 780-783$.

136. Ferster A, De Valck C, Azzi N, Fondu P, Toppet M, Sariban E. Bone marrow transplantation for severe sickle cell anemia. Br J Haematol 1992; 80: 102-105.

137. Johnson FL, Mentzer WC, Kalinyak KA, Sullivan KM, Abboud MR. Bone marrow transplantation for sickle cell disease: The United States experience. Am I Pediatr Hematol Oncol 1994; 16:22-26.

138. Vermylen C, Cornu G. Bone marrow transplantation for sickle cell disease: The European experience. Am J Pediatr Hematol Oncol 1994; 16:18-21.

139. Watters MC, Patience M, Leisenuing W, Eckman I, Scott IP, et al. Bone marrow transplancation for sickle cell disease. N Engl J Med 1996; 335: 369-376.

140. Plat OS, Guinan EC. Bone marrow transplamtation in sickle cell anemia the dilemma of choice (editorial). N Engl J Med 1996; 335: 426-428.

141. Einerhand MPW, Antoniou M, Zoloturkhin S, Muzyezka N, Berns F. Grosveld F. and Valerio. D. Regulated high level human $\beta$-globin gene expression in erythroid cells following $\mathrm{r}$ AAV-mediated gene transfer. Abstract, 20 th Annual Meeting of the National Sickle Cell Disease Program, Boston 1995, p 19.

142. Solovey $A$, Lin $Y$, Browne P, Choong $S$, Wayner $E$, Hebbel RP. Circulating activated endothelial cells in sickle cell anemia. N Engl J Med 1997; 337: 1584-90.

143. Bunn HF. Mechanisms of Disease: Pathogenesis and Traetment of Sickle Cell Disease. N Engl 』 Med 1997; 337; 762-70. 


\section{Chapter II}

\section{Sickle cell disease in Curaçao}

AW Saleh 


\section{Introduction}

Sickle cell anemia in Curaça was first described in 1943 by van der Sar. He abserved the case of a pregnant woman with this disease. Over the past decades, many studies have provided data on morbidity and mortality of local sickle cell anemia as well as data on pathophysiological aspects of the disease. In the fifties and sixties, research produced valuable epidemiological data and investigations on the properties of the abnormal hemoglobin ${ }^{1-6}$. Studies in the seventies and eighties affered new insights into the pathophysiology of sickle cell nephropathy ${ }^{7-19}$ as well as information on calcium, lipids, fatty acids and trace elements in sickle cell anemia $a^{20.23}$. In the past ten years, several studies have been published on clinical aspects of the disease in Curaçao, such as ocular findings ${ }^{24}$ and the acute chest syndrome $^{25}$; new data on the incidence of hemoglobinopathies have been reported ${ }^{26.27}$ and research has focused on the pathophysiology of adhesive mechanisms, which seem to play an important role in sickle cell vaso-occlusion ${ }^{28-32}$. Moreover, several therapies have been tried in an attempt to improve the symptoms of the disease ${ }^{33}$. 37 .

\section{Epidemiological aspects}

\section{SS and SC disease}

The population of Curaçao, like many other islands in the Caribbean, is predominantly black, originating mainly from the west coast of Africa. The number of patients with sickle cell disease (SS $+\mathrm{SC}$ ) in Curaçao has been estimated through studies by van der $\operatorname{Sar}^{2}$, Jonxis ${ }^{3}$, van $\operatorname{Zanen}^{4}$, and more recently by Muskiet and van der Dijs ${ }^{26.27}$. In the latter study, during three months, $67.2 \%$ of all (748) newborns were screened for their hemoglobin pattern. The authors report a $\beta^{s}$ gene frequency of 0.0258 and a $\beta^{c}$ gene frequency of 0.0347 . The 1tb AS incidence was found to be $4,6 \%$. Considering an island population of 145.000 and applying the appropriate equations $\left(\left[\beta^{\mathrm{s}} \text { gene frequency }\right]^{2} \times\right.$ population no.) for SS patients and ( $\beta^{\mathrm{S}}$ gene frequency $\times \beta^{\mathrm{C}}$ gene frequency $\times 2 \times$ population no.) for SC patients, an estimate prevalence of 100 SS patients and 260 SC patients may be reached. The actual number of SS patients will be lower due to the shorter life span of these patients. Compared to the most common $\mathrm{Hb} S$ regions in Africa where the proportion of $\mathrm{Hb} S$ carriers is over $15 \%$, the percentage of Hb S carriers in Curaçao is relatively low. The discrepancy may be explained by 2 reasons:

1. Racial admixture. This was first brought about by mingling of European plantation owners with black female slaves. Thereafter, at the beginning of the 20 th century, immigrants of other nations were attracted to the island by the oil refinery and also mixed to some degree with the black population. One could speculate on a further decrease of the local Hb $S$ carriers in view of the recent 
increase in immigration of biack individuals to the Netherlands.

2. The absence of malaria in Curacao.

It has beon shown that, in areas endemic for malaria, the frequency of sickle cell carriers (trait) is higher ${ }^{3}$. Their survival rate is increased compared to healthy individuals because they develop malaria less often and less severe. Consequently, in the absence of malaria, the sickle cell trait will not be positively selected and its frequency will be lower.

The relative high prevalence of $\mathrm{SC}$ disease is explained by the predominant descent of the population from West Central Africa (Ghana/Gold Coast) where a relative high frequency of $\mathrm{Hb} \mathrm{C}$ is found ${ }^{2}$. In general, data from the black population of other islands in the Caribbean are rather similar to that from Curaçao, although some areas in Jamaica and Surinam show proportions for $\mathrm{Hb} \mathrm{S}$ carriers similar to Africa due to the presence of malaria. Moreover, the SC frequency in the region is somewhat lower which may be explained by the fact that the ancestry came from different parts of Africat ${ }^{2,3,39}$.

\section{Sickle cell -lhalassemia disease}

With respect to the presence of thalassemia van Zanen ${ }^{4}$ was the first to document so-called non-classical thalassemia among $\mathrm{Hb} \mathrm{S}$ carriers in Curaçao. This form of expression of thalassemia was later ascribed to $\alpha$-thal-2 which is ypical for the African population. In their study Muskiet and van der Dijs ${ }^{26.27}$ estimate that $4,1 \%$ had either $\mathrm{Hb} \mathrm{S}$ or $\mathrm{Hb} \mathrm{C}$ with 8,1

$\alpha$-thalassemia-2. These findings are in general agreement with data from the AfroAmerican population in the region and the United States with the exception of some population groups in Jamaica and Surinam that carry the $\alpha$-thal-1 type deletion which is typical of their Asiatic background.

Data from African areas with a high $\beta^{\text {s }}$ gene frequency reveall a low prevalence of $\beta$-thalassemiat . Similarly, only small numbers of patients with sickle cel - $\beta$-thal have been reported among Jamaicans of West African origen ${ }^{4}$. So far no attempt has been made to detect compound heterozygotes for HbS and $\beta$-thalassemia in Curaçao.

A rew other hemoglobin variants and compound $\mathrm{Hb} S$ heterozygotes have been incidentally documented but a discussion of these is not within the scope of this thesis.

\section{Age and sex distribution}

Before the sixthes the average life-span of SS patients was reported to be 20 years. The average age of the SC patient was longer and approached that of normal individuals which lead to the conchusion that SC disease was much more benign than SS disease. During the recent years no new local data have been acquired. However, the Cooperative Study of Sickle Cell Disease in the USA has estimated 
that $85 \%$ of SS patients now live beyond the age of 20 years compared with $50 \%$ two decades ago:2. This most likely holds true for Curaçao since compared to the USA, equivalent advances in health care (antibiotics, education, improved supportive measures) have been established during the past two decades. Data on sex distribution in sickle cell disease in Curaçao are very limited. The frequency of the male sickle cell trait has been shown to be consistently higher than that of the female when looking at their local distribution as well as in the region or Surinam ${ }^{2,4}$. Recent data from africa indicate that these differences occur mainly during teenage years ${ }^{43}$. The explanation for this discrepancy remains unclear.

\section{$\beta^{s}$-Haplotype distribution in Curaçao}

Prior to the studies performed in this thesis no information was available on the

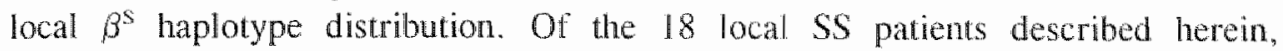
thirteen had their $\beta^{s}$ haplotype and $\alpha$-gene number determined (Table 11,1). All patients were SS individuals registered at the outpatient clinic for internal medicine. The $\beta^{S}$ haplotypes were determined by Dot-Blot DNA hybridization analysis ${ }^{44}$ and the $\alpha$-globin genotypes were anallysed by screening for the $-\alpha(3.7 \mathrm{~kb})$ deletion using a modified polymerase chain reaction method ${ }^{45}$. Fourtheen patients revealed the Benin haplotype or type 19/19. Two carried hybrid haplotypes (Benin/Bantu or $19 / 20$ and Benin/Senegal or 19/3). One patient had a combination of sickle cell anemia with $\alpha$-thalassemia. She revealed a relatively low MCV and MCHC which explain the less severe hemolysis typical of co-existent $\alpha$-thal. Another patient was a carrier of the $\alpha$-thalassemia trait $(-\alpha / \alpha \alpha)$. Because of her relatively high $\mathrm{Hb} \mathrm{F}$ level this patient was also assumed to have some type of deletional hereditary persistence of fetal hemoglobin (HPFH). The finding that the majority are of the Benin haplotype is consistent with historical facts. In the 17 th and 18 ih century Curaçao was a center trough which slaves from Africa were distributed over neighbouring countries. Most slaves in Curaçao originated from Ghana, the Gold Coast and neighbouring countries which regions are typical for the Benin haplotype (Figure II. 1). Accordingly, it has also been shown that the most common haplotype in Surinam, another former dutch colony in the region, is the Benin haplotype ${ }^{46}$.

\section{Clinical SS disease in Curaçao}

Tables II.1 to II.3 summarize the clinical picture as well as the laboratory data of 18 SS patients during a period of ten years prior to the studies performed in this thesis. Clinical data were collected by studying the patient's records at the policlinic for internal medicine and at the medical archive of the St. Elisabeth Hospital. Patients were also requested in an interview to give a summary of their complaints and complications during the past 10 years. The specific data that were 
looked at included the number of painful crises, pulmonary and renal complications, priapism, bone complications, leg ulceration, eye problems, hemochromatosis, and complicarions related to pregnancy.

All patients showed signs of hemolytic anemia with hemoglobin levels varying from $4.5 \mathrm{~g} \%$ to $9.6 \mathrm{~g} \%$ with increased $\mathrm{LDH}$. Overall, individuals with high fetal hemoglobin experienced a less complicated clinical course.

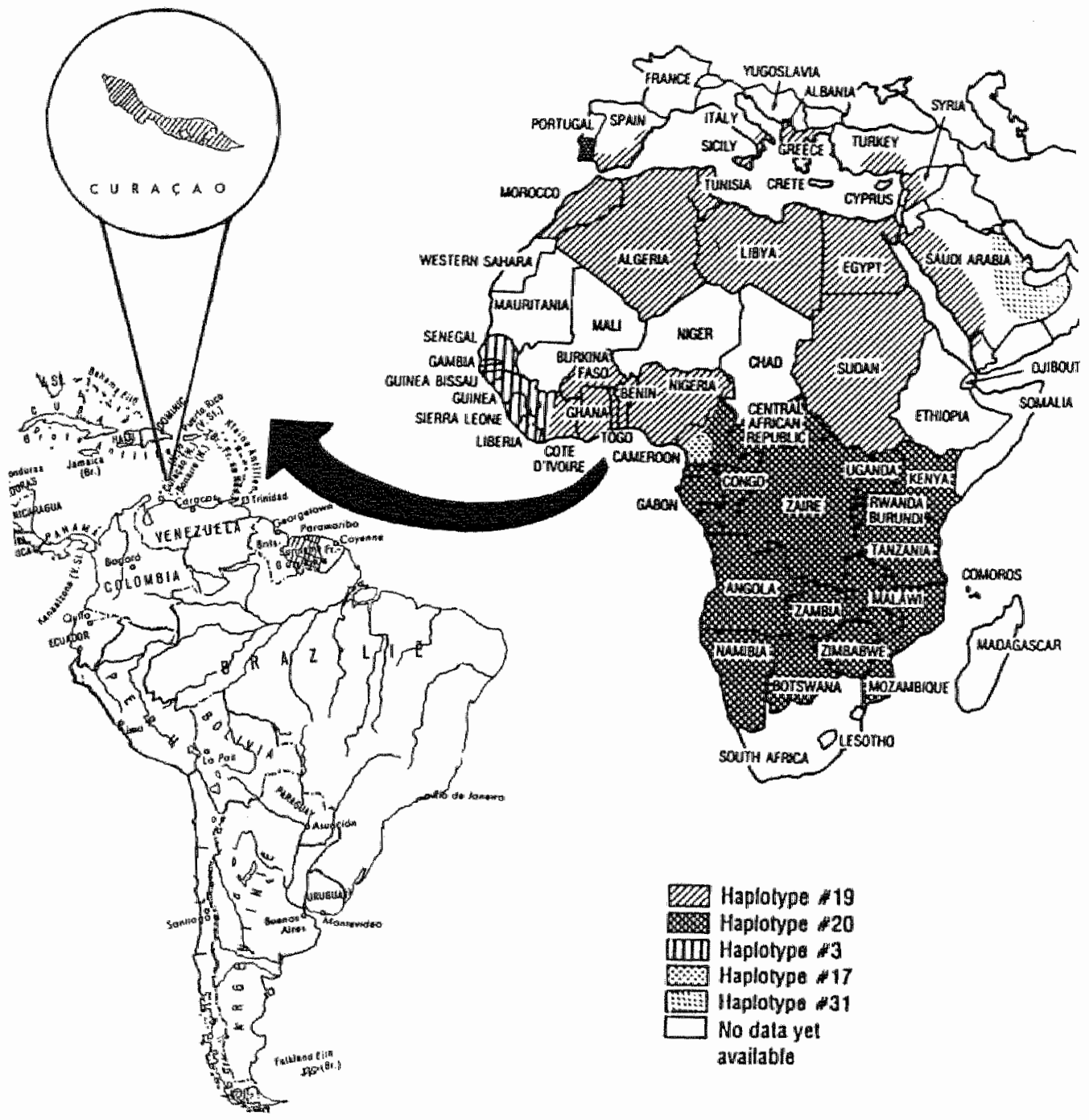

Figure II.1 Distribution of $\beta^{8}$ haplesypes in Atrica and the Mediterranean area, and the origin of the $19 / 19$ haphotype (Benin type) in Curaça (adapted from ref. 20). 


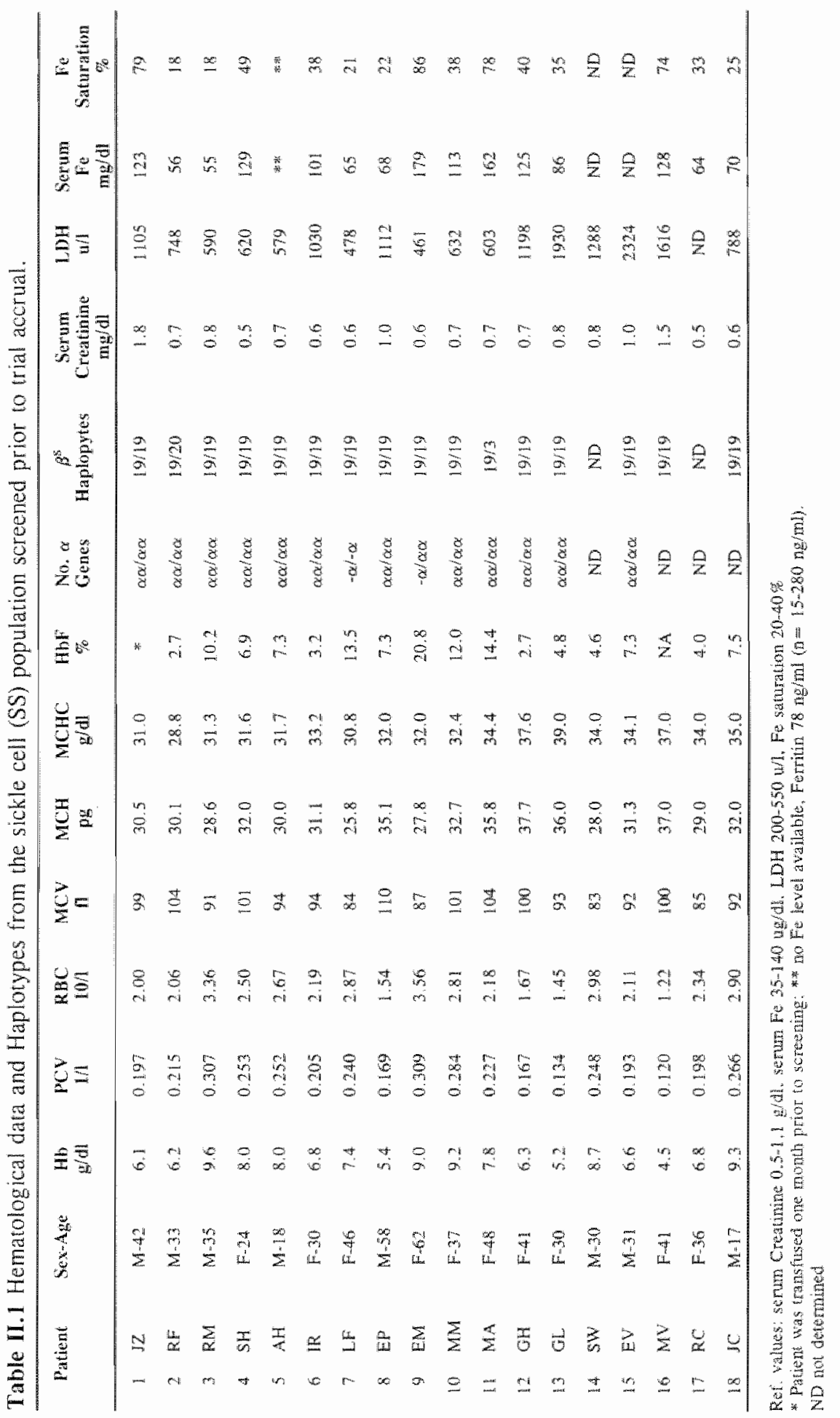




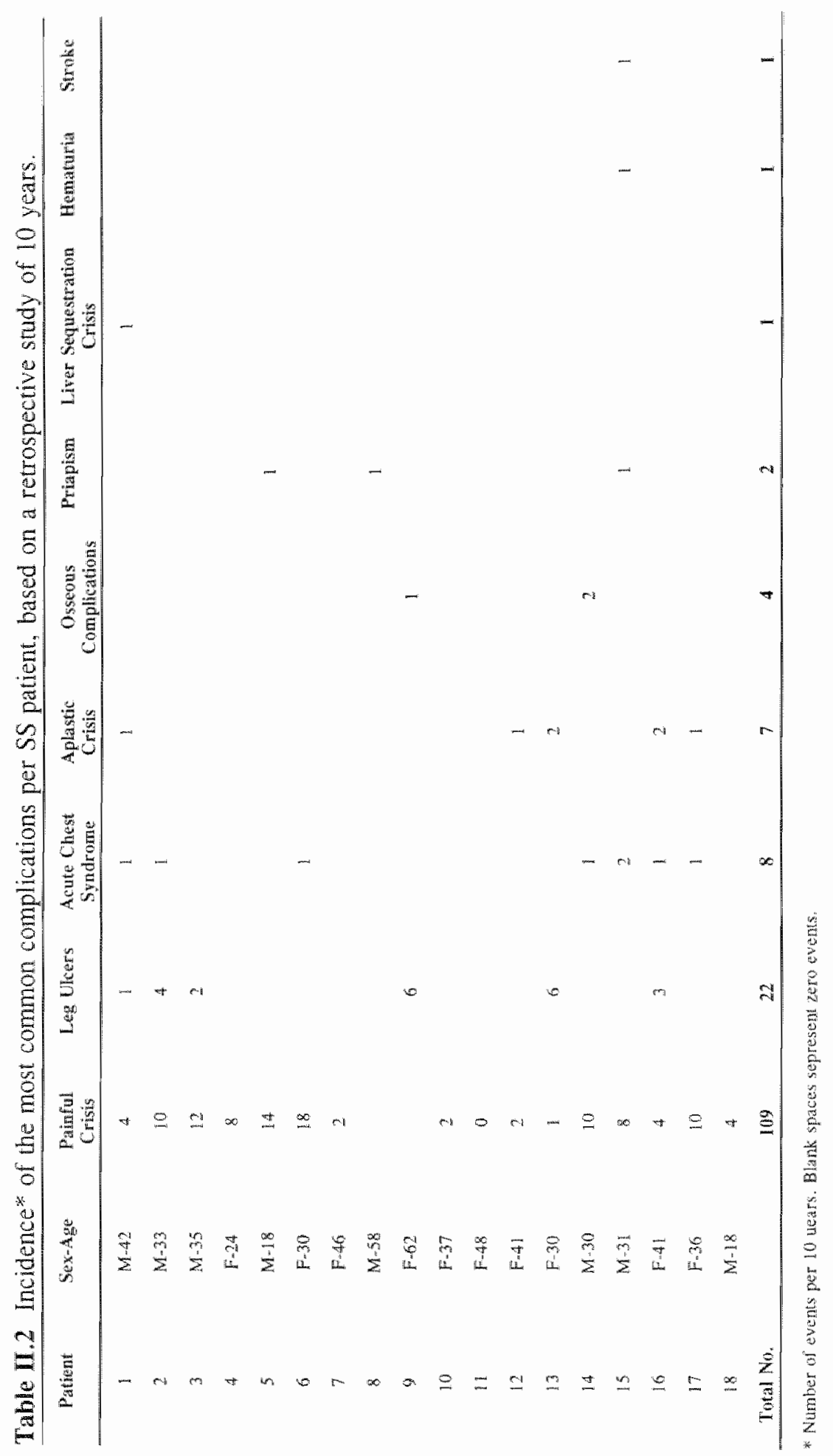


Table Ill.3 Summary of clinical complications resulting in permanent argan damage bused on a 10 year retrospective study of 18 SS patients varying in age from 19 to 64 years.

\begin{tabular}{|c|c|c|c|}
\hline Clinical complications & & Mechanism & No. of patients \\
\hline \multirow[t]{2}{*}{ Renat danage } & Hyposthenuriat & Obliteration of vasa recta & 18 \\
\hline & $\begin{array}{l}\text { Reduced Glonerular } \\
\text { hiltration nate (potients ower } \\
\text { the age of } 40 \text { yrs) }\end{array}$ & $\begin{array}{l}\text { Glonerular sclerosis. } \\
\text { ubuliar damage. infection } \\
\text { or renal infarcion }\end{array}$ & 3 \\
\hline $\begin{array}{l}\text { Splevis } \\
\text { inwolution }\end{array}$ & $\begin{array}{l}\text { Propensidy for betcerial } \\
\text { infections }\end{array}$ & $\begin{array}{l}\text { Chronic intrasinusoidal } \\
\text { sickling. infarchom and } \\
\text { fibrosis }\end{array}$ & $17^{*}$ \\
\hline laundiot & Elevated LDH and bilirubin & Chumic hemolysis & 18 \\
\hline Gallstones & $\begin{array}{l}\text { Asymptomatic or right } \\
\text { abdominal pain. smatl } \\
\text { bilirubin stones }\end{array}$ & $\begin{array}{l}\text { Enthanced excretion of } \\
\text { bilinubin }\end{array}$ & $11^{\circ *}$ \\
\hline Hemoctromatosis & $\begin{array}{l}\text { Liver or endocrine } \\
\text { dystuncrion, cardiate failune }\end{array}$ & $\begin{array}{l}\text { Excessive tissue iron } \\
\text { accumulation due to } \\
\text { franstustons or increased } \\
\text { iron intake }\end{array}$ & 4 \\
\hline Dearh & Multiple organ tailure & $\begin{array}{l}\text { Extensive renal/myocardial } \\
\text { dannage }\end{array}$ & 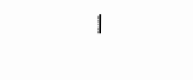 \\
\hline
\end{tabular}

- All patiens except for one assumed to have normal splenic function due to the presence of a-thalassemia;

" 8 cholecystectomies

\section{Painful crises}

Pain episodes, at times difficult to quantify taking into consideration the different factors that play a role in pain expression of patients, were recorded when patients had to be admitted to the hospital or when failure of non-opiate analgesics was apparent. The painful crisis was the most common clinical manifestation (Table II.2) occurring in particular during the second and third decade of life which is in agreement with international data.

\section{Acute chest syndrome (ACS)}

Eight episodes of ACS were counted in 7 individuals during the 10 years of retrospective survey (Table II.2). None of these patients died as a consequence of ACS. The survey done by van Agtmael et al in Curaçao ${ }^{25}$ revealed 81 episodes of acute chest syndrome in 53 patients over a 12 year period with a case fatality rate of $6 \%$, making the chest syndrome the most common cause of death in sickle cell patients in Curacao. 


\section{Hemochromalosis}

Based on clinical findings, serum iron and ferritio levels, 4 of the 18 SS patients screened were suspected to have some degree of hemochromatosis (Table II.1). Three patients (Patient J.Z., E.M. and M.V.) received many transfusions for low hemoglobin and related complants during the past years; one only received 14 transfusions but erroneously used oral iron supplements for a long time.

\section{Priapism}

Only two of the patients studied in this thesis had a serious episode of priapism (Table II.2). The patients were not questioned on the incidence of minor attacks.

\section{Bone complications}

One patient suffered some deformation of the medial femur condyl due to bone necrosis which eventually needed a correction by an orthopedic surgical procedure. Osteomyelitis is known to result from secondary infection of bone infarcts or avascular necrosis, as was the case for 2 of our SS patients. One of these patients even experienced two episodes of osteomyelitis.

\section{Leg ulceration}

During the 10 years of retrospective survey of the SS individuals. leg ulceration was common. The fact that legulcers are known to reoccur in the same individuals was confirmed by the finding of 22 events of leg ulceration in 6 SS patients (Table [1.2).

\section{Ocular abnormalities}

None of the patients were specifically screened for eye complications, but there were no complains related to their eyesight except for a limited and temporary visual perturbance in one patient experiencing a light stroke. Ocular abnormalities in sickle cell disease on Curaçao were described and reviewed by Van Meurs in $1990^{24}$. He confirmed the general finding that proliferative retinopathy is less common in $\mathrm{SS}$ than in SC individuals and reported an incidence of severe visual loss of $2 \%$ in SS patients.

\section{Renal conplications}

All patients showed hyposthenuria, defined as an specific density equal to or less than $1,010 \mathrm{~g} / \mathrm{ml}$ in an early morning urine portion. This was likely since the patients were all older than 15 years (the time at which concentrating capacity in SS patients is significantly impeded due to destruction of vasa recta in the kidneys).

\section{Pregnancy}

None of the pregnancies (total of 3) were complicated, only the newborns showed a 
low birth weight. No abortions were recorded.

\section{Mortality}

No data are readily available on life expectancy and mortality rate. As mentioned above the acute chest syndrome is the major cause of death among adult sickle cell patients in Curaçao. None of the 18 patients screened died prior to start of the studies in this thesis. One patient $(\mathrm{JZ})$, who did not meet the selection criteria for the studies, died a year later at age 43. Frequent painful crises combined with deterioration of renal function and cardiac failure resulting from high output. cardiomyopathy as well as possible hemochromatosis of myocardium (due to many transfusions) attributed to the cause of his death.

\section{L_ocal environmental influence}

In Curaçao painful crises are not likely to occur in relation to temperature changes since the climate is stable, dry and warm. However, it is the general impression that crises do happen more frequent during rainy seasons when flu episodes are common. Malaria, known to have a significant impact on the clinical course of sickle cell disease in the African continent, is not present in Curaçao and therefore does not constitute a threat to the local sickle cell population.

Due to the dry climate local agriculture is not pursued on a large scale. Therefore, adequate nutrition on the island depends partly on imported food products which can be relatively expensive. Even so adult sickle cell patients in Curaçao do not normally present with major nutritional deficiencies. In addition, because of chronic hemolysis, most patients are routinely prescribed a supplement of folic acid.

\section{Psychosocial aspects}

Although social class is known for it's influence on growth and physical development in a normal population this is not clearly the case for SS patients ${ }^{47}$. It is known that specific factors linked to social class may play a role in psychological development. However, in Curaçao most pediatric patients irrespective of their social class perform rather well in school (FAJ Muskiet, personal communication). With respect to the job, most adult SS patients without a permanent handicap, perform reasonably well as long as the work does not involve an especially high physical activity.

\section{Management}

Sickle cell patients in Curaçao receive medical care on an outpatient basis in several policlinics and most patients with acute illness are admitted to the Sint Elisabeth Hospital, a 700 bed facility. 
Although recently a multicenter study in the United States has shown hydroxyurea to be of some value in the prevention of painful crises $^{48}$, management of adult sickle cell patients is still mainly supportive. Medical care of the SS patient in Curaçao abides by international guidelines consisting of measures such as proper hygiene and counseling, early antibiotics in case of suspected infection and adequate analgesia for painful episodes. Local pediatricians do practice preventive medicine by routinely administering vaccines (Pneumovax and HIB) to their pediatric patients as well as by giving antibiotic profylaxis to the patients with frequent infections.

If deemed necessary patients are admitted to the hospital for rehydration, administration of oxygen and other more specific treatments depending on the type of complication. In the event of extreme anemia or aplastic crisis, transfusions are offered. When life threatening complications occur, exchange transfusions are commonly performed.

\section{Conclusions}

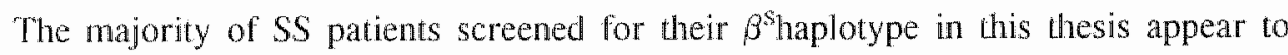
carry the Benin (19/19) type. This type is known in general for a rather severe clinical course. Today, despite the fact that llocal. medical care is up to international standards, several important data on the disease are still not being accurately registered; possibly, due to a lack of a sickle cell clinic where care is centralized. Most importantly, the financial costs involved in the current management of sickle cell disease are not known. They need to be disclosed in order to determine the burden of sickle cell disease on local health care and to be able to select ways to improve care of the sickle cell patient and to reduce expenses. Several means, such as routine screcning of newborns, antenatal diagnosis and new drug therapies, could be pursued to reduce the incidence as well as the financial costs and human sulfering that accompany sickle cell disease. Early diagnosis has been shown to produce better chances of survival for individuals inflicted with sickle cell disease ${ }^{49}$ and antenatal diagnosis by chorionic villus sampling, utilizing DNA amplification techniques and probes that identify the specific nucleotide change of sickle cell anemia during the early months of pregnancy, offers parents the possibility to avoid sickle cell disease within their offspring. However, these procedures should not be established without first determining their local feasibility and effectiveness through a careful cost/benefit analysis against a background of the general local health care. 


\section{References}

1. van der Sar A. Anemia con eritrocitos en forma hoz en la gestacion. Rev Pol Caracas 1943; vol2; 68.

2. van der Sar A. The occurence of carriers of abnomal haemoglobin $S$ and $\mathrm{C}$ on Curacao: Thesis, University of Groningen. The Netherlands, 1959.

3. Jonxis JHP. The frequency of hemoglobin $S$ and hemoglobin $C$ carriers in Curacao and Surinam. In "abnormal Hemoglobins "p 300-306, Blackwell $\mathrm{S}$ c i e w if i $\mathrm{c}$ Publications, Oxford. 1959

4. van Zanen GE. Expression of haemoglobin $\mathrm{S}$ gene on the island of Curaça. "Thesis, University of Groningen, The Netherlands, 1962.

5. Huisman THJ, van der Schaaf PC, van der Sar A. Investigations on the abnormal haemoglobin in sicklaemia and sickle cell trait. Doc de Med Geogr et Trop 1955; 7 : 285-289.

6. Huisman THJ, van der Schaaf PC, van der Sar A. Some characteristic properties of hemoglobin C. Blood 1955; 10: 1079-1091.

7. Statius van Eps LW, Schouren H, La Porte-Wijsman LW, Struyker Boudier AM. The influence of red blood cell transfusions on the hyposthenuria and renal hemodynamics of sickle cell anemia. Clin Chim Acta 1967; 17: 449-461.

8. Statius van Eps LW, Pinedo-Veels C, De Vries GH, and De Koning I. Nature of concentrating defect in sickle cell nephropathy. Microradio- angiographic studies. Lancet 1970 ; i: 450-45I.

9. Statius van Eps LW, Schouten H, Ter Haar Romeny-Wachter CH and La PorteWijsman $L W$. The relation between age and renal concentration capacity in sickle cell disease and hemoglobin C disease. Clin Chim Acta 1970; 27: 501-511.

10. Goossens JR, Statius van Eps LW, Schouten H. Incomplete renal tubular acidosis in sickle cell disease. Clin Chim Acta 1972; 41: 149-156.

11. de Jong PE, de Jong-van den Berg LTW. Statius van Eps LW. The tubular reabsorption of phosphate in sickle cell nephropathy. Clin Sci Mol Med 1978; 55: $429-434$.

12. de Jong PE, de Jong-van den Berg LTW, Donker AJM, Statius van Eps LW. The role of prostaglandins and renin in sickle cell nephropathy. A hypothesis. Neth d Med 1978; 21: 67-72.

13. de Jong PE, de Jongwan den Berg LTW, Sewrajsingly GH. Schouten H, Donker AJM, and Statius van Eps LW. The influence of indomethacine on renal hemodynamics in sickle cell anemia. Clin Sci 1980;59:245-250.

14. de Jong PE. Sickle cell nephropathy: New insights into its pathophysiology. Thesis, University of Groningen, The Netherlands, 1980.

15. de Jong PE, de Jong-wan den Berg LTW. Sewrajsingh GS, Schouten H, Donker A.M, Statius van Eps LW. Beta-2-microglobulin in sickle cell anemia. Evidence of increased tubular reabsorption. Nephron 1981; 29: 138-141.

16. de Jong PE. de Jong-wan den Berg LTW, Sewrajsingh GS, Schouten H, Donker AJM, Statius van Eps LW. The influence of indomethacin on renal concentrating and diluting capacity in sickle cell nephropathy. Clin Sci 1982; 63:53-58. 
17. de Jong PE, de Jong-van den Berg LTW, Sewrajsingh GS, Schouten H, Donker AJM, Statius van Eps LW. The influence of indomethacin on renal acidification in normal subjects and in patients with sickle cell anemia. Clin Nephrol 1983; 19:259 264.

18. de Jong PE, Saleh $A W$, de Zeeuw D, Donker $A J$, van der Hem GK, Prat JJ, Sewrajsingh GH. Statius van Eps LW. Urinary prostaglandins in sickle cell nephropathy: a defect in 9-keto-reductase activity. Clin. Nephrol 1.984; 22: 21-23.

19. de Jong PE, Statius van Eps LW. Sickle cell nephropathy: New insights into its pathophysiology. Kidney Int $1985 ; 27 ; 711-717$.

20. Schouten H, Statius van Eps LW, Delden GI van. Transketolase in sickle cell anemia. Clin Chim Acta 1971; 31: 487-488.

21. Statius van Eps LW, Schouten H, Sloof PA, Delden GI van. Sodium, potassium and calcum in erythrocytes in sickle cell anemia. Clin Chim Acta 1971; 33: 475 478.

22. Sewrajsingh GS, Schouten H, Statius van Eps LW. Intra-erythrocytic calcium in sickle cell anemia. Trop Geogr Med 1982; 34: 271-272.

23. Muskiet FD, Muskiet FA. Lipids, fatty acids and race elements in plasma and erythrocytes of pediatric patients with homozygous sickle cell disease. Clin Chim Acta 1984; $142: 1-10$.

24. van Meurs JC. Ocular findings in sickle cell disease on Curaça: Thesis, University of Nijmegen, The Netherlands, 1990

25. Van Agtmael MA, Cheng ID, Nossent HC. Acute chest syndrome in adult AfroCaribbean patients with sickle cell disease. Amn Intern Med 1994; 154 (5): 557-561.

26. Muskiet FAl., wan der Dijs FPL, Schermer JG, Muskiet FD, van der Slik W. Hemoglobinopathies and thalassemias in Curaçao. In: Muskiet FAJ ed. Tien j a a r samenwerking Landslaboratorium Curaçao en Academisch Ziekenhuis Groningen. Groningen, Schut \& Casparie, 1994: 41-49.

27. van der Dijs FPL, van den Berg GA. Schermer JG, Muskiet FD, Landman H, Muskiet FAJ. Screening cond blood for hemoglobinopathies and thalassemia by HPLC. Clin Chem 1992; 3879: 1864 1869.

28. Saleh AW, Pieters RC, Duits AJ. rhGm-CSF (Molgramostim): A potent inducer of sickle cell waso-occlusive crisis. Abstract for the 20th Annual Meeting. National Sickle Cell-Disease Program 1995, Philadelphia, USA.

29. Duits AJ, Pieters RC. Saleh AW, van Rosmalen $\mathbb{E}$, Katerberg H, Berend K, Rojer RA. Enhanced levels of soluble VCAM-I in sickle cell patients and their specific increment during vaso-occlusive crisis. Clin Immun Immunopathol 1996; 81: 96-98.

30. van der Dijs FP. van der Klis FR, Muskiet FD, Muskier FA. Serum calcium and vitamin D status of patients with sickle cell disease in Curaço. Ann Clin Biochem 1997: 34: 170-172.

31. Sehnog JI, Lard LR, Rojer RA, van der Dijs FP, Muskiet FA, Duits AJ. New concepts in assessing sickle cell disease severity. Am J Hematol 1998; 58: 61-66.

32. Duits AJ, de Vries C. Schnog JJ, Lard F, Muskiet F. Saleh AW. Elevated II-8 levels during sickle cell crisis (Eur I Hematol, in press). 
33. Muskiet FA, Muskier FD, Meiborg G. Schermer /O. Supplemenation of patients with homozygous sickle cell disease with zinc, alphawocopherol, vitamin $C$. soybean oil, and fish oil. Am J Chin Nutr 1991:54: 736-744.

34. Salet $A W$, van Goethem $A$, Jansen $R$, Velvis HIR, Gu L.H, Huisman THJ. Isobutyramide therapy in patients with sickle cell anema. Am Hematol 1995: 49: 244-246.

35. Pieters RC, Rojer RA, Saleh AW, Saleh AEC, Duits A. Molgramostim to treat SS sickle cell leg ulcers. The Lancet 1995; 345 : 528 (letter).

36. Saleh AW, H. Velvis, Hillen HFP, Gu L-H, Husman THJ Hydroxyurea therapy in sickle cell anemia patients in Curacao, The Netherlands Antilles. Acta Haematol 1997; 98: 125-129.

37. Saleh AW, Duits AJ, Gerbers A, de Vries C, Hillen HFP. Cytokines and soluble adhesion molecules in sickle cell anemia patients during hydroxyurea therapy. Acta Haematol 1998; 100: 26-31.

38. Fleming AF, Storey J, Molineaux L, Iroko EA, Atrai EDE. Abnormal haemoglobins in the Sudan savanna of Nigeria. 1. Prevallence of haemoglobins and relationships between sickle cell trait, malaria, and survival. Ann Trop Med Parasitol 1979:73: $161-172$.

39. Serjeant GR. Sickle cell disease 2nd edition, Oxford University Press, 1992.

40. Weatherall DJ, Gilles HM, Clegg JB, Blankson JA, Mustafa D, Boidoku FS, Chaudhury DS. Preliminary surveys for the prevalence of the thalassemia genes in some African populations. Ann Trop Med Parasitol 1971; 65: 253-265.

41. Ahern EJ, Swan AV, Ahern VN. The prevalence of iron deficient erythropoiesis and anemia in a rural Jamaican community. Br J Haematol 1972; 22: 273-280.

42. Leikin SL, Gallagher D, Kinney TR, Sloane D, Klug P, Rida W, and the Cooperalive study of Sickle Cell Disease. Mortality in children and adolescents with sickle cell disease. Pediatrics 1989; 84: 500-508.

43. Adekile AD. Sickle cell anaemia: Comparative clinical; and molecular studies of Nigerian and Kuwaiti patienis. Thesis. University of Limburg. Maastricht, "The Neherlands 1996.

44. Dimovski Al. Factors affecting the fetal hemoglobin levels in patients with sickle cell anemia and thalassemia. Thesis, University of Limburg, Maastricht. The Netherlands 1993, p 37.

45. Baysal E, Huisman THJ. Detection of common deletional $\alpha$-thalassemia-2 determinants by PCR. Am J Hematol 1994: 46: 208.

46. Codrington JF. Molecular characterization of haemoglobinopathies in the Surinam population. Thesis, University of Limburg, Maastricht, The Netherlands , 1992.

47. Platt OS, Rosenstock W, Espeland MA. Influence of sickle hemoglobinopathies on growth and development. N Engl I Med 1984; 311:7-12.

48. Charache S. Terrin ML, Moore RD "Dover GJ, Barton FB, Eckert SV, McMahon RP, Bonds DR and the Investigators of the Multicenter Study of Hydroxyurea in Sickle Cell Anemia. Effect of hydroxyurea on the frequency of painfull crises in sickle cell anemia. N Engl J Med 1995; 332: 1317-1322. 
49. Vichinsky EP. Comprehensive care in sickle cell disease: Its impact on morbidity and mortality. Semin Hematol. 1991; 28: 220.

50. Huisman THJ. The structure and function of normal and abnormal haemo-globins. In The Haemoglobinoparhies, edited by DJ Weatherall and DR Higgs, Balliere"s Clinical Haematology, Vol 6, page 1, WB Saunders Company, London, 1993. 


\section{Chapter III}

Pharmacological induction of fetal hemoglobin synthesis in sickle cell disease

AW Saleh, HFP Hillen

Neth J Med 1997;51:169-178 


\section{Summary}

In the present review the role and regulation of fetal hemoglobin ( $\mathrm{HbF}$ ) in sickle cell disease as well as the pharmacological modulation of $\mathrm{HbF}$ are discussed. Enhanced levels of HbF have an inhibitory effect on sickling and ameliorate the clinical course of sickle cell disease. This knowledge has incited a search for pharmacological agents capable of stimulating $\mathrm{HbF}$ production. Cytostatic drugs, in particular hydroxyurea, but also ather agents such as erythropoietin, butyrate and its analogues have been shown to induce $\mathrm{HbF}$ production. The mechanisms of action and the clinical effects of these agents are summarized. Only hydroxyurea has shown significant clinical effects in terms of reduction of paincrises, chest syndrome and transfusions in sickle cell patients. However, not all patients experience clinical amelioration and it appears difficult to predict which patient will gain from hydroxyurea therapy. Further studies need to expand the clinical experience with hydroxyurea, other $\mathrm{HbF}$ inducing agents and combinations of these drugs. Moreover, they will hopefully provide criteria to enable appropiate selection of those sickle cell patients that will benefit clinically from HbF stimulation, also taking into account the risks and costs of long-term pharmacological therapy. 


\section{Introduction}

Sickle cell anemia is a hereditary disorder characterized by an abnomality in the hemoglobin molecule. The molecular abnormality is caused by substitution of valine for glutamic acid, at the sixth residue of the $\beta$-chain. The sickle hemoglobin (HbS) when in deoxygenated state results in formation of molecular aggregates (polymerization). The process of polymerization distorts the red blood cell to a rigid sickle shape. The homozygous form, sickle cell (SS) disease, is characterized by chronic hemolysis that is stable and moderately debilitating, and episodic vasoocclusive crises that cause organ failure and account for most of the morbity and mortality associated with the disease. The heterozygous form (HbAS) or sickle cell trait is mostly asymptomatic due to the presence of more than 50 percent of normal HbA.

Deoxy $\mathrm{HbS}$ polymerization is also reduced in the presence of other Hb-types within the red cell. Fetal hemoglobin ( $\mathrm{HbF}$ ), normally lower than 2 percent but occurring at higher levels in sickle cell disease, is particularly beneficial in this respect because it forms a soluble complex with HbS, which results in a considerable prolongation of the time prior to polymerization and thereby may prevent red blood cells from sickling and improve their survival. This advantage has incited a search for products that modulate the HbF production in sickle cell disease.

The goal of this paper is to provide an overview on the regulation and role of fetal hemoglobin in sickle cell disease and to discuss mechanisms of action as well as clinical results of several pharmacological agents that stimulate HbF production.

\section{Regulation and role of fetal hemoglobin level}

Fetal hemoglobin is composed of two $\alpha$ and two $\gamma$ chains. The duplicated $\gamma$ genes are localized on the short arm of chromosome \#11. They differ slightly which results in two types of $\gamma$ chains namely the ${ }^{G} \gamma$ and ${ }^{A} \gamma$ chain. Hemoglobin synuhesis follows a developmental stage and tissue specificity. In the embryonic period $t$ chains are synthesized, but as soon as hematopoiesis shifts to the fetal liver in the 6th week, production of $\mathrm{HbF}$ is initiated. When the bone marrow becomes active in the second trimester and eventually becomes the most important hematopoietic site, production gradually switches from $\gamma$ chains to the adult $\beta$ (HbA) and $\delta$ (HbA2) chains. At birth babies with SS aswell as matched AA controls still carry HbF levels between 60 and $80 \%$ with the ratio between the two $\gamma$ chains being $70 \%{ }^{\circ} \gamma$ and $30 \%{ }^{A} \gamma$. In the first six months a second switch takes place involving reversal of the ${ }^{\mathrm{G}} \gamma$ and ${ }^{A} \gamma$ ratio from $70: 30$ to $40: 60$ (Figure III. 1 ). Simultaneously, the HbF level declines to an average of $1-2 \%$ at the age of 6 months. However, infants with sickle cell anemia show a much slower decrease of $\mathrm{HbF}^{12}$. 


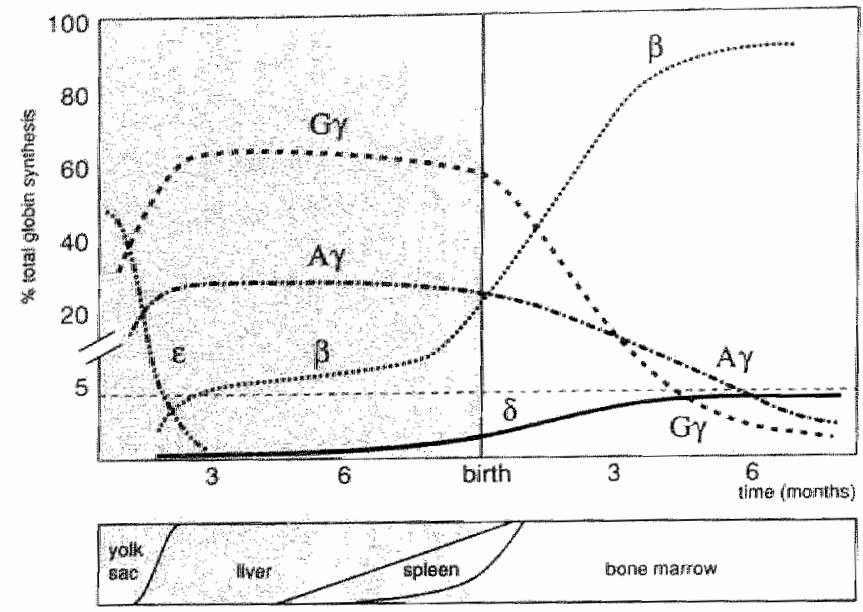

Figure III.1 Developmental switching of B-like globin genes Iadapted from ref. 56].

The proces of developmental hemoglobin switching appears to be controlled at the level of gene transcription. Regulation is exerted by promoter, enhancer and silencer elements (consisting of DNA sequences in close proximity to the structural globin genes) and by distant DNA sequences within the same chromosome interacting with certain regulatory nuclear proteins. The promoter ellements play an important role in the initiation of the transcription proces and modulate the efficiency of transcription. Enhancer and silencer elements influence the level of transcription. The distant DNA sequences are named the Locus Control Region (LCR). These sequences preferentially interact with $\gamma$ - and $\beta$-globin genes (Figure III.2).

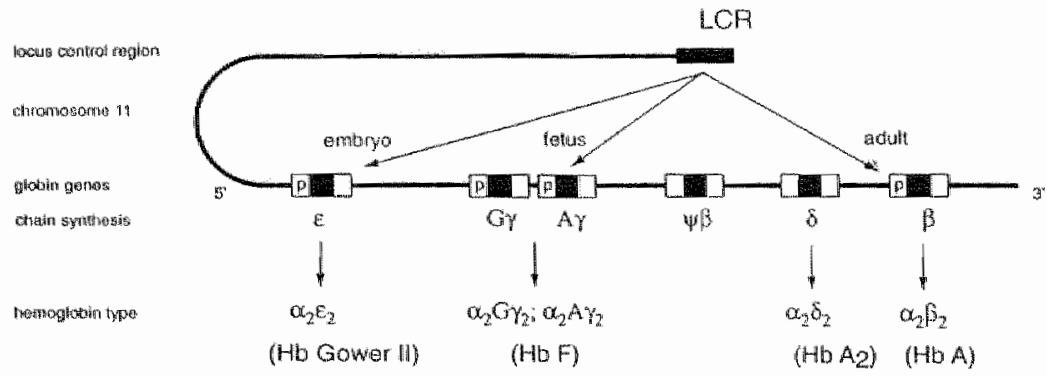

Figure III.2 Schematic presentation of the $\beta$-globin gene cluster of chromosome no. 11 showing organisation and sequential activation of the globin genes by interation with the locus control region (LCR). The letter $P$ denotes the pronotor regions. 
The LCR organizes the globin locus into an active chromatin domain and enhances globin gene transcription. The interaction of either the $\gamma$ promoter or the $\beta$ promoter with the LCR, and hence the developmental expression of $\gamma$-or $\beta$-globin genes, is a competitive process which is thought to depend on the presence of developmentally regulated (but still mostly unidentified) nuclear proteins ${ }^{2,3}$.

\section{Distribution of $\mathrm{HbF}$ among red blood cells}

The HbF in SS patients and normal adults is heterocellular and is mainly confined to erythrocytes named $F$ cells. The levels of $F$ - cells and HbF are considerably increased in sickle cell anemia. Due to preferential survival of F-cells the $\mathrm{HbF}$ level enhances even further. The relative proportion of $F$ cells in a given SS individual is remarkably constant and genetically determined ${ }^{1.2}$ but the HbF levels in peripheral blood show a considerable inter-individual variation, which may be attributed to differences in the production of F-cells, variation in the amount of $\mathrm{HbF}$ per F-cell and to the preferential survival of F-cells.

\section{Genetic factors influencing the $\mathrm{HbF}$ synthesis}

The broad distribution of the HbF levels in SS patients suggests that various factors control HbF production. Among these are the $\beta^{s}$ haplotype with mutations in promotor regions of the ${ }^{\mathrm{C}} \gamma$ and ${ }^{\wedge} \gamma$-globin genes, co-existent $\alpha$-thalassemia ( $\alpha$-thal), mutations which have been identified in the LCR region on chromosome 11, age and the X-linked F-cell production locus.

Five distinct sickle cell (SS) sub-types or $\beta^{s}$ haplotypes linked to the $\beta^{s}$-globin gene are recognised and they probably originate from the $\beta^{s}$ mutation occurring several times independently in individuals of different backgrounds. These haplotypes are named the Senegal, Cameroon, Benin,Bantu, and Saudi Arabia-lndia lype or number $3,17,19,20$ and 31 (Figure III.3). Studies by Gilman and Huisman as well as others ${ }^{5.8}$ have shown that a single nucleotide base mulailion $(\mathrm{C}->\mathrm{T})$ within the promotor region at position - 158,5 , to the ${ }^{\circ} \gamma$-globin gene, is associated with high ${ }^{G} \gamma$ and higher HbF levels. This mutation is characteristic of the Senegal (\#3) and Saudi Arabian(\#31) haplotype. It has been established that the presence of at least one chromosome with haplotype No 3. is sufficient to increase ${ }^{\mathrm{C}} \gamma$ and $\mathrm{HbF}$ levels and to improve the hematological profile.

In SS disease with co-existent $\alpha$-thalassemia the HbF levels are decreased. Dover et al. ${ }^{9}$ have demonstrated an inverse correlation between the number of $\alpha$-globin genes and non-F cells. They concluded that the lower HbF levels in $\alpha$-that reflect improved survival of non-F cells and are not due to intrinsic differences in $F$ cellor HbF-production. In $\alpha$-thal, the decrease in HbF levels is presumed to be the result of preferential formation of $\alpha \beta S$ dimers instead of $\alpha \gamma$ dimers. The improved survival of non-F cells in SS patients with co-existent $\alpha$-thalassemia can be 
atuributed to the lower mean corpuscular hemoglobin concentration.

Certain mutations in LCR region, characteristic for haplotype No. 3, are also associated with increased ${ }^{\circ} \gamma$ and $\mathrm{HbF}$ levels ${ }^{10}$.

When studying the effects of age and sex on HbF levels it is noted that newborns and children with sickle cell anemia up to the age of 5 years express high HbF levels $(20-40 \%)$ and thereafter $\mathrm{HbF}$ decreases gradually. After the age of 10 years, female sickle cell patients show consistently higher HbF in all age groups. Over the age of 40 years HbF levels remain stable in male SS patients while in female patienis an increase of $\mathrm{HbF}$ is observed'. Most recently, an X-linked locus which regulates $F$ - cell production (FCP locus) has been identified". The FCP locus is probably responsible for most if not all sex difference in $\mathrm{HbF}$ levels. Multiple regression analysis, including all abovementioned variables, has shown that the FCP locus is the most important predictor of the HbF level, accounting for $40 \%$ of the $\mathrm{HbF}$ variation. The $\beta$-globin haplotype, $\alpha$-globin gene number and age account for less than $10 \%$ of the variation ${ }^{11}$. The factors responsible for the other $50 \%$ of the variation in $\mathrm{HbF}$ levels still remain unknown.

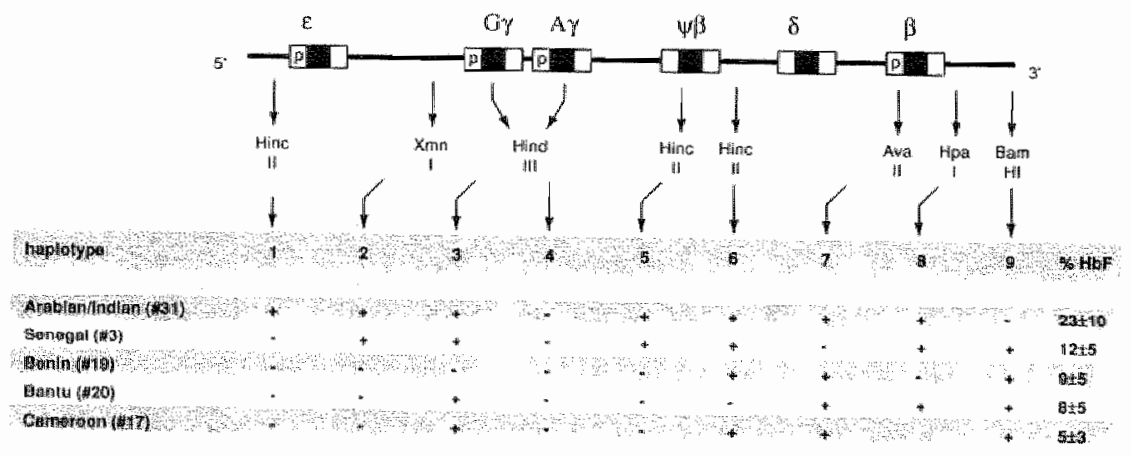

Figure III.3 DNA enzyme restriction sites identifying the five major SS haplotypes ffrom ret $1,57 !$.

\section{Clinical significance of $\mathrm{HbF}$ and the rationale of $\mathrm{HbF}$ induction in sickle cell disease}

The antisickling effect of $\mathrm{HbF}$ was first recognized by Watson in 1948 . He observed that red blood cells from infants with sickle cell anemia showed much less evidence of sickling as opposed to almost all cells of their sickle cell mothers. 
This observation was supported thereafter by several reports of compound $\beta^{\text {s. }}$ heterozygotes with higher $\mathrm{HbF}$ and hereditary persistence of $\mathrm{HbF}$ (S-HPFH), who showed much less signs of sickle cell disease. Perrine et al. ${ }^{i 2}$ reported that sickle cell patients from Saudi Arabia had relatively mild sickle cell disease due to $\mathrm{HbF}$ levels of $10-26 \%$. Later, a cohort study in Los Angeles revealed that patients with HbF levels above $10 \%$ were protected from major vaso-occlusive crises such as stroke or aseptic necrosis and patients with HbF levels in excess of $20 \%$ experienced much less painfull crises or pulmonary disorders ${ }^{13}$. Furthermore, a study by Platt et al. ${ }^{14}$ has demonstrated that life expectancy of sickle cell patients that carry $\mathrm{HbF}$ levels in excess of 8.6 percent approaches that of black male individuals without hemoglobinopathy and is practically equal to the life expectancy of males with HbSC disease.

The sparing effect of HbF on the sickling process has prompted a search for agents that can stimulate HbF production. Some cytostatic agents, in particular 5azacytidine and hydroxyurea, were found to have these properties. Because of its leukemogenic action, further studies of 5-Azacytidine were abandoned. Erythropoietin and butyrate analogues have also been shown to induce HbF production and recently it has been demonstrated that granulocyte-macrophage colony stimulating factor (GM-CSF), interleukin-3 (IL-3) and in particular stemcel factor ( $\mathrm{SCF}$ ) induce F-reticulocytosis in primates and human erythroid cell cultures.

\section{Mechanism of action and clinical effects of pharmacologic agents that stimulate HbF synthesis}

\section{Hydroxyurea}

This agent has mainly been used as a cytotoxic drug to control various myeloproliferative disorders. In fast dividing cells, hydroxyurea has effects on DNA by inhibiting the enzyme ribonucleotide reductase, blocking the conversion of ribonucleotides into deoxyribonucleotides. The mechanism of action of HbF induction, although not fully elucidated, is ascribed to selective proliferation of early erythroid progenitors which preserve the program for $\gamma$-chain synthesis but remain relatively inactive in the normal adult marrow, where erythropoiesis is dominated by mature progenitors carrying the $\beta$-chain synthesis pattern (Figure 111.4). In situations of acute bone marrow stress, such as recovery from the cytotoxic effects of hydroxyurea, the early erythroid progenitors are selectively recruited and proliferate maximally, resulting in an enthanced proportion of $\mathrm{HbF}$ in the new red cell population ${ }^{15}$. Furthermore, it has been shown that treatment with 5-azacytidine or hydroxyurea is associated with non-random hypomethylation of DNA around the $\gamma$ and $\beta$-globin gene complex and increase in $\gamma$ mRNA ${ }^{16,17}$. Hypomethylation of DNA can usually be demonstrated near aclive genes and hypermethylated DNA is found in the vicinity of inactive genes.

In addition to the action on HbF production, hydroxyurea also induces 
macrocytosis and improves red cell membrane deformability aswell as hydration status of erythroid cells ${ }^{18}$. Where the improvement of sickle cell hydration probably is an indirect result of the increase in $\mathrm{HbF}$, the macrocytosis and red cell deformability are most likely a unique property of the early erythroid progenitors. Furthermore, in vitro studies show that hydroxyurea affects morphology and modulates expression of vascular adhesion molecules in endothelial cells ${ }^{19}$ suggesting that a separate effect of hydroxyurea on endothelium-red blood cell interaction should be considered.

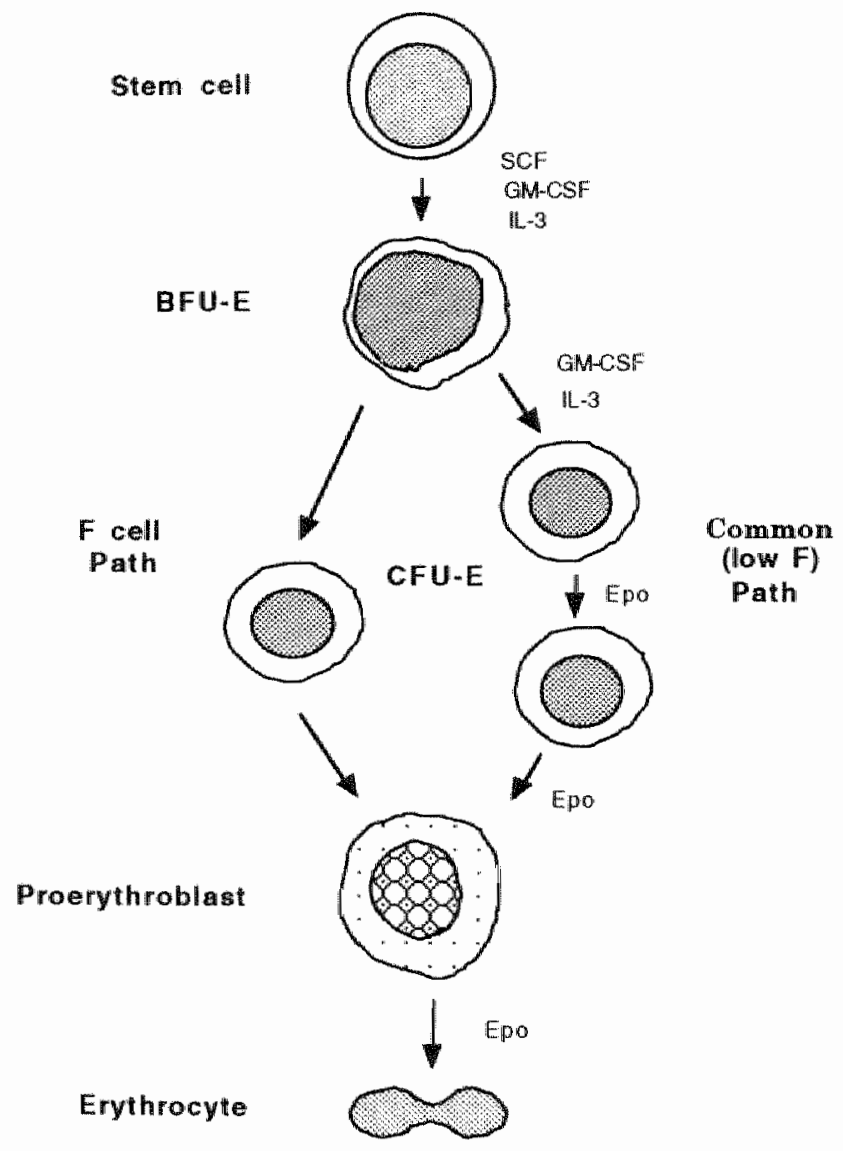

Figure 111.4 Diagram showing probiteration of erythroid progenitors. In situations of hematopoictic stress, proliteration of early erythroid progenitors, which carry the program tor rglobin synthesis is preferred, resulting in an enhanced proportion of F-cells and HWF. The action of eytokines. Erythropoietin (Epo), Gramulocyte-Macrophatge-Colony Stimulating Factor (GM-CSF) and Stemcell Fiactor (SCF), maximizes production of different stages of the erythrocyte
lineage. 
In several clinical studies ${ }^{20-25}$ most sickle cell patients treated with hydroxyurea characteristically showed decrease of hemolytic rate, increase of total hemoglobin, macrocytosis and varying increments in HbF (Figure III.5).

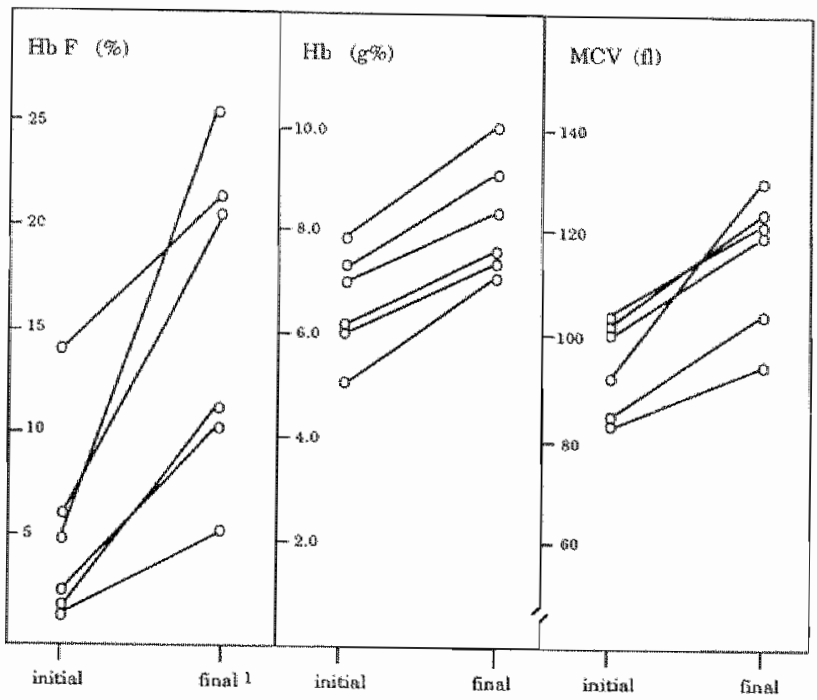

Figure 111.5 Levels of $\mathrm{HbF}$, total $\mathrm{Hb}$ and MCV of six SS patients treated with Hydroxyutea [adapted from ref. 25 .

The cause of this variability is unknown. No genetically determined differences in metabolism of hydroxyurea have been reported. In most patients HbF levels increase at low dosage of hydroxyurea whereas in some individuals a (minimal) response is only seen after long periods of therapy or at myelotoxic doses. The average dose of hydroxyurea used to stimulate $\mathrm{HbF}$ was $20 \mathrm{mg} / \mathrm{kg} /$ day. Intermittent or continuous dosing regimens have not resulted in significant differences in $\mathrm{HbF}$ response. In primates the HbF response also varied and a nucleotide difference in the $\gamma$-gene promoter was found, which accounted for the varying HbF response. No nucleotide sequence differences have been detected in $\gamma$-gene promoter region. of humans ${ }^{26}$. However, it is likely that other still undefined genetic factors together with the severity of hematopoietic stress may explain the variability in HbF response. Although clinical symptoms of some patients treated with hydroxyurea seemed to improve, no clear anwers were available on the frequency of painfull crises or other vaso-occlusive events during treatment. However, a recent multicenter trial of hydroxyurea in nearly 300 patients with sickle cell anemia in the United States ${ }^{27}$ showed that this drug can ameliorate the clinical course of some 
adult sickle cell patients. Painfull crises, chest syndrome and blood tranfusions were significantly decreased, while no differences were observed in stroke events, hepatic sequestration crises or mortality. Maximum tolerated doses of hydroxyurea were not required to reduce the incidence of painfull episodes. Some degree of myelo-suppression occurred in most patients but this did not result in serious complications. No deaths could be attributed to hydroxyurea. Still, it is noted that some patients that show significant increase of HbF do not appear to benefit from this therapy and may even fare worse $e^{25,28}$. One reason for this finding could be that the clinical improvement of a sickle cell individual is not solely dependent on $\mathrm{HbF}$ induction and reduction of HbS polymerization, but is also determined by the increase in total hemoglobin and packed cell volume. The latter changes could give rise to deleterious effects in the microcirculatory blood flow of especially prior damaged organs. Other explanations for the variable clinical response include the abovementioned effects of hydroxyurea on red cell volume, hydration status, the red cell membrane and a direct effect on endothelium.

So far, hydroxyurea treatment has not demonstrated any evidence of carcinogenesis in sickle cell patients. However, there are reports of longterm administration of hydroxyurea in myeloproliferative disorders that suggest that the drug may be involved in leukemogenesis ${ }^{29.30}$. Also, the effects of hydroxyurea on offspring, growth and development in children as well as longterm effects of hydroxyurea on progression of organ damage and mortality remain unresolved.

\section{Erythropoietin (Epo) and other hematopoietic growth factors}

A number of cytokines, in particular IL-3, GM-CSF and SCF have been demonstrated to stimulate $\mathrm{HbF}$ production in erythroid cell cultures and animals ${ }^{31}$. 35. SCF related superior increments in HbF compared to other cytokines but required the presence of Epo. Probably, SCF causes expansion of the pool of stem cells which in the presence of Epo differentiate and mature into F-cells. The mechanism of intracellular $\gamma$-gene activation still has to be unraveled, but erythroid transcription factors such as GATA-1 are thought to be involved as well as the socalled Homeobox genes and their proteins, that may recognize specific regulatory regions of $\gamma$-globin gene $e^{36}$.

Thus far none of these cytokines has been administered to SS patients with the purpose of HbF induction, except for Epo. High dose pulse therapy with Epo stimulates F-cell formation and $\mathrm{HbF}$ production in animals as well as in humans ${ }^{37}$ ${ }^{39}$. Erythropoietin is a growth factor that induces red cell formation by stimulating proliferation, differentiation, and maturation of erythroid progenitors and precursors. The exact mechanism by which erythropoietin induces HbF production at high doses is unclear but probably the resultant rapid regeneration of erythroid progenitors stimulates the formation of F-cells. While cooperative treatment of sickle cell patients with erythropoietin and hydroxyurea only produced moderate 
increase in HbF levels at besi ${ }^{39}$, the combination of Epo with hydroxyurea and iron supplementation produced a much more significant response ${ }^{40}$. It is doubted that this regimen, in view of the extremely high costs involved, would ever be of benefit to SS patients in general. Nevertheless, studies are currently underway to further expand the experience on cooperative Epo and hydroxyurea induction of $\mathrm{HbF}$ in SS patients.

\section{Butyrate and butyrate derivatives}

Butyric acid, a 4-carbon fatty acid, accurs naturally in the body and is formed by hydrolysis of ethylbutyrate. Studies show that this fatty acid affects morphology, growth rate and gene expression in mammalian cell cultures ${ }^{43}$. Infants, born to mothers with poorly controlled diabetes mellitus, have been noticed to have a delayed $\gamma \rightarrow \beta$ gene switch, which appears to be associated with high serum levels of $\alpha$-amino-n-butyric acid ${ }^{42,43}$. Subsequently, it has been shown that infusion of butyrate in the umbilical vein impedes the normal $\gamma \rightarrow \beta$ gene switch in sheep fetuses $^{\natural 4}$ and that butyrate stimulates $\gamma$-globin genes in cultured mammalian cells ${ }^{45}$. In addition to this action, butyrate displays other effects such as induction of cell differentiation, activation of cyclic AMP, effects on DNA methylation and growth inhibition $^{4 i, 46}$. These effects should be distinguished from the action on $\gamma$-globin synthesis. Gamma-globin synthesis is thought to be controlled at the level of transcription. Increases of $\gamma$-globin messenger RNA and globin protein production have been demonstrated in patients on butyrate, while at the same time a decrease in $\beta^{\mathrm{S}}$-globin messenger RNA was detected ${ }^{47}$. Gene assays in erythroid cell lines have already identified the region on the $\gamma$-globin gene which represents the butyrate-response promoter elements ${ }^{48}$. These findings imply that butyrate may act to increase HbF production in a complete different way than hydroxyurea. A pilot study by Perrine et al. ${ }^{47}$ reported remarkably rapid stimulation of $\gamma$-globin gene expression following intravenous arginine butyrate. F-reticulocyte levels increased within days and fetal hemoglobin synthesis increased significantly within three weeks. In another study with intravenous butyrate ${ }^{49}$ less impressive results were seen, but this difference could have resulted from the higher dosing regimen which is known to cause suppression of erythropoiesis". However, because butyrate is cleared by the liver and rapidly metabolized, its therapeutic use requires frequent or prolonged intravenous infusions. This practical disadvantage and the observation that butyrate metabolites could also induce HbF production ${ }^{5}$, resulted in identification of oral bioavailable butyrate derivatives capable of HbF induction. During the recent years there have been only a few reports on trials with butyrate analogues in sickle cell patients. Trials with the analogues sodium phenylbutyrate and isobutyramide show induction of $\gamma$ chains or HbF synthesis in patients $s^{52.54}$. However, the increments are moderate and rapid tolerance is observed. Also, there are concerns about neurological as well as gastrointestinal side effecis. Another 
structurally related compound, valproic acid, known for its use in epilepsy, has recently been shown to induce $\mathrm{HbF}$ but the data are still very limited ${ }^{5.5}$.

\section{Conclusions}

It is known that clinical disease expression varies greatly between SS patients. This, among other factors, is dependent on the levels of HbF. The presence of the $X$-linked FCP locus has been shown up until now, to be the most significant predictor of the HbF level. In general high $\mathrm{HbF}$ levels appear to ameliorate the severity of SS disease and because of this knowledge several pharmacological agents that induce HbF production have been studied and are still being studied. Hydroxyurea stimulates HbF production but the response is highly variable. In clinical studies, hydroxyurea imparts a reduction in painfull crises, chestsyndrome and transfusions to some patients, but others do not experience improvement and may even fare worse. The addition of iron supplements and high dose pulse therapy with Epo to hydroxyurea increases $\mathrm{HbF}$ levels even further but there are very few data on the clinical effects. Moreover, the administration of hydroxyurea still carries an unknown risk of carcinogenicity and teratogenicity while the longterm effects of hydroxyurea on mortality remain unresolved. These findings indicate that strict laboratory and clinical terms have to be established to enable careful selection of those SS patients that will truly benefit from treatment with hydroxyurea. Butyrate analogues stimulate $\mathrm{HbF}$ production by a different mechanism compared to hydroxyurea. They have the theoretical advantage of not being potentially carcinogenic drugs. However, they will probably not replace hydroxyurea but instead may be of additive or synergistic value to treatment with hydroxyurea or other drugs.

Several ongoing studies as well as future triats will continue to expand on the clinical experience with $\mathrm{HbF}$ inducing agents in SS patients. Although progress is also made in other treatment modalities such as bone marrow transplantation and gene therapy, pharmacological ways of stimulating $\gamma$ genes will continue to improve and remain a valuable option to the treatment of sickle cell disease in the nexi decennium. 


\section{References}

1. Adekile AD, Huisman THJ. HbF in sickle cell anemia. Experienta 1993; 49: 1627.

2. Embury SH, Hebbel RP. Mohandas N, Steinberg MH. Sickle Cell Disease, basic principles and clinical practice 1994, by Raven Press Lid, New York.

3. Stamatoyannopoulos G. Human hemoglobin switching. Science 1991;252: 383 .

4. Kan YW, Dozy M. Evolution of the hemoglobin $S$ and $C$ genes in world population. Science 1980; 208: 388.

5. Dover GJ, Boyer $\mathrm{SH}$, Charache $\mathrm{S}$, Heintzelman $\mathrm{K}$. Individual variation in the production and survival of F-cells in sickle cell disease. N Engl I Med 1978; 299: $1428-1.435$.

6. Gilman JG, Huisman THJ. DNA sequence variation associated with elevated fetal ${ }^{6} \gamma$-globin production. Blood 1985; 66: 783-787.

7. Labie D, Dunda-Belkhodja O, Rouabhi F, Pagnier J, Ragusa A, Nagel RL. The 158 site 5 ' to the ${ }^{\mathrm{C}} \gamma$ gene and ${ }^{\circ} \gamma$ expression. Blood 1985; 66: 1463-1465.

8. Miller BA, Olivieri $N$, Salameh $M$, et al. Molecular analysis of the highHemoglobin F phenotype in Saudi Arabian sickle cell anemia. N Engl I Med 1987; 316: $244-250$.

9. Dover GJ, Chang VT, Boyer SH, Serjean GR, Antonarakis SE, Higgs DR. The cellular basis for different fetal hemoglobin levels among sickle cell individuals with two, three and four ox-globin genes. Blood 1987; 69: 341-344.

10. Oner C, Dimovski AJ, Altay C, Gurgey A, Gu YC, Huisman THJ, Lanclos KD. Sequence variations in the $5^{\prime}$ hypersensitive site- 2 of the locus control region of $\beta^{\mathrm{s}}$ chromosomes are associated with different levels of fetal globin in $\mathrm{HbS}$ homozygotes. Blood 1992; 79: 813-819.

11. Chang YC, Smitl KD, Moore RD, Serjeant GR, Dover GJ. An analysis of fetal hemoglobin variation in sickle cell disease: The relative contributions of the $X$ linked factor, $\beta$-globin haplotypes, $\alpha$-globin gene number, gender and age. Blood 1995: 85: 11111-1117.

12. Perrine RP. Pembrey ME, John P. Perrine $S$, Shoup F. Natural history of sickle cell anemia in Saudi Arabs: A study of 270 subjects. Ann Intern Med 1978;88:1-6.

13. Powars DR, Weiss JN, Chan LS. Schroeder WA. Is there a threshold level of fetal hemoglobin that ameliorates morbidity in sickle cell anemia ? Blood 1984; 63: 921 926.

14. Platt OS, Brambilla DJ, Rosse WF, Milner PF, Castro O, Steinberg MH, Klug PP. Mortality in sickle cell disease: Life expectancy and risk lactors for early deatl. N Engl I Med 1994; 330: 1639-1644.

15. Stamatoyannopoulos $\mathrm{G}$, Veith R, Calanello R, Papayannopoulou T. HbF production in stressed erythropoiesis: observations and kinetic models. Annals of the New York Academy of Sciences 1985; 445: $188-197$. 
16. Charache S, Dover GJ, Smith K, Talbot CC Jr, Moyer M. Boyer S. Treatment of sickle cell anemia with 5 -azacylidine results in increased fetal hemoglobin production and is associated with nonrandom hypomethylation of DNA around the $\gamma-\not{\alpha}-\beta$-globin gene complex. Proc Natl Acad Sci USA 1983; 80: 4842-4846.

17. Constantoulakis $P$, Josephson $B$, Mangahas $L$, Papayannopoulou Th, Enver $T$, Constantini F, Stamatoyannopoulos G. Locus control region- $\gamma \gamma$ transgenic mice: A new model for studying the induction of fetal hemoglobin in the adult. Blood 1991 ; 77: 1326-1333.

18. Ballas SK, Dover GJ, Charache S. Effect of hydroxyurea on the rheological properties of sickie erythrocyles in vivo. Am J Hematol 1989; 32: 104-111.

19. Adragna NC. Fonseca P, Lauf PK. Hydroxyurea affects cell morphology, cation transport, and red blood cell adhesion in cultured vascular endothelial cells. Blood 1994; 83: 553- 560 .

20. Charache S, Dover G, Moyer M, Moore J. Hydroxyurea-induced augmentation of fetal hemoglobin production in patients with sickle cell anemia. Blood 1987; 69: $109-116$.

21. Sumoza $A$, Bissotti RS. Treatment of sickle cell anemia with hydroxyurea: results in twenty-six patients. Blood 1986; 68:67a (Abstract).

22. Platt $O$, Orkin $S$, Dover $G$, Beardsley $P$, Miller B. Hydroxyurea enhances fetal hemoglobin production in sickle cell anemia. J Clin Invest 1987; 74:652-656.

23. Rodgers GP, Dover G», Noguchi CT, Schechter AN, Nienhuis AW. Hematologic responses of patients with sickle cell disease to treatment with hydroxyurea. $\mathrm{N}$ Engl J Med 1990; 322: 1037-1045.

24. Veith R, Galaneilo R, Papayannopoulou T, Stamatoyannopoulos G. Stimulation of F-cell production in patients with sickle cell anemia treated with cytarabine or hydroxyurea. N Engl J Med 1985; 313: 1571-1575.

25. Saleh AW, Velvis HIR, L-H Gu, Hillen HFP, Huisman THJ. Hydroxyurea therapy in sickle cell anemia patients in Curaçao, The Netherlands Antilles. Acta Haematol 1997: 98: 125-129.

26. Ecomomou EP. Antonarakis SE, Kazazian HJ, Serjeant GR, Dover GI: Variations in the henoglobin $\mathrm{F}$ production among normal and sickle cell adults is not related to nucleotide substitutions in the gamma promoter regions. Blood 1991; 77: 174-177.

27. Charache S, Terrin ML, Moore RD, Dover GJ, Barton FB, Eckert SV, McMahon RP. Bonds DR and the Investigators of the Multicenter Study of Hydroxyurea in Sickle Cell Anemia. Effect of hydroxyurea on the frequency of painfull crises in sickle cell anemia. N Engl J Med 1995; 332: 1317-1322.

28. Vichinsky EP, Lubin BH. A cautionary note regarding hydroxyurea in sickle cell disease. Blood 1994: 83: 1124-1128.

29. Nand S, Messmore H, Gross Fischer S, Lourdes Bird M, Schulz W, Fisher RI. Leukemogenic transformation in polycythemia vera: Analysis of risk factors. Am I Hematol 1990; 34: 32-36.

30. Weinfeld A. Swolin B. Westin J. Acute leukemia after hydroxyurea therapy in polycythemia vera and allied disorders: Prospective study of efficacy and leukaemogenicity with therapeutic implications. Eur J Haematol 1994; 52: 134-139 
31. Giabbianelli $M$, Pelosi $E$, Bassano E, et al. Granulocytemacroplyge colonystimulating factor reactivates fetal hemoglobin synthesis in erythroblast clones from normal adults. Blood 1989; 74: 2657- 2667.

32. Umemura $T$, al-Khati $A$, Donahue RE, Papayamopoulou $T$. Stamamoyamopoulos G. Effects of interleukin-3 and erythropoietin on in vivo erythropoiesis and F-cel formation in primates. Blood 1989; 74: 1571-1576.

33. Migliaccio AR, Migliaccio G, Brice M, Constantoulakis P. Stamatoyanopoulos G, Papayannopoulou $\mathrm{T}$. Influence of recombinant hematopoietins and of fetal bovine serum on the globin synthetic pattern of human BFU-E. Blood 1990; 76: 11501157.

34. Miller BA, Perrine SP, Bernstein A, Lyman SD, Williams DE, Bell LL, Olivieri NF. Influence of Steel Factor on hemoglobin synthesis in sickle cell disease. Blood $1992 ; 79: 1861-1868$.

35. Lavelle D, DeSimone J, Heller P. Fetal Hemoglobin Reactivation in Baboon and Man: A Short Perspective. Am J Hematol 1993; 42: 91-95.

36. El-Hazmi MAF, Al-Momen A, Kandaswamy S, Huraib S, Harakati M. Al-Mohareb F, Warsy AS. On the use of Hydroxyurea/Erythropoietin combination therapy for sickle cell disease. Acta Haematol 1995; 94: 128-134

37. McDonagh KT, Dover GJ, Donahue R, Nathan DG, Nienhuis AW. Manipulation of HbF production with hematopoietic growth factors. Prog Clin Biol Res 1989; 316 B: $307-315$

38. Al-Khatti A, Veith RW, Papayannopoulou T, Fritsch EF, Goldwasser E, Stamatoyannopoulos G. Stimulation of fetal hemoglobin synthesis by erythropoietin in baboons. N Engl J Med 1987; 317: 415-420.

39. Goldberg MA, Brugnara C, Dover G.l, Schapira I, Charache $S$, Bunn HF. Treatment of sickle cell anemia with hydroxyurea and erythropoietin. N Engl J Med $1990 ; 323: 366-372$.

40. Rodgers GP, Dover GI, Uyesaka $\mathbb{N}$, Noguchi C, Schechter AN, Nienhuis AW. Augmentation by erythropoietin of the retal hemoglobin response to hydroxyurea in sickle cell disease. N Engl J Med 1993; 328: 73-80.

41. Prasad K. Butyric acid: a small fatly acid with diverse biological funcrions. Life Sci $1980 ; 27: 1351-1358$.

42. Perrine SP, Greene MF, Faller DV. Delay in the fetal globin switch in infants of diabetic mothers. N Engl I Med 1985; 312:334-338.

43. Bard $\mathrm{H}$, Prosmanne I: The relative mates of fetal and adult hemoglobin synthesis in cord blood of infants of insulin-dependent diabetic mothers. Pediatrics 1985; 75: $1143-1147$.

44. Perrine SP. Rudolph A, Faller DV, Roman C, Cohen RA, Chen S-J, Kan YW. Butyrate infusions in the ovine fetus delay the biologic clock for globingene switching. Proc Natl Acad Sci USA 1988: 85:8540-8542.

45. Perrine SP, Miller BA. Faller DV, et al. Sodium butyrate enhances fetal globin gene expression in erythroid progenitors of patients with HbSS and $\beta$-thalassemia. Blood 1989; $74: 454-459$. 
46. Constantoulakis $P$, Knitter G. Stamatoyannopoulos G. On the induction of fetal hemoglobin by butyrates: in vivo and in vitro studies with sodium butyrate and comparison of combination treatments with 5-AzaC and AraC. Blood 1989; 74: 1963-1971.

47. Perrine SP, Ginder GD, Faller DV, et al. A short-term trial of butyrate to stimulate fetal-globin -gene expression in the beta-globin disorders. N Engl J Med 1993; 328: $81-86$.

48. Perrine SP, Dover GH, Daftari P, Walsh CT, Jin YX, Mays A, Faller DV. Isobutyramide, an orally bioavaible buyrate analogue, stimulates fetal globin gene expression in vitro and in vivo. Br. J Haematol 1994: 88: 555-561.

49. Sher GD, Entsush B, Ginder G, et al. Intravenous infusions of arginine butyrate increases $\gamma$-globin mRNA expression and F-reticulocytes in patients with homozygous $\beta$-thalassemia and sickle cell disease. Blood 1993; 82: 312a (abstract).

50. Faller DV, Perrine SP. Butyrate treatment of sickle cell disease and $\beta$-thalassemia. Current Opinion in Hematology 1995;2: 109-117.

51. Stamatoyannopoulos $G$, Nakamoto B, Josephson $B$, et al. Acetate, a product of butyrate catabolism stimulates $\gamma$-globin expression in adult cells in vivo and in culture. Blood 1993; 82 (suppl 1): 313a (abstract).

52. Costin $D$, Dover $G$, Olivieri $N$, et al. Clinical use of the butyrate derivative Isobutyramide in the $\beta$-globin disorders. Blood 1993; 82 (suppl 1): 357a (abstract).

53. Dover GJ, Brusilow $S$, Charache $S$. Induction of fetal hemoglobin production in subjects with sickle cell anemia by oral sodium phenylburyrate. Blood $1994 ; 84$ : 339-343.

54. Saleh $A W$, van Goethem $A$, Jansen $R$, Velvis HJR, Gu L-H, Huisman THJ Isobutyramide therapy in patients with sickle cell anemia. Am I Hematol 1995; 49: 244-246.

55. Wood A, Davies SC. Induction of haemoglobin F in sickle cell anemia by sodiumvalproate. Blood 1995; 86(supp/ 1): 141 a (abstract).

56. Huisman THJ. The structure and function of normal and abnormal haemoglobins. The Haemoglobinopachies, edited by D.J. Weatherall and D.R. Higgs, Bailliere's Clinical Haematology, vol. 6, page I, W.B. Saunders Company, London, 1993.

57. Wood WG. Increased HHF in aduit life. In: Higgs DR, Weatherall DJ, editors. The Haemoglobinopathies. Bailliere"s Clinical Haematology. London: Bailliere Tindal, 1993: 6: 177-213. 


\section{Chapter IV}

\section{Aims of the study and thesis outline}

AW Saleh 


\section{Aims of the study and thesis outline}

Many drugs have been tried and advocated for ameliorating the clinical severity of sickle cell disease during the past three decades. None of these has been so extensively investigated as the group of agents that confer a reduction in the polymerization rate of sickle cells by induction of $\mathrm{HbF}$ production. This latter group, consisting of hydroxyurea, the short chain fatty acids (butyrates) and erythropoietin, cause induction of HbF in erythroid progenitors by different mechanisms which are discussed in chapter II. The net effect of these agents on $\mathrm{HbF}$ production is very variable. The cause of this variability is not clear and requires further analysis to enable appropriate patient selection and avoid unnecessary treatment. Certain sickle cell patients may reveal a relatively benign course of disease due to several factors, such as genetic, vascular or environmental determinants, and may not benefit from treatment that involves $\mathrm{HbF}$ induction. Moreover, treatment would probably have to be administered on a long-term basis, which theoretically poses a risk of carcinogenicity and teratogenicity for agents such as hydroxyurea. In this respect further studies on the effects on $\mathrm{HbF}$ production by oral butyrate derivatives could establish worthwhile alternatives to hydroxyurea.

Not only does the inter-individual HbF production differ significantly, but the clinical effects of hydroxyurea treatment in sickle cell patients cannot always be correlated to the changes in $\mathrm{HbF}$. This suggests that, in addition to the HbF induction and changes in hematologic profile, other effects of hydroxyurea may play a role in the final therapeutic outcome. As stated in chapter I of this thesis, red blood cells, leucocytes, platelets and endothelium are intricately involved in the mechanism of sickle cell vaso-occlusion. The adhesion process is also heavily influenced by several plasma factors such as certain cytokines and procoagulant factors. Actions of hydroxyurea on some of the determinants of cellular adhesion, vascular endothelium and cytokine production may play an important role. In fact. apart from reducing the number of leucocytes, hydroxyurea has been shown to cause specific changes in endothelial cells in vitro and to alter red blood cell properties.

Also, cytokines are vital to hematopoiesis, and even more so to stress hematopoiesis. In sickle cell anemia the interactions between erythropoietin (Epo), stem cell factor (SCF), interleukin-3 (IL-3), granulocyte-macrophage stimulating factor (GM-CSF) and the erythroid pool are of critical importance. However, their behaviour during hydroxyurea treatment is not known. 
The specific aims of the studies described in this thesis are:

* To study the effects on HbF production in sickle cell (SS) patients of the oral butyrate analog, isobutyramide, which has the theoretical advantage of lacking the carcinogenic potential like cytostatic drugs such as hydroxyurea. (Chapter VI)

* To examine whether hydroxyurea causes increases of HbF production in homozygous sickle cell patients standardized for the same $\beta^{s}$-haplotype. (Chapter VII)

* To study if hydroxyurea treatment in SS patients results in clinicall improvement, counted as reduction in painful crises or other specific vasoocclusive crises. (Chapter VII)

* To determine if hydroxyurea therapy in SS patients influences the levels of IL-3, GM-CSF, Epo, SCF, as well as various soluble adhesion molecules and to study wether $\mathrm{HbF}$ levels and $\mathrm{HbF}$ induction are in any form related to plasma cytokine activity. (Chapter VIII)

* To study the levels of endothelial (sVCAM-1, fibronectin, IL-8), neutrophil (myeloperoxidase, sIL-6 receptor $\alpha$, SL-selectin) and platelet (VWF) derived factors in SS patients during hydroxyurea therapy. (Chapter IX) 


\title{
Chapter V
}

\section{Materials and Methods}

\author{
AW Saleh
}


This chapter provides general information on the patients who cooperated and the techniques that were used in these studies.

\section{Patients}

Of the 18 SS patients that were screened prior to the start of the studies in this thesis, 11 patients cooperated with one or more studies. The inclusion criteria for participation were a Benin haplotype with four intact $\alpha$-globin genes, normal serum creatinine level, normal liver function and no pregnancy. Two patients were excluded because of an abnormal serum creatinine. Of the remaining 14 patients three did not wish to participate. Table V.1 shows specifically which patients participated in each of the studies. Before participation informed consent was obtained from each patient. Charts and hospital records were reviewed for their medical history and laboratory data. These are summarized in chapter II. The clinical features of each patient individually are mentioned in the studies described in this thesis. During the study patients visited an outpatient clinic, once every month, for physical exam. During these visits clinical symptoms (especially painful crises) and complications were registered. In order to obtain the most information, patients were encouraged to record their symptoms in a diary. In the event of a severe painful crisis or serious complication, patients were admitted to the St. Elisabeth Hospital for further treatment. Painful crises were defined as severe pains in the bones of the extremities, back, abdomen or chest which were not relieved by non-narcotic analgesics (acetaminophen).

Of the 18 patients that were screened, 16 had their haplotype determined at the laboratory of the Comprehensive Sickle Cell Center in Augusta, GA, USA (Director: Prof THJ Huisman).

Table V.1. Allocation of patients to each of the studies

\begin{tabular}{|c|c|}
\hline Study & Patients (Initial) \\
\hline $\begin{array}{l}\text { Isoburyramide therapy in parients sickle cell anemia (chapter } \\
\text { VI) }\end{array}$ & $\begin{array}{l}A(M A), B(R M), C(E P) \\
D(I R)\end{array}$ \\
\hline $\begin{array}{l}\text { Hydroxyurea therapy in sickle anemia patients in Curacalo, } \\
\text { Netherlands Antilles (chapter VII) }\end{array}$ & $\begin{array}{l}A(E P), B(I R), C(R M), \\
D(M M), E(M A), F(A H) \\
G(C H), H(R F), I(G L)\end{array}$ \\
\hline $\begin{array}{l}\text { Cytokines and soluble adhesion molecules in sickle cell } \\
\text { anemia patients during hydroxyureat therapy (chapter VIII) }\end{array}$ & $\begin{array}{l}A(E P), B(N), C(M M) \\
D(M A), E(G H), F(R F) \\
G G L)\end{array}$ \\
\hline $\begin{array}{l}\text { Levels of endothelial neutrophit. and platelet-specific } \\
\text { factors in sickle cell anemia patients during bydroxyurea } \\
\text { therapy (chapter IX) }\end{array}$ & $\begin{array}{l}A(E P), B(O R), C(R M) \\
D(M A), E(G H), F(R F) \\
G(E N), H(N C)\end{array}$ \\
\hline
\end{tabular}




\section{Blood collection and shipment}

About $10-20 \mathrm{ml}$ of blood for haematological analysis was obtained by venepuncture into vacutainers with EDTA as anticoagulant. Also, 5-10 ml of blood was obtained for chemical analysis. Samples for haplotype and $\mathrm{HbF}$ determination at the laboratory in Augusta were shipped on ice by courier service the same day and always arrived at destination within 2 days.

\section{Haematological data}

$C B C$ 's and red cell indices were determined with a fully automated Onyx Coulter Counter.

\section{Hb Analyses}

RBC's were washed with isotonic saline and haemolysed with 1.5 volumes of water and 0.4 times the volume of $\mathrm{CCl} 4$ for 15 minutes at room temperature. Stroma was removed by centrifugation at 20.000 at $4^{\circ} \mathrm{C}$ for 20 minutes. These haemolysates were used for electrophoretic and chromatographic studies.

\section{Hb Electrophoresis}

Diagnosis of SS disease was made by $\mathrm{Hb}$ electrophoresis. The principle of this technique is based on a charge change in the hemoglobin molecule that occurs with certain amino acid substitutions. The replacement by valine of glutamic acid in $\mathrm{HbS}$ results in a more net positively charged $\mathrm{Hb}$ relative to $\mathrm{HbA}$. With hemoglobin movement- in the appropriate medium-towards the anode, HbS moves more slowly than HbA. Red cell haemolysates were applied to cellulose acetate as alkaline medium with tris-EDTA-borate as buffer system and $\mathrm{Hb}$ separation was obtained by electroforesis for 20 minutes at $350 \mathrm{~V}^{\prime}$.

\section{Determination of $\mathrm{HbF}, " \gamma$ and " $\gamma$ levels}

The $\mathrm{HbF}^{*}$ levels were determined by high-performance liquid chromatography or HPLC ${ }^{2}$. This technique allows complete separation of HbF from other Hb types in less than 50 minutes. The chromatographic procedure was performed on a weak cation exchange resin in a PolyCath A column $(4.6 \times 200 \mathrm{~mm}$ with particle size of $5 \mathrm{~mm}$; PolyLC, Columbia MD, USA) in a Waters HPLC system (Waters Chromatography division, Milford, MA, USA). Two eluents, A and B, were used which contained respectively $35 \mathrm{mM}$ Bis-Tris, $3 \mathrm{mM} \mathrm{NH}_{4}$-acetate, $1.5 \mathrm{mM} \mathrm{KCN}$, $\mathrm{pH} 6.47$ (Developer A) and $35 \mathrm{mM}$ Bis-Tris, $1.5 \mathrm{mM} \mathrm{KCN}, 150 \mathrm{mM}$ Na-acetate, $16.85 \mathrm{mM} \mathrm{NH}_{4}$-acetate, pH 7.0 (Developer B). 50-200 $\mu \mathrm{g} \mathrm{Hb}$ in red cell lysates was applied to the column that was subsequently eluted with a linear gradient of $25: 75(\mathrm{v} / \mathrm{v})$ eluent $A: B$ to $15: 85(\mathrm{v} / \mathrm{v})$ eluent $\mathrm{a}: \mathrm{B}$ in $85 \mathrm{~min}$ at a flow rate of 0.8 
$\mathrm{ml} / \mathrm{min}$. The absorbance of the effluent was continuously recorded at $415 \mathrm{~mm}$.

The different hemoglobins appear in the following order: $\mathrm{HbF}, \mathrm{HbA}, \mathrm{HbA2}$ and HbS. The individual peaks are quantitated (as area $\%$ ) by a data module (Figure V.1).
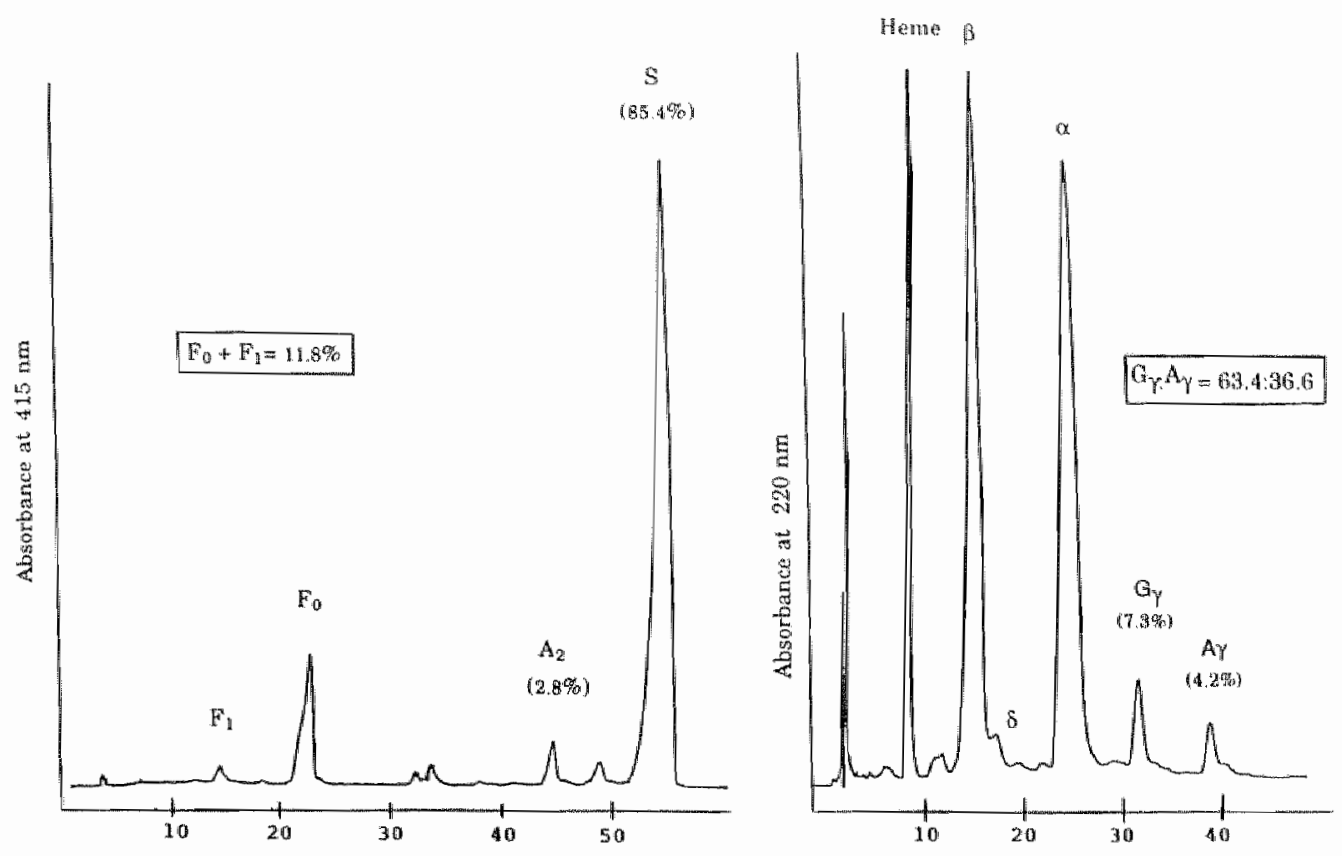

Figure V.1. Quantitation of HbF by HPLC and " $\gamma$ and ${ }^{n} \gamma$ by reversed HPLC procedure in an adult homozygous sickle cell patients. Minor discrepancies in HbF levels between these procedures maty result fron slight contaminations of " $\gamma$ with $c x$ chains. The ratio of ${ }^{6} \gamma$ to ${ }^{A} \gamma(63.4: 36.6)$ in this sample (patient $\left.M A\right)$ retilects the presence of a Senegal gene.

The ${ }^{G} \gamma$ and ${ }^{\wedge} \gamma$ levels were determined in Augusta, GA, USA, by a reversed phase HPLC, using a large -pore Vydac $C_{4}$ column and two water-acetronile-TFA developer as originally described by Shelton et $\mathrm{al}^{3}$ and Kutlar et $\mathrm{al}^{4}$. A low $\mathrm{pH}$ of 2 is chemically established which causes hemoglobin to dissociate in heme and globin chains. The chromatogram was developed by applying $50-800 \mu \mathrm{g} \mathrm{Hb}$ in red cell lysates to the column at a flow rate of $1 \mathrm{ml} / \mathrm{min}$, after having established a gradient of $50: 50(\mathrm{v} / \mathrm{v})$ eluent $\mathrm{A}: \mathrm{B}$ to $30: 70(\mathrm{w} / \mathrm{v})$ eluent a:B. The effluent was continuously recorded at $215 \mathrm{~nm}$ and the peaks were calculated as mentioned above.

Separation of the globin chains depends primarily on differences in their 
hydrophobicities. The globin chains appear in the following sequence: $\beta^{C}, \beta^{\text {s }}, \beta^{\AA}$, $\delta, \alpha,{ }^{\wedge} \gamma^{T},{ }^{\mathrm{C}} \gamma$ and ${ }^{\wedge} \gamma^{\mathrm{I}}$ (Figure $\left.\mathrm{V} .1\right)$.

The ${ }^{\wedge} \gamma$ and ${ }^{A} \gamma{ }^{\top}$ chains are the results of a polymorphism at the aminoacid position 75 of the ${ }^{A} \gamma$ globin chain (Isoleucine-I- for the common ${ }^{A} \gamma$ type and Threonine-Tfor the other Ay type).

The levels of $\mathrm{HbF}\left(={ }^{\mathrm{G}_{\gamma}}+\mathrm{A}_{\gamma}{ }^{\mathrm{S}}+{ }^{\mathrm{A}} \gamma^{\mathrm{T}}\right)$ are calculated as percentage of total $\beta$-like chains $\left(\delta+\beta+{ }^{A}{ }^{T}+{ }^{G} \gamma+A \gamma\right)$.

Samples that contained less than $20 \% \mathrm{HbF}$ in their red cell lysates required an initial enrichment of the HbF fraction. This was done by performing a anion exchange DEAE-cellulose chromatography. Depending upon the $\% \mathrm{HbF}$ in the red cell lysate, $20-60 \mathrm{mg} \mathrm{Hb}$ in the haemolysate were applied to a column $(30 \times 1,5$ $\mathrm{cm}$ ); the chromatogram was developed for 15 minutes at a flow rate of $50 \mathrm{ml} / \mathrm{hour}$. The top of the column containing the HbF fraction was removed and poured into a microcolumn $(7 \times 0.5 \mathrm{~cm})$ and eluted with a stripping buffer ${ }^{5}$.

\section{Determination of $\beta^{s}$ haplotype and $\alpha$-globin gene number}

(Comprehensive Sickle Center, Augusta, GA, USA)

After isolating DNA from white blood cells by the method of Poncz et al ${ }^{6}$, the modified procedure of Southern ${ }^{5,7}$ was used for the determination of the $\beta$-globin gene haplotype and for the evaluation of $\alpha$-globin genes. The gene mapping procedure for the $\beta$-globin gene cluster was done by first digesting the genomic DNA with different restriction enzymes (Hincll, Xmn I, Hind III, Ava II, Hpal, and Bam HI). The resulting DNA fragments were separated by electrophoresis on an agarose gel. Following electrophoresis the DNA in the gel was stained with ethidium bromide and photographed under long wavelength UV light. Then the DNA was depurinated by soaking the gel in $0.1 \mathrm{~N} \mathrm{HCL}$, denatured in a neutralization solution $(3 \mathrm{M} \mathrm{NaCl}, 1.5 \mathrm{M}$ Tris- $\mathrm{HCl}, \mathrm{pH} 7.0)$, transferred to a nylon membrane and baked in a vacuum oven at $70-80^{\circ} \mathrm{C}$. Nexi, the membranes were prehybridized with Flavell modified solution and denatured salmon sperm DNA followed by hybridization using denatured $\alpha^{-32}$-labeled probes. These probes are different fragments of $\beta$ globin gene cluster, previously cloned in plasmid vectors, that hybridize specifically with their complementary DNA sequences. Finally, the membranes were washed until a minimum of background radioactivity was measured (by Geiger counter) and exposed to a Kodak XAR X-ray film. The films were developed by Kodak X-ray film processor and the positions and sizes of the particular sequences of DNA were evaluated.

The entire procedure was followed in the same way to determine the $\alpha$-globin gene number utilising restriction enzymes Eco RI, Bgl II and Bam HI, and a $\alpha$ probe (containing the entire $\alpha$-globin gene), $\zeta$-globin gene probe and $\theta$-globin gene probe. 


\section{Quantitation of adhesion molecules and cytokines}

These were performed in serum by Enzyme Linked Immuno-Sorbent Assays (ELISA) according to the manufacturer's guidelines. Interleukin-6: CLB, Netherlands. Interleukin-3, granulocyte macrophage-colony stimulating factor (GMCSF) and soluble Intercellular Adhesion Mollecule-1 (sICAM-1): Medgenix, Belgium. Soluble Vascular Adhesion Molecule-1 (sVCAM-1), sE-Selectin, sPSelectin, sL-Selectin, soluble IL-6 receptor- $\alpha$ Fibronectin, Erythropoietin and Stem Cell factor: R \& D-systems, UK.

\section{Liver and Spleen scintigraphy}

The reticulo-endothelial function of the patients was determined by injecting intravenously $99 \mathrm{~m}$ Technetium-labelled colloid. Radionuclide images of posterior, lateral and anterior views of the spleen and liver were obtained after 30 minutes. The spleen activity was interpreted as positive (normal or partial visualization) or negative (no visualization). 


\section{References}

1. Schneider RM. Developments in laboratory diagnosis. In: Sickle cell DiseaseDiagnosis, Management, Education and Research, edited by H. Abramson, JF Bertles and DL Wethers, page 230-243, CV Mosby, St Louis, 1973.

2. Bissé $\mathrm{E}$, Wieland $\mathrm{H}$. High performance liquid chromatographic separation of human haemoglobins: Simultaneous quantitation of foetal and glycated haemoglobins. J Chromatogr 1988; 434: 95-110.

3. Shelton JR, Shelton JB, Schroeder WA. High performance liquid chromatographic separation of globin chains on a large-pore $\mathrm{C}_{4}$ column. J liq Chromatography 1984; 7: $1969-1977$.

4. Kurlar F, Kutlar A, Huisman THJ. Separation of normal and abnormal hemoglobin chains by reversed-phase high performance liquid chromatography. J Chromatography 1986; 357: 147.

5. Dimovski A.J. Factors affecting the fetal hemoglobin levels in patients with sickle cell anemia and thalassemia. Thesis, University of Limburg, Maastricht, The Netherlands 1993.

6. Poncz M, Solowiejczyk D, Harpel B, Mory Y, Schwartz E, Surrey S. Construction of human gene libraries from small amounts of peripheral blood: analysis of $\beta$-like globin genes. Hemoglobin 1982; 6: 27.

7. Southern EM. Detection of specific sequences among DNA fragments separated by gel electroforesis. J Mol Biol 1975; 98: 503. 


\section{Chapter VI}

\section{Isobutyramide therapy in patients with sickle cell anemia}

AW Saleh. A van Goethem, R Jansen, HJR Velvis, L-H Gu, THJ Huisman

Am J Hematol 1995:49:244-246 


\section{Abstract}

We have administered Isobutyramide as a suspension over a period of 3 months, from a starting dose of $50 \mathrm{mg} / \mathrm{kg} /$ day up to $150 \mathrm{mg} / \mathrm{kg} / \mathrm{day}$, to four adult sickle cell (SS) anemia patients. The maximum dose was maintained for 3 weeks. The blood counts remained stable and the HbF levels decreased slightly. The Gy levels increased at the end of the trial, suggesting activation of the $\mathrm{G} \gamma$ gene at the highest dose of Isobutyramide. Three patients showed a stable rate of hemolysis, while in one patient, an increase of lactate dehydrogenase occurred. None of the patients experienced pain crisis or organ-specific crisis, but all four complained about mild epigastric burning and a bitter taste. After the first month of treatment one patient complained about intolerable epigasiric discomfort which was relieved by Omeprazole. Another patient complained about increasing dyspepsia in the 12 th week leading to the termination of the trial. Oral Isobutyramide administration does not qualify as an effective treatment of SS patients. 


\section{Introduction}

It is well known that the clinical course of sickle cell (SS) disease is improved in patients with high levels of fetal hemoglobin (HbF)'. Moreover, a study of the natural history of sickle cell disease reveals that any increment in the $\% \mathrm{HbF}$, even at low levels, will have an ameliorating effect ${ }^{2}$. Consequently, clinical research has focused on the pharmacological manipulation of $\mathrm{HbF}$ and $\mathrm{F}$ cells. Chemotherapeutic agents like hydroxyurea can induce $\gamma$ chain synthesis ${ }^{3}$ but pose the risk of cytotoxicity and mutagenicity. Intravenous butyrate, a naturally occurring compound which lacks cytotoxicity, has been reported to stimulate $\mathrm{HbF}$ production $^{4}$, its effect being explained by an action on the promoter of both $\gamma$ globin genes. Butyrate is rapidly metabolized by the liver which limits its use to (prolonged) intravenous administration. Isobutyramide, a derivative of butyrate, has been produced as an oral alternative and has been shown to increase $F$ cell productions. Here we report our preliminary findings about Isobutyramide in a small group of SS patients.

\section{Methods}

Four SS patients, two males and two females, were admitted to the study which was conducted with the approval of the local board of the Food and Drug administration and the ethical board of the St. Elisabeth Hospital, Curaçao, the Netherlands Antilles. Their mean age was 42 years. Three had haplotype $\mathbb{1 9 / 1 9}$, while one carried a hybrid 19 haplotype. All had four $\alpha$-globin genes $(\alpha \alpha / \alpha \alpha)$. All four had been treated with Hydroxyurea in a previous trial, until 3 months before the start of this study. None took any medication other than folic acid, except for one female patient who was on Acenocoumarol because of a liver sequestration crisis 6 months earlier. None experienced symptoms suggesting pain crisis or any organ-specific crisis at the start of the study nor had they received a lransfusion within 6 months of the start of this study.

Isobutyramide was prepared as a suspension, sweetened, and artificially flavored. The patients were treated on an ambulatory basis. After written informed consent was obtained, Isobutyramide was administered starting at a dose of $50 \mathrm{mg} / \mathrm{kg} / \mathrm{day}$ and was increased to $150 \mathrm{mg} / \mathrm{kg} /$ day over a period of 3 months. The maximum dose was maintained for 3 weeks. Blood counts, reticulocytes, lactate dehydrogenase (LDH), bilirubin, $\mathrm{HbF}$, and ${ }^{\mathrm{G}} \gamma$ levells were assessed at weekly intervals. HbF was quantitated by high performance liquid chromatography $(\mathrm{HPLC})^{6}$ and the ${ }^{\mathrm{G}} \gamma$ levels by reversed phase HPLC ${ }^{7}$. Patients were visited at home once a week, at which time compliance was evaluated and symptoms or complaints were noted. 


\section{Results and discussion}

During the entire study the hematological data remained the same (some are listed in table VI.1). A slight decrease in HbF was noted which may well reflect the residual effect of Hydroxyurea which was given as a part of another trial and was stopped 3 months prior to the start of this study. The ${ }^{\sigma} \gamma$ levels remained essentially unchanged at first, suggesting no preferential activation of $\gamma$ genes. However, at the highest dose ( $150 \mathrm{mg} / \mathrm{kg} /$ day) of Isobutyramide an increase in ${ }^{\circ} \gamma$ was observed in all patients (Figure VI.1). Because of increasing complaints of epigastric discomfort the study was terminated after 3 months, making it impossible to evaluate if the level of ${ }^{\circ} \gamma$ gene activation would result in a significant increase in HbF. Three patients showed stable LDH levels and reticulocyte counts (Table VI.1). Patient $A$ showed a slight increase of $L D H$ and in reticulocytes at the highest dose of Isobutyramide due to an increase in the rate of hemolysis, which was likely caused by a direct (toxic?) effect of the Isobutyramide, since signs of infection or vaso-occlusive episodes were not observed. Kidney function and liver parameters remained unaffected during the study. None of the patients experienced a pain crisis or other vaso-occlusive episodes. Two patients did not have any undesirable symptoms other than some epigastric burning and a bitter taste in the mouth at the time of ingestion of the drug. Patient $C$ complained about intolerable epigastric discomfort after 1 month. He refused endoscopy and was given Omeprazole (20 $\mathrm{mg}$ twice/day) with good results. Patient A developed an increasing dyspepsia in the 12 th week of the study.

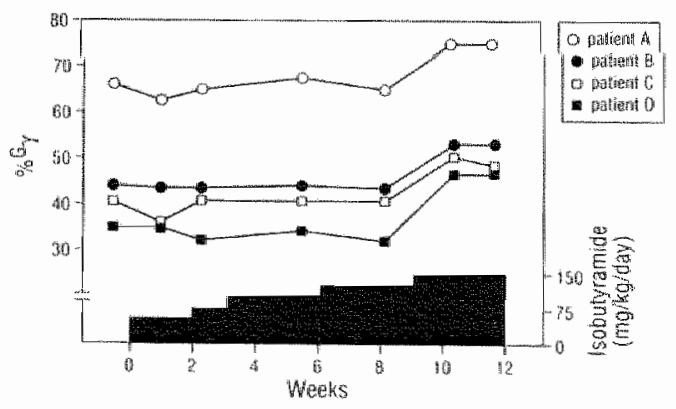

Figure VI.l The relative levels of " $\gamma$ chain (in $\%$ of total $\gamma$ ) in four SS patients treated with oral lsobutyramide.

We conclude that oral Isobutyramide may activate the ${ }^{\mathrm{a}} \gamma$-globin genes in vivo at extremely high doses but the effect appears to be weak at best. The use of oral Isobutyramide as "monotherapy" in SS patients has no clinical value but it may be 
that the use of Isobutyramide in combination with other drugs will be more effective in stimulating $\gamma$ chain production.

Table VI.1 Laboratory Data for Four SS Patients Treated With Isobutyramide

\begin{tabular}{|c|c|c|c|c|c|c|c|c|}
\hline Patient & $\begin{array}{l}\text { Age } \\
\text { (yrs) }\end{array}$ & $\begin{array}{c}\text { Dose } \\
\text { (mg/kg/day) }\end{array}$ & $\begin{array}{c}\mathrm{Hb} \\
(\mathrm{g} / \mathrm{dl})\end{array}$ & $\begin{array}{l}\mathrm{PCV} \\
(1 / 1)\end{array}$ & $\begin{array}{l}\mathrm{RBC} \\
\left(10^{2 / 2} / 1\right)\end{array}$ & $\begin{array}{c}\mathrm{HbF} \\
(\%)\end{array}$ & $\begin{array}{c}\text { Retics } \\
\left(1,000 / \mathrm{mum}^{3}\right)\end{array}$ & $\begin{array}{l}\text { LDH } \\
(\mu / 1)\end{array}$ \\
\hline \multirow[t]{4}{*}{ A } & \multirow[t]{4}{*}{46} & 0 & 8.8 & 0.260 & 2.38 & 17.0 & 274 & 386 \\
\hline & & $50^{\circ}$ & 8.6 & 0.265 & 2.38 & 14.8 & 350 & 422 \\
\hline & & $100^{b}$ & 8.6 & 0.252 & 232 & 15.6 & 260 & 416 \\
\hline & & $150^{6}$ & 8.8 & 0.266 & 2.45 & 15.4 & 343 & 501 \\
\hline \multirow[t]{4}{*}{$B$} & \multirow[t]{4}{*}{35} & 0 & 7.8 & 0.233 & 2.58 & 10.7 & 464 & 633 \\
\hline & & $50^{\mathrm{B}}$ & 9.6 & 0.290 & 3.08 & 8.8 & 400 & 709 \\
\hline & & $100^{\circ}$ & 9.6 & 0.272 & 3.03 & 9.3 & 336 & 817 \\
\hline & & $150^{\mathrm{b}}$ & 9,5 & 0.275 & 3.09 & 8.3 & 569 & 572 \\
\hline \multirow[t]{4}{*}{$\mathrm{C}$} & \multirow[t]{4}{*}{56} & 0 & 5.9 & 0.171 & 1.77 & 6.3 & 246 & 1.099 \\
\hline & & $50^{\mathrm{n}}$ & 5.6 & 0.172 & 1.70 & 5.7 & 207 & 1.103 \\
\hline & & $100^{\mathrm{b}}$ & 5.9 & 0.174 & 1.86 & 4.1 & 285 & 1.197 \\
\hline & & $150^{\circ}$ & 5.6 & 0.172 & 1.83 & 3.2 & 271 & 992 \\
\hline \multirow[t]{4}{*}{$\mathrm{D}$} & \multirow[t]{4}{*}{31} & 0 & 7.0 & 0.206 & 2.32 & 4.2 & 432 & 933 \\
\hline & & $50^{\circ}$ & 7.3 & 0.222 & 2.44 & 3.9 & 310 & 909 \\
\hline & & $100^{\mathrm{b}}$ & 7.9 & 0.222 & 2.55 & 2.6 & 268 & 975 \\
\hline & & $150^{1 x}$ & 7.5 & 0.225 & 2.59 & 2.6 & 518 & 1.016 \\
\hline
\end{tabular}




\section{Rererences}

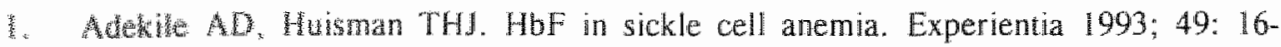
t.7.

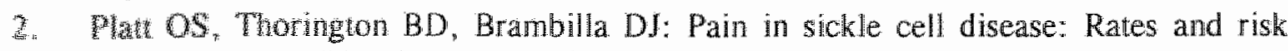
Wonts. N Eng J Med 1991; 5:11-16.

3. Rougers GP, Dover GJ, Noguchi CT, Schechter AN, Nienhuis AW. Hematologic responses of patients with sickle cell disease to treatment with hydroxyurea. $\mathrm{N}$ Engl Med $1990: 322: 1037-1045$.

4. Werne SP, Ginder GD, Faller DV, Dover GJ, Ikuta T, Witkowska HE, Cai SP, Vichnsky $\mathrm{E}$, Oliwieri $\mathrm{N}$. A short-term trial of butyrate to stimulate fetal globin gene expression in the beta-globin disorders. $N$ Engl J Med 1993; 328: 81-86.

5. Costin D, Dover $G$, Olivieri $N$, Beutler $E$, Walsh CT, Torkelson $S$, Pantazis $C$, Brauer M, Faller DV, Perrine SP. Clinical use of the butyrate derivative Isobutyramide in the $\beta$-globin disorders. Blood 1993; 82 (suppl 1): 357a (abstract).

6. Bissé $\mathrm{E}$, Wieland $\mathrm{H}$. High performance liquid chromatographic separation of human haemoglobins: Simultaneous quantitation of foetal and glycated haemoglobins. I Chromatogr 1988;434:95-110.

7. Shelton JR, Shelton JB, Schroeder WA. High performance liquid chromatographic separation of globin chains on a large- pore C4 column. J liq Chromatogr $1984 ; 7$ : $1969-1977$. 


\section{Chapter VII}

\section{Hydroxyurea therapy in sickle cell anemia patients in Curaçao, the Netherlands Antilles}

AW Saleh, HJR Velvis, LH Gu, HFP Hillen, THJ Huisman

Acta Haematol 1997;98:125-129 


\begin{abstract}
We have treated nine patients with sickle cell anemia (SS) with hydroxyurea (HU). All nine patients carried four $\alpha$-globin genes and the $\beta^{s}$-globin haplotypes 19/19 (Benin/Benin), except for one who had haplotype \#19 together with type \#3 (Benin/Senegal). Six patients received HU for 10 months and were again treated with the drug for five months after an intermission of one year. One patient was given HU for 22 consecutive months. A record was kept of hematological and biochemical data, $\mathrm{HbF}$ and $\sigma y$ levels, as well as possible clinical complications. Our data show that HU generally improves the hematological and biochernical values and the level of $\mathrm{HbF}$, and reduces painful crises in some patients. However, although the clinical symptoms ameliorate in some patients during HU therapy, the older patients did not observe changes in their general condition; the same is the case for the patient with haplotype 19/3. One patient also experienced a life-threatening liver sequestration during treatment. We conclude that the selection of patients who may benefit from HU therapy needs further evaluation.
\end{abstract}




\section{Introduction}

Clinical surveys conducted during the past decade show that SS patients apparently have a milder disease when their fetal hemoglobin (HbF) level is increased ${ }^{1.2}$. Consequently, the question has been raised: Would a pharmacological induction of $\mathrm{HbF}$ production in SS patients ameliorate their disease? Hydroxyurea (HU), a cytostatic agent, has been shown to increase $\mathrm{HbF}$ levels ${ }^{3-6}$. The mechanism of action of $\mathrm{HbF}$ induction, although not fully elucidated, is perhaps explained by a cytotoxic action on cycling erythroblasts with preferential survival of non-cycling erythroid progenitors which may undergo accelerated differentiation and maturation. These precursors have an enhanced capacity for $\gamma$-globin synthesis. A definitive insight into the mechanisms of the effect of $\mathrm{HU}$ on letal erythropoiesis is still lacking. Apart from the action on $\mathrm{HbF}$ production HU induces macrocytosis and improves cell deformability as well as the hydration status of erythroid cells?

A recent multicenter trial of $\mathrm{HU}$ in nearly 300 patients with SS in the United States ${ }^{8}$ showed that this drug can ameliorate the clinical course in some adult patients. Painful crises, chest syndrome, and the requirement for blood tranfusion were significantly decreased, while no differences were found in stroke events, hepatic sequestration crises, or mortality. The most important side effect was myelosuppression which occurred in almost all patients but this did not give rise to any serious complications. No deaths could be attributed to the HU treatment. Still, questions remain concerning the teratogenic and carcinogenic potential of $\mathrm{HU}$, its effects on growth and development in children, and the long-term effect of $\mathrm{HU}$ on progression of organ damage and mortality.

We have studied the hematological and clinical effects in response to HU treatment in adult SS patients during a 10-month period (from august 1992 till june 1993). After one year without HU the same patients, except two, were again treated with HU for a period of five months. One patient was treated for 22 consecutive months. Our data show that HU improves hematological and biochemical values in most patients during both treatment periods. However, although clinical symptoms ameliorated in some patients, others did not observe an improvement in their general condition, and one patient experienced a life-treatening liver sequestration.

\section{Methods}

Eight patients, four males and four females and ranging in age from 201058 years (mean $38 \mathrm{yrs}$ ), participated in the study. Each patient had four $\alpha$-globin genes $(\alpha \alpha / \alpha \alpha)$, had their $\beta^{s}$ haplotypes determined, and expressed different levels of disease severity. Detailed explanation of the study and possible effects of $\mathrm{HU}$ treatment were given on two successive visits in the presence of a relative. At the 
second visit all patients gave their written consent. The study was conducted with the approval of the Ethical Board of the St. Elisabeth Hospital, Curaçao, The Netherlands Antilles. Before starting the HU therapy, base line $C B C$ values, reticulocyte counts, lactate dehydrogenase (LDH), unconjugated bilirubin, kidney function, $\mathrm{HbF}$ and ${ }^{\mathrm{G}} \gamma$ levels, were determined. $\mathrm{HbF}$ was quantitated by cation exchange high performance liquid chromatography (HPLC) ${ }^{9}$ and the ${ }^{6} \gamma$ levells by reversed phase HPLC ${ }^{10}$. None of the patients took any medication other than folic acid. Iron levels were measured and patients were given an iron supplement if considered necessary. Pregnancy was ruled out. Creatinin clearance of each patient was within normal $\|$ imits and none of the patients was addicted to narcotics.

After the start of HU treatment, the various blood tests were done at least twice a month. Patients were ambulatory and visited the policlinic twice a month at which time compliance was evaluated and symptoms and complaints were registered. Painful crises were defined as severe pains in the bones of the extremities, back, abdomen or chest which were not relieved by non-narcotic analgesics $(500 \mathrm{mg}$ acetaminophen); some made a hospital admission necessary. During the second treatment period, radio isotope (technetium) scans of the liver and spleen were made before and after five months of therapy. The starting dose of HU in the first treatment period was $15 \mathrm{mg} / \mathrm{kg} /$ day, to be taken during four consecutive days a week. The dose was increased by $5 \mathrm{mg} / \mathrm{kg} /$ day at four- week intervals until bone marrow suppression or other significant side effects appeared, or to a maximum of $30 \mathrm{mg} / \mathrm{kg} / \mathrm{day}$. In the event of bone marrow suppression (absolute reticulocyte count $<40,000$ per $\mathrm{mm}^{3}$, a leucocyte count $<4000$ per $\mathrm{mm}^{3}$ or a platelet count $<150,000$ per $\mathrm{mm}^{3}$ ) the dose was adjusted downward with $5 \mathrm{mg} / \mathrm{kg} / \mathrm{day}$. In the second treatment period most patients were started and maintained on the ideal dosage determined during the first treatment period.

\section{Patients (Table VII.1)}

All participants, except for patient $E$ and $H$, carried haplotype $\# 19$ on each chromosome (19/19 or Benin/Benin) as well as four $\alpha$-globin genes $(\alpha \alpha / \alpha \alpha)$. Patient $\mathbb{E}$ was found to have a combination of haplotypes $\# 19$ and $\# 3$ (19/3 or Benin/Senegal) with four $\alpha$-globin genes. Patient $H$ carried a combination of Haptolypes $\$ 19$ and $\# 20$ (Benin/Bantu) and had a normal number of $\alpha$-globin genes. Patient A, a 58 -year-old male, has a remarkably benign clinical disease. He had peptic ulcer disease 3 years before the study but has not experienced a painful crisis for over two decades. He is employed as a bus driver. Patient B, a 33-yearold female, has been admitted to the hospital about twice a year for pain crises. She frequently complains about pain in her lower abdomen possibly due to minor intestinal crises or irritable bowel syndrome. Ultrasound examination and colonoscopy did not detect any abnormalities. Patient $C$, a 37-year-old male, experienced approximately two painful crises a year during the previous five years, 
but is otherwise well. Patient D, a 37-year-old female, has had two painful crises during the past five years, cholecystectomy in 1988 and ecclampsia with birth of a premature but healthy infant in 1987 . Patient $\mathrm{E}$, a 48 -year-old female, was free of pain crises for over 15 years and is in good general condition.

Patient $F$, a 20-year-old male, has an average of three painful crises per year but no other complications. Patient $G$, a 41 -year-old female, experienced only two painful crises during the past 10 years. However, she did receive a total of 12 transfusions due to hemolytic crises, in conjunction with an otherwise uncomplicated delivery and cholecystectomy for symptomatic cholelithiasis. The latter occurred one month prior to the HU treatment. Patient $\mathrm{H}$, a 35-year- old male, suffered about two painful crises per year over the past 10 years, localised in either his extremities and back or abdomen. During this period he was hospitalized once for acute chest syndrome and has been treated on an ambulatory basis for leg ulcer. He has not been able to maintain full-time employment. The history of patient I, a 31-year-old female, who participated in the second phase of the HU treatment only, reveals a relatively low hemoglobin level secondary to chronic hemolysis and possibly aplastic crisis. She received 23 units of blood during the past 15 years. She had chronic ulcers on both legs for over one year prior to the HU treatment but did not experience any painful crisis during the previous years.

Table VII.1 Laboratory data for 8 SS patients treated with HU during the first phase of the study

\begin{tabular}{|c|c|c|c|c|c|c|}
\hline $\begin{array}{l}\text { Patient } \\
\text { sex-age }\end{array}$ & $\begin{array}{l}\text { Months } \\
\text { of } R_{x}\end{array}$ & $\underset{\mathrm{mg} / \mathrm{kg} / \mathrm{day}}{\mathrm{HU}^{\mathrm{s}}}$ & $\begin{array}{c}\mathrm{Hb} \\
\mathrm{g} / \mathrm{dl}\end{array}$ & $\begin{array}{c}\mathrm{MCV} \\
\mathrm{fl}\end{array}$ & $\begin{array}{c}\mathrm{HbF} \\
\%\end{array}$ & $\%$ \\
\hline A & $\begin{array}{r}0 \\
10\end{array}$ & $\begin{array}{r}0 \\
15\end{array}$ & $\begin{array}{l}6.1 \\
7.3\end{array}$ & $\begin{array}{l}101 \\
118\end{array}$ & $\begin{array}{r}6.0 \\
20.7\end{array}$ & $\begin{array}{l}40.9 \\
47.0\end{array}$ \\
\hline $\begin{array}{l}B^{2} \\
F-33\end{array}$ & $\begin{array}{r}0 \\
10\end{array}$ & $\begin{array}{r}0 \\
20\end{array}$ & $\begin{array}{l}7.2 \\
8.4\end{array}$ & $\begin{array}{r}85 \\
104\end{array}$ & $\begin{array}{r}2.3 \\
11.0\end{array}$ & $\begin{array}{l}34.5 \\
40.2\end{array}$ \\
\hline$C_{M-37}$ & $\begin{array}{r}0 \\
10\end{array}$ & $\begin{array}{r}0 \\
30\end{array}$ & $\begin{array}{l}10.1 \\
10.9\end{array}$ & $\begin{array}{r}89 \\
101\end{array}$ & $\begin{array}{r}8.8 \\
18.4\end{array}$ & $\begin{array}{l}39.2 \\
44.0\end{array}$ \\
\hline $\begin{array}{l}D \\
F-37\end{array}$ & $\begin{array}{r}0 \\
10\end{array}$ & $\begin{array}{r}0 \\
30\end{array}$ & $\begin{array}{l}9.1 \\
9.9\end{array}$ & $\begin{array}{r}90 \\
113\end{array}$ & $\begin{array}{l}10.3 \\
19.7\end{array}$ & $\begin{array}{r}43.8 \\
42.4\end{array}$ \\
\hline $\begin{array}{l}\mathbb{E}^{3} \\
\mathrm{~F}-48\end{array}$ & $\begin{array}{r}0 \\
10\end{array}$ & $\begin{array}{c}0 \\
17.5\end{array}$ & $\begin{array}{r}7.8 \\
10.1\end{array}$ & $\begin{array}{l}103 \\
120\end{array}$ & $\begin{array}{l}13.4 \\
21.7\end{array}$ & $\begin{array}{l}63.6 \\
67.0\end{array}$ \\
\hline $\mathrm{F}-20$ & $\begin{array}{r}0 \\
10\end{array}$ & $\begin{array}{r}0 \\
30\end{array}$ & $\begin{array}{l}8.6 \\
9.8\end{array}$ & $\begin{array}{r}89 \\
102\end{array}$ & $\begin{array}{r}5.0 \\
12.3\end{array}$ & $\begin{array}{l}33.2 \\
34.3\end{array}$ \\
\hline $\begin{array}{l}\mathrm{G}^{2} \\
\mathrm{~F}-41\end{array}$ & $\begin{array}{r}0 \\
22\end{array}$ & $\begin{array}{r}0 \\
25\end{array}$ & $\begin{array}{l}6.11 \\
7.5\end{array}$ & $\begin{array}{l}102 \\
123\end{array}$ & $\begin{array}{r}2.7 \\
10.4\end{array}$ & $\begin{array}{l}34.3 \\
31.1\end{array}$ \\
\hline $\begin{array}{l}\mathrm{H}-35 \\
\mathrm{M}\end{array}$ & $\begin{array}{r}0 \\
10 \\
\end{array}$ & $\begin{array}{r}0 \\
30 \\
\end{array}$ & $\begin{array}{l}7.6 \\
8.9 \\
\end{array}$ & $\begin{array}{l}84 \\
93 \\
\end{array}$ & $\begin{array}{l}1.3 \\
5.2 \\
\end{array}$ & $\begin{array}{l}42.2 \\
40.2\end{array}$ \\
\hline
\end{tabular}

All patients were homozygous for $\beta^{S}$ haplotype 19 , except patient $E$ who was $19 / 3$ and patrent $H$ who was 19/20. All had four $\alpha-$ globin genes.

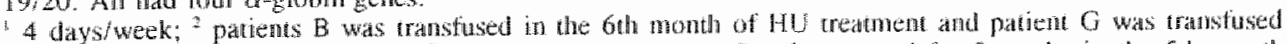
one month prior to HU ireament; "Hu increased to $25 \mathrm{mg} / \mathrm{kg}$, interrupied for 2 weeks ing the 5 th month and reintroduced at a dose of $17.5 \mathrm{mg} / \mathrm{kg} / \mathrm{day}$. 


\section{Results}

\section{Dosage}

During the first treatment period the dosage for patients $C, D, F$ and $H$, was monthly increased to $30 \mathrm{mg} / \mathrm{kg} / \mathrm{day}$ (average $1,500 \mathrm{mg} /$ day) for four days a week, without signs of bone marrow suppression. The dosages in patients $A, B$ and $G$ were not increased beyond 15,20 , and $25 \mathrm{mg} / \mathrm{kg} / \mathrm{day}$, respectivelly, since a doubling of the HbF level was observed at these dosages. Patient E developed recurrent epistaxis (without trombocytopenia) after four months. HU treatment was interrupted for 2 weeks and subsequently restarted and maintained at 17.5 $m g / k g / d a y$. Except for patient $\mathrm{G}$, all patients were treated for 10 months during the first trial period. Patient $G$ received uninterrupted HU treatment for up to 24 months. Patient $C$ was lost to follow-up after the first trial.

In the second treatment phase patients B, D, F, H and I were prescribed a daily dosage of $20 \mathrm{mg} / \mathrm{kg}$ ( $=1,000 \mathrm{mg} / \mathrm{day}$ ) of HU for seven days a week. Patients A and $E$ were respectively given 15 and $17.5 \mathrm{mg} / \mathrm{kg} / \mathrm{day}$ ( $=1,000 \mathrm{mg} / \mathrm{day}$ ) of $\mathrm{HU}$ for four days a week. Patients $\mathrm{F}$ and $\mathrm{H}$ admitted that they did not take their medication on a regular basis during the second treatment phase. Therefore, we did not include their results obtained during this period.

\section{Mematologic and Biochemical Responses (Tables VII.1 and VII.2)}

All patients, except for patient $\mathrm{F}$ and $\mathrm{H}$, revealed an increase in $\mathrm{MCV}$ and total $\mathrm{Hb}$ level during both treatment periods. The lack of compliance by patients $\mathrm{F}$ and $\mathrm{H}$ during the second treatment phase was confirmed by the absence of increases in their MCV values and HbF levels. In most patients reticulocytes decreased during first and second treatment phases, which was more likely due to HU- induced cytotoxicity than lessened hemolysis, for LDH levels showed no consistent pattern of change. No thrombocytopenia or neutropenia occurred. Patient B developed abnomal livertests during the lirst treatment period as a consequence of a liver sequestration crisis. None of the other patients showed abnormalities in kidney or liver function. During the first trial, the levels of HbF increased in all patients $2-10$ 5 - fold and returned to base line between trials. The increase in HbF levels during the second treament period appeared earlier in most individuals, while the values in patients $A, B$ and $E$ were higher than in the first trial.

Patient. $\mathbb{E}$ had a ${ }^{\circ} \gamma$ level that was wice that of the other patients which can be

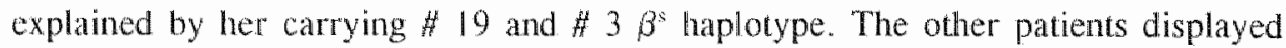
some inter-individual difference in the ${ }^{G} \gamma$ values (from -32 to 44\%) which remained remarkably constant, implying that no preferential activation of the $\gamma$ genes occurred (Table VII.1). 
Table VII.2 Laboratory data for 7 SS patients who participated in the second phase of the HU therapy

\begin{tabular}{|c|c|c|c|c|c|}
\hline $\begin{array}{l}\text { Patient } \\
\text { sex-age }\end{array}$ & $\begin{array}{c}\text { Months } \\
\text { of } \mathbf{R}_{x}\end{array}$ & $\begin{array}{c}\mathrm{HU}^{\mathrm{k}} \\
\mathrm{mg} / \mathrm{kg} / \mathrm{day}\end{array}$ & $\begin{array}{l}\mathrm{Hb} \\
\mathrm{g} / \mathrm{d} / \mathrm{bl}\end{array}$ & $\begin{array}{c}\mathrm{MCV} \\
\mathrm{f}\end{array}$ & $\underset{s}{\mathrm{HbF}}$ \\
\hline A & 0 & 0 & 5.1 & $9 !$ & 6.2 \\
\hline$M-58$ & 5 & 15 & 6.9 & 124 & 26.3 \\
\hline $\mathrm{B}$ & 0 & 0 & 8.2 & 84 & 2.5 \\
\hline$F-33$ & 5 & 20 & 9.0 & 113 & 17.1 \\
\hline$D$ & 0 & 0 & 8.3 & 95 & 12.4 \\
\hline$F-37$ & 5 & 20 & 8.9 & 103 & 14.5 \\
\hline$E$ & 0 & 0 & 8.3 & 108 & 12.9 \\
\hline$F-48$ & 5 & 17.5 & 9.5 & 130 & 29.5 \\
\hline$F$ & 0 & 0 & 9.7 & 95 & 6.8 \\
\hline$M-20$ & 5 & 20 & 7.8 & 94 & 7.5 \\
\hline $\mathrm{H}$ & 0 & 0 & 7.9 & 79 & 1.5 \\
\hline M-35 & 5 & 20 & 8.0 & 84 & 1.4 \\
\hline 1 & 0 & 0 & 5.2 & 93 & 4.3 \\
\hline$F-31$ & 5 & 20 & 7.2 & 131 & 25.2 \\
\hline
\end{tabular}

'Patient $\mathrm{A}$ and $\mathrm{B}$ were treated with HU for 4 days/week, others for 7 days/week.

\section{Clinical responses}

Patients $A, C$ and $D$, who were known to have relative mild SS disease, did not show any change in their clinical condition during treatment. Patient $B$ was admitted to the hospital twice during the first four months of treatment because of painful crises. In the sixth month, she experienced a third painfull episode which was complicated by a liver sequestration crisis (Figure VII.1).

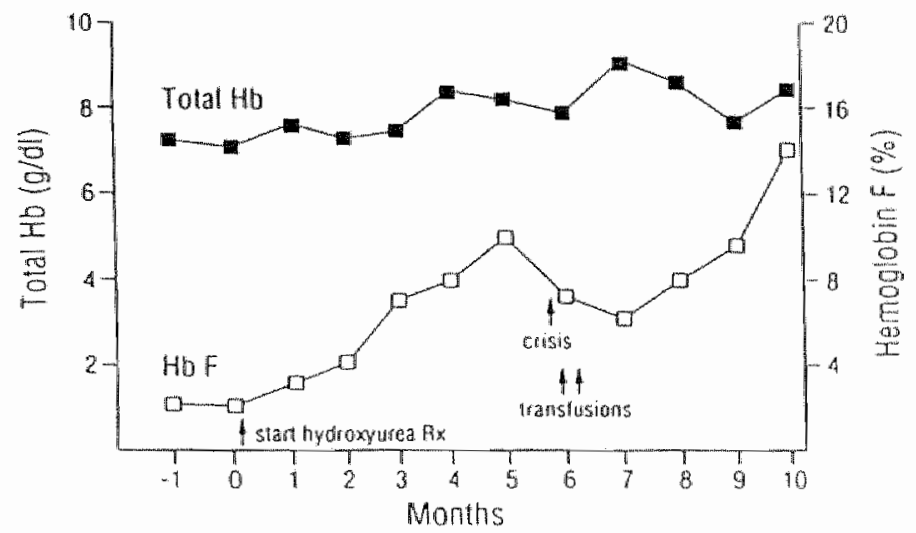

Figure VIl.1 Response to HU therapy in Patient B experiencing a life-treatening liver sequestration crisis. 
Because of this life-treatening situation she was transfused with two units of packed. cells, and intravenous heparin was administered, followed by oral acenocoumarol. she recovered completely. In between trials she was seen twice because of pain crises in the extremities not responding to non-narcotic analgesics. She also developed complains of dyspnea on exertion which was attributed to mild high output failure; she was treated with diuretics and digoxin. As before, she continued to complain about regular cramping pains in her abdomen; these symptoms were treated symptomatically. During the second treatment phase she only complained about occasional dysmenorrea. Patient $E$ maintained a mild course without painfull crises or other vaso-occlusive complications but experienced recurrent epistaxis four months into the first trial. The epistaxis was believed to be HU related and possibly caused by local hyperemia. Examination of the nasal passage revealed no other abnormalities. After interruption and reintroduction of the HU treatment at a lower dose, epistaxis did not reoccur. Patient $F$ did not have any painfull crisis or other specific symptoms during the 10 months of HU treatment. Patients $\mathrm{G}, \mathrm{H}$ and l experienced some improvement in their endurance, probably due to the increase in their total Hb level. Patient $\mathrm{H}$ resumed full-time employment, and again complained of lack of energy in the year following the first trial. Also, one of the chronic ulcers seen in patient I was healed and another became considerably smaller during $\mathrm{HU}$ treatment al though topical ointments remained unchanged. We did not detect spleen activity on isotope scanning which suggests that the lost splenic function in adult SS patients was not significantly restored during five months of HU treatment.

None of our patients complained about adverse symptoms related to the ingestion of HU, nor did any of them show a pre-malignant or malignant disorder. However, it should be noted that the course of treatment was still relatively short.

\section{Discussion}

Earlier studies as well as the one reported here show that some patients do benefit from treatment with HU because of a reduction in painful crises. Several patients expressed improvement of endurance and were able to keep up their job requirements. It remains impossible to predict which patient will respond favorably to $\mathrm{HU}$. The $\mathrm{MCV}$ value is useful in determining proper compliance but, although in most instances it correlates with the $\mathrm{HbF}$ level, the magnitude of the HbF response cannot be estimated from the increase in $\mathrm{MCV}$ value. Increase in $\mathrm{MCV}$ aswell as HbF levels does not lead to significant clinical amelioration in all patients. Patients above 37 years of age who participated in our study appear not to benefit substantially from this therapy. Major vaso-occlusive complications, except for the chest syndrome, are not prevented and, in some cases may even have been 
provoked by $\mathrm{HU}^{11}$. Individuals carrying the Asian and Senegal $\beta^{s}$-globin haplotypes ${ }^{12-14}$ as well as SS patients with an additional $\alpha$ thalassemia ${ }^{15.16}$ are known to exhibit clinically milder disease, have a better prognosis, and can be expected to benefit less from HU therapy.

These facts should caution against non-selective administration of HU to SS patients. Furthermore, although HU therapy has not revealed an increase in secondary malignancies ${ }^{17}$, data after long- term use of this drug are not yet available. Not much is known about it's possible teratogenic effect and hence prescribing HU to patients of reproductive age still demands appropriate precautions.

In addition to the effects on bonemarrow and cellular hydration, hydroxyurea has been reported to have significant effects on vascular endothelial cells in vitro ${ }^{18}$. This indicates that the ultimate clinical effect of $H U$ is certainly not solely dependent on changes in hematologic profile and $\mathrm{HbF}$ and $\mathrm{F}$ - cell response, but also on factors involved in the mechanisms of adhesion of bloodcells to vascular endothelium. Recent studies have shown that cytokines, endothelium, and soluble adhesion molecules aswell as their membrane-integrated counterparts on blood cells play an important role in the mechanism of vaso-occlusive crisis ${ }^{19 \cdot 23}$. Changes in the activity of specific adhesive processes may therefore be an additional measure of the clinical response to $\mathrm{HU}$ (and other therapeutic compounds). We conceive that carefull measurement of the activity of steady state adhesive processes aswell as taking into concern patient's age, $\beta^{\mathrm{S}}$-globin haplotype or presence of concomittant $\alpha$-thalassemia could enable selection of SS individuals who will truly benefit from therapy. 


\section{References}

1. Adekile AD. Huisman THJ: HbF in sickle cell anemia. Experientia 1993; 49:16-27.

2. Platt OS, Thorington BD, Brambilla DJ: Pain in sickle cell disease: Rates and risk factors. N Engl J Med 1991; 325: 11-16.

3. Charache $S$, Dover $G$, Moyer M, Moore J. Hydroxyurea - induced augmentation of fetal hemoglobin production in patients with sickle cell anemia. Blood 1987: 69: $109-16$.

4. Sumoza A, Bissoti RS. Treament of sickle cell anemia with hydroxyurea: results in twenty-six paticnts. Blood 1986; 68:67a.

5. Plat $O$, Orkin S, Dover $G$, Beardsley $P$, Miller B. Hydroxyurea enhances fetal hemoglobin production in sickle cell anemia. J Clin Invesit 1987; 74: 652 - 656.

6. Rodgers GP. Dover GI, Noguchi CT, Schechter AN, Nienhuis AW. Hematologic responses of patients with sickle cell disease to treatment with hydroxyurea. $N$ Engl J Med 1990; 322: 1037-1045.

7. Ballas SK, Dover GJ, Charache S. Effect of hydroxyurea on the rheological properties of sickle erythocytes in vivo. Am J Hematol 1989; 32: 104-111.

8. Charache S, Terrin ML, Moore RD, Dover GJ, Barton DB, Eckert SV, McMahon RP. Bonds DR, and the Investigators of the Multicenter Study of Hydroxyurea in Sickle Cell Anemia. Effect of Hydroxyurea on frequency of painful crises in Sickle Cell Aremia. N Engl I Med 1995; 332: 1317-1322.

9. Bissé E, Wieland H. High performance liquid chromatographic separation of human haemoglobins: Simultaneous quantitation of foetal and glycated haemoglobirs. I Chromatogr 1988:434: 95-110.

10. Shelton IR, Shelton JB, Schroeder WA. Hugh performance liquid chromatographic separation of globin chains on a large- pore $\mathrm{C}_{4}$ column. I liq Chromatogr 1984; 7 : 19691977 .

11. Vichinsky EP, Lubin BH. A cautionary note regarding hydroxyurea in sickle cell diseases. Blood 1994; 83: $366-372$

12. Perrine RP. Pembrey ME, John P, Perrine S, Shoup F. Natural history of sickle cell anemia in Saudi Arabs: a study of 270 subjects. Anm Intern Med 1978;88:1-6.

13. Hatori $Y$, Kutlar F, Kutlar A, Mc Kie VC, Huisman THJ. Haplotypes of $\beta^{s}$ chromosonies among patients will sickle cell anemia from Georgia. Hemoglobin $1986 ; 10: 623-642$.

14. Nagel RL. Rao SK, Dunda-Belkodja O. Comolly M M, Fabry ME, Georges A. Krishumoorthy $R$, Labie $D$. The hematological characteristics of sickle cell anemia bearing the Bantu haplotype: The relationship between $\mathrm{G} \gamma$ and Hemoglobin $F$ levels. Blood 1987; 69: 1026-1030.

15. Embury SH. Dozy AM, Miller J, Davis JR, Kleman KM, Preisler H, Vichinsky E, Lande WN, Lubin BH. Kan YW. Mentzer WC. Concurrent sickle cell anemia and alpha thalassemia: effect on severity of anemia. N Engl J Med 1982; 306:270-274. 
16. Stemberg MH, Rosenstock W, Coleman MB, Adams JG. Platica O, Cedeno M. Rieder RF, Wilson IT, Milner P, West S. Effects of thatassemia and microcytosis on the hematologic and vaso-occlusive severity of sickle cell anemia. Blood 1984; 63: $1353-1360$.

17. Berk PD, Goldberg JD, Donovan PB, Fruchtman SM, Berlin NI, Wasserman LR. Therapeutic recommendations in polycythemia vera based on Polycythemia Vera Study Group protocols. Semin Hematol 1986; 23: 132-143.

18. Adragna NC, Fonseca P, Lauf PK. Hydroxyurea affects cell morphology, cation transport, and red blood cell adhesion in cultured vascular endothelial cells. Blood 1994; 82: 553-560.

19. Pieters RC, Rojer RA, Saleh AW, Saleh AEC, Duits AJ. Molgramostim to treat SS- sickle cell leg ulcers. The Lancet 1995; 345, no 8948: p 528.

20. Saleh AW, Pieters RC, Duits AJ. rhGin-CSF (Molgramostim): A potent inducer of sickle cell vaso-occlusive crisis. Abstract for the 20th Anmul Meeting. National Sickle Cell Disease Program, March 1995, Philadelphia, USA

21. Francis RB, Haywood LJ. Elevated immunoreactive tumor necrosis factor and interleukin-1 in sickle cell disease. J Natl Med Assoc 1992; 84: 611-615.

22. Swerlick RA, Eckman JR, Kumar A, Jeitler M, Wick TM, a4bl-lntergtin expression on sickle reticulocytes: vascular cell adhesion molecule- 1 dependent binding to endothelium. Blood 1993; 82: 1891- 99.

23. Duits AJ, Pieters RC, Saleh AW, Rosmalen van E, and Rojer RA. Enhanced levels of soluble VCAM-1 in sickle cell patients and their specific increment during vasoocclusive crisis. Clin Immunol Immunopathol 1996; 81: 96-98. 


\section{Chapter VIII}

\section{Cytokines and soluble adhesion}

molecules in sickle cell anemia patients during hydroxyurea therapy

AW Saleh, AJ Duits, A Gerbers, C de Vries, HFP Hillen

Acta Haemarol 1998 (accepted for publication) 


\begin{abstract}
Hydroxyurea (HU) induces HbF production and can reduce painfull crises in some patients with sickle cell anemia (SS). However, HbF induction alone cannot explain the beneficial effect of HU treatment as some patients experience clinical improvement while showing only minor increases in $\mathrm{HbF}$. Other actions of $\mathrm{HU}$, in particular its effects on wascular endothelium, adhesion molecule expression and cytokine production may also play a role in the final therapeutic outcome. In order to analyse these effects we have studied the levels of interleukin-3, interleukin-6, granulocyte-macrophage colony stimulating factor, erythropoietin, stem cell factor, soluble (s) vascular adhesion molecule-1, s-intercellular adhesion molecule-1, sE-Selectin and SP-Selectin in 7 SS patients before and during five months of HU treatment. Use of HU seems to have no detectable effect on soluble adhesion molecules. Our results are in agreement with earlier data showing an increase of steady state SVCAM-1 compared to other adhesion molecules. Of the cytokines studied, only IL-3 showed an increase during therapy suggesting HU may induce early erythroid progenitors capable of producing $H$ HbF by a direct or indirect effect on IL-3 production. Remarkably, the steady state SCF levels in sickle cell patients seemed to be decreased compared to healthy controls.
\end{abstract}




\section{Introduction}

Epidemiological observations on large sickle cell populations show that patients with high HbF levels usually exhibit clinically milder disease and have a better prognosis $^{1.2}$. This forms the basis for treatment with $\mathrm{HU}$, which has been shown to induce $\mathrm{HbF}$ production ${ }^{3-6}$. As recently revealed by a multicenter trial in the United States, HU reduces the frequency of vaso-occlusive manifestations in some patients with sickle cell disease? ${ }^{3}$. Most of the beneficial effect has been attributed to the increase in $\mathrm{HbF}$ content of red blood cells resulting in less HbS polymerization. The mechanism of action by which HU induces $\mathrm{HbF}$ production is not fully elucidated. It is perhaps due to a cytotoxic action on cycling erythroblasts with preferential survival of early non-cycling erythroid progenitors with enhanced capability for $\gamma$-globin synthesis, which may undergo accelerated differentiation and maturation. However, some patients on HU therapy exhibit minor increases in $\mathrm{HbF}$ but do improve clinically, while others with higher levels of HbF do not. This suggests that other factors are involved which may be equally important ${ }^{*}$. In fact, in addition to $\mathrm{HbF}$ induction $\mathrm{HU}$ improves red blood cell hydration and deformability ${ }^{10}$. In vitro studies also show that hydroxyurea provokes significant changes in vascular endothelial cells ${ }^{11}$ and thereby may alter the adherence of blood cells to the endothelium. Vaso-active substances, adhesion molecules and cytokines are important mediators in the process of adherence and hematopoiesis ${ }^{12 \cdot 15}$. Fluctuations in the levels of these molecules may have profound influence on hematopoietic activity, the adhesion of blood cells (among them sickle cells) to vascular endothelium and eventually also clinical manifestations of disease. Recently, in vitro research showed sickle cells to be dependent on vascular cell adhesion molecule-1 (VCAM-1) for binding to endothelium ${ }^{16}$. Soluble VCAM-1 levels in sickle cell anemia (SS) patients appear to be significantly increased compared to normal controls suggesting a continuously activated endothelium state ${ }^{17.18}$. In addition, the important inflammatory cytokines (tumor necrosis factoralpha, interleukin-1 (IL-1), interleukin-6 (IL-6))] and hematopoiesis related cytokines (interleukin-3 (IL-3), granulocyte-macrophage-colony stimulating factor (GM-CSF) have all been found elevated in sickle cell patients ${ }^{14.19}$, which is most probably the result of endothelial activation as well as tissue damage by sickling and vasoocclusion in the microvasculature. Altered cytokine levels may also depend on white blood cell (WBC) activity. Low WBC counts have been associated with longer survival and fewer crises $^{20}$.

The level of bone marrow activity varies among SS patients. SS patients with a high level of bone marrow activity typically carry low levels of HbF $(<9 \%$, LFSS), have increased numbers of circulating BFU-E and elevated plasma levels of GM-CSF. Patients with low bone marrow activity have high levels of HbF (HFSS), normal numbers of circulating BFU-E and low levels of GM-CSF. In contrast, 
IL-3 tevels are increased in HFSS and low in LFSS ${ }^{14}$. These findings suggest that GM-CSF and JL-3 are involved in the regulation of SS circulating early erythroid progenitor cells and possibly play a role in the HbF induction. Furthermore, erythropoietin (EPO), IL-3, GM-CSF and stem cell factor (SCF) are all able to stimulate HbF production in cultures of erythroid progenitor cells ${ }^{21.23}$. In order to examine the contribution of cytokines and adhesion molecules to the therapeutic effect of $\mathrm{HU}$ as well as the role of cytokines in $\mathrm{HbF}$ induction we studied the levels of several cytokines and soluble adhesion molecules in SS patients before and during HU treament.

\section{Methods}

\section{Patients}

Criteria for patient selection were age between 20 and 60 years, carrier of $\beta 19$ haplotype (Benin-type), normal liver and renal function, normal folic acid, vitamin $\mathrm{B}-12$, serum iron and ferritin levels, and no transfusions in the 6 months prior to the trial or vasoocclusive crisis within 2 weeks from the start of the study. Pregnancy was ruled out before the start of the study. Seven patients, 2 males and 5 females and ranging in age from 31 to 58 years (mean 40 years) participated in the study. Each patient had four $\alpha$-globin genes $(\alpha \alpha / \alpha \alpha)$ and all patients, except for patient $D$ and $F$, carried haplotype 19 on each chromosome (19/19 or Benin/ Benin). Patient D was found to have a combination of haplotypes 19 and 3 (19/3 or Benin/Senegal) and patient $F$ was 19/20 (Benin/Bantu). None of the patients, except for patient $F$, experienced a painful crisis in the 3 months prior to the trial. Patient $F$ recovered from a severe airway infection with pain crisis 2 weeks before the start of HU. Patient B was on acenocoumarol because of a liver sequestration crisis two years prior to the trial. She developed a mild high output failure one year before the start of this study and was treated with diuretics and digoxin. Patient $G$ suffered from chronic ulcers on both legs for over 1 year prior to the HU treatment. Patients A,C,D and E did not experience any clinical symptoms or complications in the 3 months prior to the study nor did they use any medication on a regular basis other than folic acid. Each patient received a daily supplement of $5 \mathrm{mg}$ of folic acid. Compliance during the study was evaluated by pill count and by interpretation of the value of the mean corpuscular volume (MCV). The trial was conducted with the approval of the ethical board of the St. Elisabeth Hospital, Curaçao, Netherlands Antilles and all participants gave written informed consent. Ten normal HbAA individuals served as controls. 


\section{HbF, cytokines \& adhesion molecules}

HbF was quantitated by cation exchange high performance liquid chromatography $(\mathrm{HPLC})^{24}$ and cytokines by Elisa technique according to the manufacturer's guidelines (IL-6: CLB, Netherlands; IL-3, GM-CSF and soluble intercellular adhesion molecule-1 (sICAM-1): Medgenix, Belgium; sVCAM-1, sE-Selectin, sP. Selectin, Epo and SCF: R\&D, UK).

\section{Therapy}

HU was administered over a five month period in a dose ranging from 15 to 20 $\mathrm{mg} / \mathrm{kg} / \mathrm{day}$ (Table VIIl. 1). The ideal dose was determined in a study one year earlier. ${ }^{9}$. Before and during HU treatment bloodcounts were performed twice a month. HbF, IL-3, IL-6, GM-CSF, sVCAM-1, sICAM-1, sE-Selectin, sP-Selectin, SCF and Epo were determined before start of treatment and at one and five months. Patients were ambulatory and visited the policlinic twice a month at which time compliance was evaluated and symptoms and complaints were registered.

Statistical analysis was performed by Wilcoxon signed rank test.

Table VIII.1 Levels of sVCAM-1, Epo, IL-3, SCF, GM CSF and HbF in SS patients before and during HU therapy.

\begin{tabular}{|c|c|c|c|c|c|c|c|c|}
\hline $\begin{array}{c}\text { Patient } \\
(s e x-\operatorname{sen}(0)\end{array}$ & $\begin{array}{l}\text { aS-globin } \\
\text { haplotype" }\end{array}$ & $\begin{array}{l}\text { Months } \\
\text { of } \mathrm{Rx}\end{array}$ & $\underset{\%}{\mathrm{HWF}}$ & $\begin{array}{c}11 \cdot 3 \\
\mathrm{pg} / \mathrm{m}\end{array}$ & $\begin{array}{c}\mathrm{SCl} \\
\mathrm{pg} / \mathrm{mI}\end{array}$ & $\begin{array}{c}\text { Ipo } \\
\text { millimil }\end{array}$ & $\begin{array}{c}\text { SVAM-1 } \\
\mathrm{ng} / \mathrm{ml}\end{array}$ & GMNCSE \\
\hline $\begin{array}{l}A_{1} \\
(M-58)\end{array}$ & $19 / 19$ & $\begin{array}{l}0 \\
1 \\
5\end{array}$ & $\begin{array}{r}6.2 \\
- \\
26.3\end{array}$ & $\begin{array}{r}7.3 \\
13.3 \\
11.2\end{array}$ & $\begin{array}{l}559 \\
78.5 \\
84.1\end{array}$ & $\begin{array}{r}403 \\
6674 \\
600\end{array}$ & $\begin{array}{l}1.910 \\
2.273 \\
1.890\end{array}$ & $\begin{array}{r}138 \\
100\end{array}$ \\
\hline $\begin{array}{l}B \\
(F-33)\end{array}$ & $19 / 19$ & $\begin{array}{l}0 \\
1 \\
5\end{array}$ & $\begin{array}{r}2.5 \\
4.3 \\
17.1\end{array}$ & $\begin{array}{l}22.4 \\
16.1 \\
19.5\end{array}$ & $\begin{array}{l}565 \\
363 \\
446\end{array}$ & $\begin{array}{l}85 \\
43 \\
88\end{array}$ & $\begin{array}{l}1.204 \\
1.306 \\
1.320\end{array}$ & $\begin{array}{r}10.6 \\
8.1\end{array}$ \\
\hline C & 19119 & $\begin{array}{l}0 \\
1 \\
5\end{array}$ & $\begin{array}{r}11.4 \\
14.5\end{array}$ & $\begin{array}{r}22.4 \\
44.3\end{array}$ & $\begin{array}{l}527 \\
536 \\
520\end{array}$ & $\begin{array}{r}68 \\
49 \\
128\end{array}$ & $\begin{array}{r}924 \\
1.059 \\
870\end{array}$ & 8 \\
\hline D & $19 / 3$ & $\begin{array}{l}0 \\
1 \\
5\end{array}$ & $\begin{array}{l}12.9 \\
17.1 \\
29.5\end{array}$ & $\begin{array}{r}9.2 \\
16.3 \\
320\end{array}$ & $\begin{array}{l}702 \\
757 \\
737\end{array}$ & $\begin{array}{l}54 \\
59 \\
57\end{array}$ & $\begin{array}{l}2.420 \\
2.295 \\
1.735\end{array}$ & $\begin{array}{r}R .7 \\
7.4 .4\end{array}$ \\
\hline $\begin{array}{l}\mathrm{E} \\
(\mathrm{F}-\mathrm{i}-\mathrm{A})\end{array}$ & $19 / 19$ & $\begin{array}{l}0 \\
1 \\
5\end{array}$ & $\begin{array}{r}7.8 \\
13.5 \\
10.4\end{array}$ & $\begin{array}{r}4.3 \\
11.5 \\
19.9\end{array}$ & $\begin{array}{l}649 \\
435 \\
625\end{array}$ & $\begin{array}{r}113 \\
89 \\
144\end{array}$ & $\begin{array}{r}170 \\
717 \\
963\end{array}$ & $\begin{array}{r}B .1 \\
14.6\end{array}$ \\
\hline $\begin{array}{l}F \\
(M(-35)\end{array}$ & $19 / 19$ & $\begin{array}{l}0 \\
1 \\
5\end{array}$ & $\begin{array}{l}1.4 \\
2.2 \\
1.5\end{array}$ & $\begin{array}{l}4.0 \\
3.8 \\
7.6\end{array}$ & $\begin{array}{l}545 \\
480 \\
320\end{array}$ & $\begin{array}{l}84 \\
32 \\
83\end{array}$ & $\begin{array}{l}4.086 \\
2.001 \\
1.725\end{array}$ & $\begin{array}{r}7.1 \\
5.6\end{array}$ \\
\hline $\begin{array}{l}\mathrm{G} \\
(\mathrm{F}-3 i)\end{array}$ & $14 / 19$ & $\begin{array}{l}0 \\
1 \\
5\end{array}$ & $\begin{array}{r}4.3 \\
10.9 \\
25.2\end{array}$ & $\begin{array}{l}12.5 \\
24.3 \\
21.3\end{array}$ & $\begin{array}{l}1.055 \\
1.066 \\
1.059\end{array}$ & $\begin{array}{r}141 \\
138 \\
43 \\
\end{array}$ & $\begin{array}{l}3.114 \\
2.164 \\
2.195\end{array}$ & $\begin{array}{r}130 \\
100\end{array}$ \\
\hline Controls" & & & . & $30.2 \pm 16$ & $1.133+303$ & 10149 & $596-177$ & 0 \\
\hline
\end{tabular}

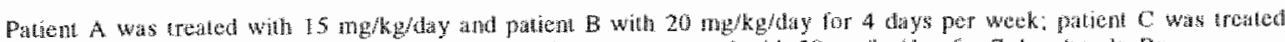

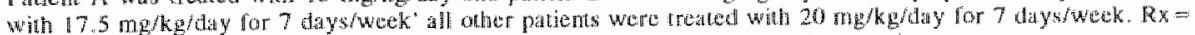

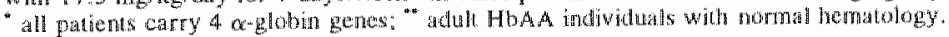




\section{Results}

Like in previous studies, $\mathrm{HbF}$ increased in the majority of patients who took $\mathrm{HU}$ (Tables VIII.1 and VIII.2). The HbF level increased 2 to 5 fold in all patients except in patient $\mathrm{C}$ and $\mathrm{F}$ (Figure VIII.1). Patient $\mathrm{C}$ showed a minor increase in HbF. Patient $F$ only had a short-lived increment in his HbF which was explained by proper compliance during the first 2 months of treatment (as confirmed by increase of $\mathrm{MCV}$ from 79 to $87 \mathrm{fl}$ and correct pill count) but failing compliance thereafter. A significant decrease in reticulocyte counts was observed suggesting a reduction in the rate of hemolysis (Table VIII.2). WBC counts showed a slight but not significant decrease. No bone marrow toxicity was observed. Except for patient $G$, who showed healing of one leg ulcer, no significant changes were observed in the clinical condition of the patients during HU treatment.

Table VIIl.2 Mean laboratory values before starting HU (imitial) and after 5 months of treatment with $H U$ (find).

\begin{tabular}{|c|c|c|c|}
\hline & Initial value & Final value & $\mathrm{p}$ value \\
\hline Total $\mathrm{Hb}, \mathrm{g} / \mathrm{dl}$ & $7.1 \pm 1.5$ & $8.1 \pm 1.0$ & n.s. \\
\hline Leukocytes, x $10 \% / \mu 1$ & $10.8 \pm 2$. & $9.0 \pm 1.7$ & n.s. \\
\hline Lymphocytes $\times 10^{3} / \mu 1$ & $3.4 \pm 1.0$ & $3.2 \pm 0.7$ & $n . s$ \\
\hline $\mathrm{MCV}, \mathrm{fl}$ & $94 \mathbb{1 1} 11$ & $115 \pm 17$ & $<0.05$ \\
\hline Absolute reticulocyles, $x \quad 10^{3} / \mu 1$ & $259 \pm 95$ & $98 \pm 60$ & $<0.05$ \\
\hline $\mathrm{HbF}, \%$ & $6.6 \pm 4.3$ & $17.8 \pm 10.0$ & $<0.05$ \\
\hline Epo, mlu/m! & $140 \pm 118$ & $164 \pm 198$ & n.s. \\
\hline $\mathrm{SCF}, \mathrm{pg} / \mathrm{ml}$ & $657 \pm 186$ & $650 \pm 251$ & ns. \\
\hline$|\mathrm{L}-3, \mathrm{pg} / \mathrm{m}|$ & $11.7 \pm 7.8$ & $22.3 \pm 12.5$ & 0.08 \\
\hline GM-CSF, pg/ml & $17.8 \pm 21.8$ & $8.1 \pm 1.4$ & n.s. \\
\hline $\mid \mathrm{L}-6_{n} \mathrm{pg} / \mathrm{ml}$ & $7.4 \pm 16.4$ & $2.2 \pm 3.5$ & m.s. \\
\hline SICAM-L, $\mathrm{ng} / \mathrm{ml}$ & $127 \pm 95$ & $177 \pm 104$ & n.s. \\
\hline SVCAM $-1, \mathrm{ng} / \mathrm{ml}$ & $2.247 \pm 1.264$ & $1.530 \pm 493$ & n.s. \\
\hline
\end{tabular}

Values represent man $\pm S D$, p value of $<0.05$ considered to be significant; n.s. = non significitnt

Compared to $S V C A M-1$ levels in a normal population, baseline levels of s-VCAM were all enhanced $(p<0.05$, Table VIII.1). However, the baseline sVCAM -1 in patient $G$ should be interpreted with caution since he experienced an infection and crisis only a few weeks prior to the start of this study. During the HU treatment the mean S-VCAM level showed no consistent pattern of change. The sP-Selectin, SE-Selectin and SICAM levels of the patients were comparable to healthy controls and were not influenced by HU treatment (data not shown).

As expected the SS patients revealed increased EPO levels $(p<0.01)$. However, SCF levels were lower in the SS patients compared to healthy controls $(p=0.001$, Table VIII.1. Figure VIII.2). There existed no correlation between HbF and 
baseline levels of EPO or SCF (Table VIII. 1); both levels remained unchanged during the HU treatment.

Steady state levels of IL-3 were comparable to healthy controls. No correlation was observed between baseline HbF and IL-3 or GM-CSF levels. After the start of the HU therapy all patients, except patient B, showed an increase in IL-3 (Table VIII. I and Figure VIII.1). The mean IL-3 level increased but did not reach statistical significance (Table VIII.2).

GM-CSF (Table VIII.1) and II-6 levels (data not shown) varied considerably but appeared elevated in some patients compared with healthy controls. No specific correlation with any other parameter was observed. The levels did not change during HU therapy (Table VIII.2).
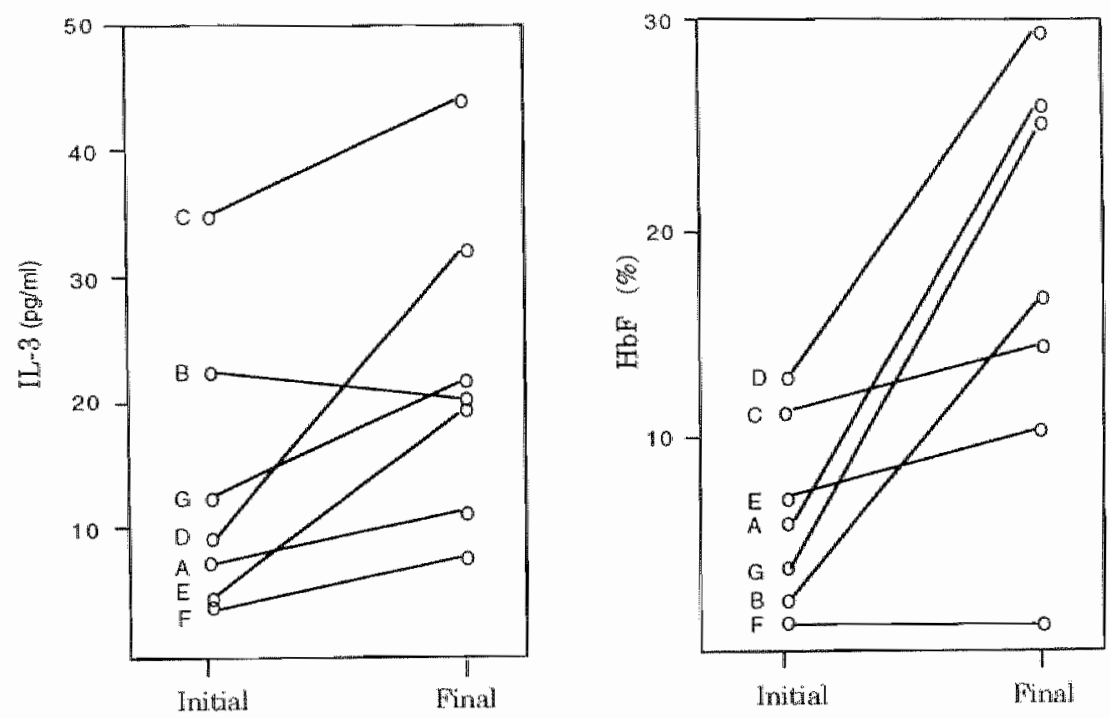

Figure VIII.I Response of $L \mathrm{~L}-3$ and HbF to HU treatment in SS patients.

\section{Discussion}

Although HU therapy induces HbF production, this effect has not proven to be the only explanation for the beneficial effect of HU in SS patients. Recent studies have established that cytokines and adhesion molecules play a central role in the interaction between endothelium and blood cells. In order to examine the contribution of cytokines and adhesion molecules to the therapeutic effect of HU as well as the role of cytokines in $\mathrm{HbF}$ induction we studied the levels of several cytokines and soluble adhesion molecules in SS patients before and during $\mathrm{HU}$ treament. 


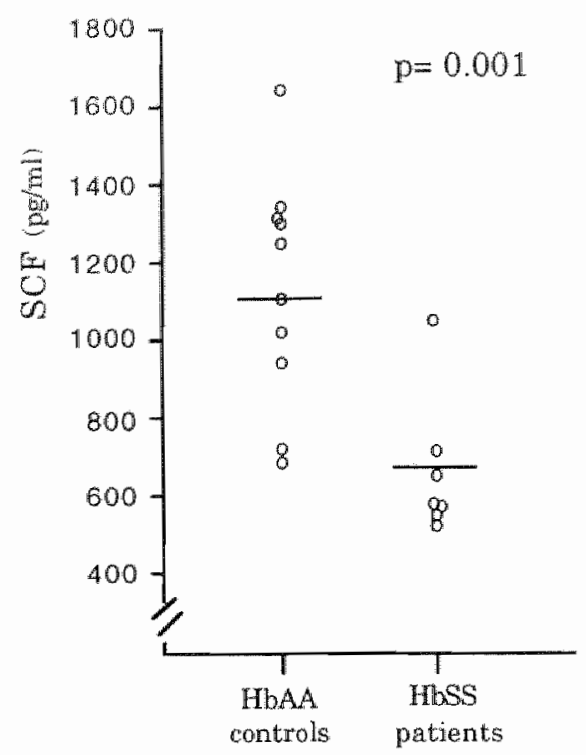

Figure VIII.2 Plasma steady state levels of SCF in SS patients compared to normal controls.

No effects of HU on soluble adhesion molecules, sVCAM-1, sICAM-1, sP-Selectin and SE-Selectin, were observed. The finding of increased SVCAM -1, levels before treatment, compared to other adhesion molecules, is in support of previous studies ${ }^{17.18 .25}$ and might be due to the effects of VCAM-1 specific cytokines like IL$13^{26}$. Furthermore, viral infections known for their ability to trigger vaso-occlusive episodes, can induce VCAM-1 expression on endothelial cells ${ }^{27}$. SVCAM-1 as well as IL-6 levels have also been shown to increase significantly in the event of a vasoocclusive crisis ${ }^{17.2 B}$. It could be postulated that the increase in SVCAM-1 reflects a continuously activated endothelium state which renders patients more sensitive to crisis - triggering factors. Therefore it could be expected that if $\mathrm{HU}$ would have beneficial effects on the endothelium activity state, this should be reflected as lowered sVCAM-I levels. However, sVCAM-1 levels showed no consistent change. Still, what should be considered is the fact that SVCAM-1 may fluctuate strongly depending on the clinical condition of the patient. In our study patient $G$ had two legulcers and patient $F$ had experienced a pain crisis and airway-infection two weeks prior to the start of the HU therapy. Patient B was on a coumarine derivative which has been shown to inhibit VCAM-I expression ${ }^{25.29}$. Obviously, these factors may complicate the interpretation of sVCAM-1 levels in a small group of participants such as ours.

Of the cytokines analysed only IL-3 seemed to be enhanced by HU therapy, with the exception of 1 patient. However, this patient was taking several drugs which could have interfered with IL-3 determination or biochemical activity. From studies 
in witro and in primates it is known that IL-3 can induce formation of early erythroid progenitors and $F$ reticulocytes ${ }^{19.21}$ and may be produced by various celtypes, including bone marrow stromal cells ${ }^{30}$. The increase of $1 \mathrm{~L}-3$ observed in mosi patients after start of HU therapy is perhaps explained by induction of bone marrow stromal cells in response to the cytotoxic action of hydroxyurea on hematopoietic cells. Alternatively, a direct effect of hydroxyurea on bone marrow stromal cells or blood cells leading to production of IL-3 cannot be excluded. Nevertheless, the increment of IL-3 after the start of HU therapy may be responsible for the increase of $\mathrm{HbF}$ by stimulating proliferation of erythroid progenitors that carry enhanced capability for HbF synthesis. This is also supported by the correlation between steady state HbF and IL-3 reported by Croizat ${ }^{19}$. The correlation between steady state $\mathrm{HbF}$ and $\mathrm{IL}-3$ could not be confirmed by us possibly due to the small sample size and discrepancies between studies in the phenotypical background of SS patients.

In addition to IL-3, SCF is also active during early hematopoiesis. We show for the first time a lowered steady state SCF level in SS patients compared to normal controls. Epo levels in SS patients have been reported to be increased, but relatively low for the degree of anemia ${ }^{31}$. It has been shown that SS-circulating progenitors express an increased sensitivity to Epo, which is the result of the interaction between these cells and their enviromment ${ }^{32}$. Increased activity of other factors, in particular cytokines which induce proliferation and differentiation of early erythroid progenitors in stress situations, has been postulated to explain the relatively low Epo levels in SS patients. Perhaps, a similar mechanism could also be of influence on circulating SCF levels.

In conclusion, we have found no evidence of a significant effect of HU at the level of vascular endothelium. However, as soluble adhesion molecules tend to thuctuate depending on external factors and the clinical condition of the patient, proper interpretation of $\mathrm{HU}$ effects on adhesion molecules will probably require a longer duration of study and a larger group of patients. Cytokine analysis showed a tendency of IL-3 levels to increase during HU therapy, suggesting IL-3 to be involved in the induction of erythroid progenitors capable of producing HbF. Also, a specific decrease of steady state SCF levels was shown. Future studies should further clarify the role and use of these cytokines in the treatment of SS patients. 


\section{References}

1. Adekile AD. Huisman THJ. Hb F in sickle cell anemia. Experientia 1993; 49: $16-27$.

2. Plat OS, Thorington BD, Brambilla DJ. Pain in sickle cell disease: Rates and risk factors. N Engl I Med 1991; 325: 11-16.

3. Charache $S$. Dover $G$, Moyer M, Moore J. Hydroxyurea - induced augmentation of fetal hemoglobin production in patients with sickle cell anemia. Blood 1987; 69: 109-116.

4. Sumoza A, Bissotti RS. Treatment of sickle cell anemia with hydroxyurea: results in twenty-six patients. Blood 1986; 68:67a.

5. Platt 0 , Orkin S, Dover $\mathrm{G}$, Beardsley P, Miller B. Hydroxyurea enhances fetal hemoglobin production in sickle cell anemia. I Clin Invest 1987; 74:652 - 656.

6. Rodgers GP, Dover GJ, Noguchi CT: Schechter AN, Nienhuis AW. Hematologic responses of patients with sickle cell disease to treatment with hydroxyurea. $N$ Engl J Med 1990; 322: 1037-1045.

7. Charache S, Terrin ML, Moore RD, Dover GJ, Barton DB, Eckert SV, McMahon RP, Bonds DR, and the Investigators of the Multicenter Study of Hydroxyurea in Sickle Cell Anemia. Effect of Hydroxyurea on frequency of painful crises in Sickle Cell Anemia. N Engl J Med 1995; 332: 1317-1322.

8. Vichinsky EP, Lubin BH. A cautionary note regarding hydroxyurea in sickle cell diseases. Blood 1994; 83: $366-372$.

9. Saleh AW, Velvis HJR, L-H.Gu, Hillen HFP, Huisman THJ. Hydroxyurea therapy in sickle cell anemia patients in Curacao, The Netherlands Antilles. Acta Haematol. 1997; 98: 125-129.

10. Ballas SK, Dover GJ, Charache S. Effect of hydroxyurea on the rheological properties of sickle erythrocytes in vivo. Am J Hematol 1989; 32: 104-111.

11. Adragna NC, Fonseca P. Lauf PK. Hydroxyurea affects cell morphology, cation transport, and red blood cell adhesion in cultured vascular endothelial cells. Blood $1994: 82: 553-560$.

2. Pieters RC, Rojer RA, Saleh AW, Saleh AEC, Duits AJ. Molgramostim to treat SS-sickle cell leg ulcers. The Lancet 1995; 345, no 8948: p 528.

13. Saleh AW, Pieters RC, Duits AJ. rhGm-CSF (Molgramostim): A potent inducer of sickle cell wasomocclusive crisis. Abstract for the 20th Annual Meeting. National Sickle Cell-Disease Program, March 1995, Philadelphia, USA

14. Francis RB. Haywood LJ. Elevated immunoreactive tumor necrosis factor and interleukin. I in sickle cell disease. INatl Med Assoc 1992; 84:611-615.

15. Francis RB ir. Elevated fibrin D-dimer fragmen in sickle cell anemia: evidence for the activation of congulation during steady state as well as in painfull crisis. Haenostas is 1989; 19:105-111.

16. Swerlick RA. Eckman JR, Kumar A. Jeinler M, Wick TM. $\alpha 4$ Bl-Integrin expression on sickle rericulocytes: vascular cell adhesion molecule -1 dependent binding to endothelium. Blood 1993; 82: 1891.99. 
17. Duits AJ, Pieters RC, Saleh AW, Rosmalen van E, and Rojer RA. Enhanced levels of soluble VCAM-1 in sickle cell patients and their specific increment during vasoacclusive crisis. Clin Immunol Immunopathol 1996; 81: 96-98.

18. Solovey A, Yi Lin BS, Browne P. Choong S, Wayner E, Hebbel RP. Circullating activated endothelial cells in sickle cell anema. $N$ Engl I Med 1997; 337: 1584 1590

19. Croizat H. Circulating cytokines in sickle cell patients during steady state. Brit J Haematol 1994; 87: 592-597.

20. Platt OS, Brambilla DJ, Rosse WF, Minner PF, Castro O, Steinberg MH, Klug PP. Mortality in sickle cell disease: Life expectancy and risk factors for early death. $N$ Engl J Med 1994; 330: 1639-1644.

21. Umemura $T$, al-Khatti A, Donahue RE, Papayannopoulou T, Stamatoyannopoulos G. Effects of interleukin-3 and erythropoietin on in vivo erythopoiesis and F-cel formation in primates. Blood 1989; 74: $1571-1576$.

22. Migliaccio AR, Migliaccio G, Brice M, Constantoulak is P, Stamatoyannopoulos G, Papayannopoulou $T$. Influence of recombinant hematopoietins and of fetal bovine serum on the globin synthetic pattern of human BFU-E. Blood 1990; 76: 1150 1157 .

23. Miller BA, Perrine SP, Bernstein A, Lyman SD, Willians DE, Bell LL, Olivieri NF. Inthence of Steel Factor on hemoglobin synthesis in sickle cell disease. Blood 1992; 79:186i-1868.

24. Bissé $\mathrm{E}$, Wieland $\mathrm{H}$. High performance liquid chromatographic separation of human haemoglobins: Simultaneous quantitation of foetal and glycated haemoglobins. I Chromatogr 1988;434: 95-110.

25. Joneckis CC, Ackley RL, Orringer EP, Wayner EA, Parise LV. Integrin alpha 4 beta 1 and glycoprotein IV (CD36) are expressed on circulating reticulacytes in sickle cell anemia. Blood 1993; 82: 3548-3555.

26. Bochner BS, Klunk DA, Sterbinski SA, Coffman RI, Schleimer RP. IL-13 selectively induces vascular adhesion molecule-1 expression in human endothelial cells. J Immunol 1995; 154: 799-803.

27. Smolinski PA, Offerman MK. Eckman IR. Wick TM. Double-stranded RNA induces sickle cell adherence to endothelium: A potential role for viral intecion in vaso-occlusive pain episodes in sickle cell anemia. Blood 1995; 85; 2945-2950.

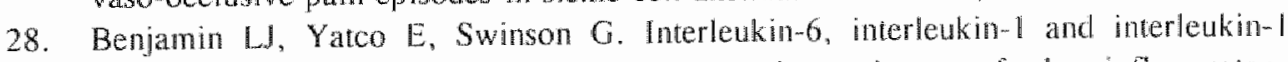
receptor antagonist (L-1RA), mediators and regulators of the inflammatory response are altered during acute painful vaso-occlusive crisis. Abstract for the National Sickle Cell Disease Program and American Pain Symposinum, Philadelphia, 1993.

29. Chen CC, Rosenbloom CL. Anderson DC, Manning AM. Selective inhibition of ESelectin, wascular cell adhesion molecule-1, and intercellular adhesion molecule-1 expression by inhibitors of $1 \kappa$ B- $\alpha$ phosphorylation. J Immunol $1995 ; 155$ : 3538 3545 . 
30. Gibson FM, Scopes J, Daly S, Ball S, Gordonsmith EC. Haematopoietic growth factor production by normal and aplastic anaemia stroma in long term bone marrow culture. Brit J Haematol 1995; 91: 551-561.

31. Sherwood J, Goldwasser $E$, Chilcote $R$, Carmichael $\mathbb{L D}$, Nagel RL. Sickle cell anemia patients have low erythropoietin levels for their degree of anemia. Blood 1986; $67: 44 \sim 49$.

32. Croizat H, Nagel RL. Circulating BFU-E in sickle cell anemia: Relationship to percent fetal hemoglobin and BPAwike activity. Exp Hematol 1988; 16: 946-949. 


\section{Chapter IX}

\section{Levels of endothelial, neutrophil}

and platelet specific

factors in sickle cell anemia patients during hydroxyurea therapy

AW Saleh, HFP Hillen, AJ Duits 


\section{Abstract}

It has been shown that the clinical course of sickle cell (SS) patients can be ameliorated by administration of hydroxyurea ( $\mathrm{HU}$ ). Induction of $\mathrm{HbF}$ is thought to be the mechanism responsible for clinical improvement in some patients. However, HU has a variable effect on $\mathrm{HbF}$ production and there exists no good correlation between the extend of $\mathrm{HbF}$ increase and clinical response. On the other hand the degree of adherence of sickle cells to vascular endothelium and neutrophil counts correlate well with clinical severity. Being a cytotoxic drug. used in myeloproliferative diseases, HU may alter proliferation among various cell lines. Moreover, HU has been reported to reduce RBC adhesion receptor expression in young SS individuals and induces changes in endothelial cells in vitro. It should be conceived that, in addition to its effects on $\mathrm{HbF}$ production, HU may change the clinical symptoms of SS patients by affecting the degree of adherence of different blood cells, by influencing the activity of endothelium as well as the activity of WBC and platelets. To analyze whether several of the determinants of adhesion are modulated by HU treatment we studied the levels of endothelial activity [soluble vascular adhesion molecule-1(sVCAM-1), LL-8, fibronectin], neutrophil activity [sL-Selectin, sLL-6 receptor- $\alpha$, myeloperoxidase] and platelet activity Ivon Willebrand Factor in relation to clinical symptoms, hematological data and HbF levels in 8 SS patients before and during 5 months of HU therapy. Steady state SVCAM-1 levels are increased compared to normal controls and a significant decrease is noted during $\mathrm{HU}$ treatment, suggesting a decrease in the interactions between RBC and vascular endothelium. The IL-8 levels are comparable to those in normal controls and remain unaffected by HU therapy. Intercurrent infection and crises reveal striking increases in IL-8 which are accompanied by leucocytosis, but otherwise the IL-8 levels do not correlate with hematological data. HU has no demonstrable effect on fibronectin or soluble neutrophil adhesion molecules, but the levels of myeloperoxidase decrease significantly while WBC counts do not, implying a reduction in neutrophil activity which may help attenuate the propagation phase of a vasoocclusive crisis. 


\section{Introduction}

Hydroxyurea (HU) has been used in sickle cell (SS) anemia with the purpose of inducing $\mathrm{HbF}$ production and improving the clinical condition of patients. Following treatment with $\mathrm{HU}$, SS patients are known to exhibit different levels of HbF increase and some patients show clinical improvement measured as a reduction in the frequency of painful crises. However, clinical amelioration does not always parallel HbF increment. Some SS patients with considerable HbF increase have been reported to fare worse and others, with very litule HbF increase, experience clinical improvement ${ }^{2,3}$. This discrepancy suggests that factors other than the HbF level may be important to the clinical outcome in response to $\mathrm{HU}$. The factor that is responsible for much of the pathophysiology of sickle cell anemia is adhesion of blood cells resulting in microvascular acclusion. The aclhesion of young deformable sickle cells to endothelium, trough receptors such as integrin VLA 4 and CD36 on red blood cells and vascular adhesion molecule-1 (VCAM-1) on endothelial cells, has been shown to play an important role in the initiation of the vaso-occlusive crisis ${ }^{4-6}$. Furthermore, effects of polymorphonuclear leukocytes and several plasma factors, among which cytokines, procoagulant and vaso-active substances also influence the adhesive processes ${ }^{7 \cdot 10}$. White blood cell (WBC) counts are often increased in sickle cell patients and WBC counts of more than 15,000 cells $/ \mathrm{ml}$ are in fact associated with an increased risk of early death" ${ }^{11}$. Plasma proteins that have been implicated in promoting the adhesion between sickle cells, WBC (predominantly neutrophils) and endothelium include fibronectin, fibrinogen, von Willebrand factor and thrombospondin ${ }^{12 \cdot 15}$. Several cytokines can induce multiple activation states of the endohelium and activate leucocytes ${ }^{5,16,17}$. Interleukin-8, in particular when present in high concentration, may also directly activate the adhesion specific integrin VLA-4 on sickle cells ${ }^{17}$. On the other band, red cell absorption of $1 \mathrm{~L}-8$, with trapping in the RES system, may be a mechanism of limiting a systemic inflammatory process ${ }^{1 k}$. Among all these determinants of adhesion, the vascular endothelium itself, is also considered to be an important factor in the initiation of the vaso-occlusion ${ }^{19.219}$. In addition to HbF induction, HU treatment has already been shown to be responsible for changes such as macrocytosis, improved red blood cell (RBC) deformabillity and hydration status ${ }^{42}$. Moreover, a recent study has shown decrease of VLA-4 and CD36 on reticulocytes in pediatric SS patients treated with $\mathrm{HU}^{22}$. Still, in view of the multilactorial etiology of sickle cell vaso-occlusion many other actions of HU in sickle patients, should be considered. Here we report the effects of hydroxyurea on endothelial and neutrophil activity as well as on I1-8 and von Willebrand factor ( $r W F$ ) in relation to the clinical symptoms, hematological data and HbF levels in SS patients. 


\section{Materials and methods}

\section{Patients}

Criteria for patient selection were age between 18 and 65 years, carrier of $\beta$ haplotype 19 (Benin type) and four $\alpha$-globin genes, normal liver and kidney function and normal iron levels. Eight patients, four males and four females and ranging in age from 18 to 60 years (mean 39 yrs), participated in the study. Six paticnts carried haplotype 19 on each chromosome (19/19 or Benin/Benin). One patient (patient D) had a combination of haplotype \#19 and $\$ 3$ (Benin/Senegal) and the other (patient F) had haplotype $19 / 20$ (Benin/Bantu). None of the patients had received a transfusion within six months prior to the start of the study, nor had they experienced a painful crisis in the six months prior to the trial. Patient $B$ was on acenocoumarol because of a liver sequestration crisis four years prior to the trial. She recently complained about pain in her left knee which was believed to be a consequence of sickle cell complications at the level of the cartilage. Patient D started to experience backaches one year prior to the study at a frequency of approximately once a month. This symptom was diagnosed as osteoarthrosis of the spine rather than a direct sickle cell related complication. She used acetaminophen as analgesic. Patients $\mathrm{A}, \mathrm{C}, \mathrm{E}, \mathrm{F}, \mathrm{G}$ and $\mathrm{H}$ did not experience any clinical symptoms or complications in the six months prior to the study nor did they use any medication on a regular basis other than folic acid. Each patient received a daily supplement of $5 \mathrm{mg}$ of folic acid. Compliance during the study was evaluated by pill count and by interpretation of the value of the mean corpuscular volume (MCV), Clinical parameters to be monitored during the study included episodes of painful crises or any other objective vaso-occlusive event. Painful crises were defined as pain in extremities, chest or back not relieved by acetaminophen or requiring admittance to the hospital. The trial was conducted with the approval of the Ethical Board of the St. Elisabeth Hospital, Curaçao, Netherlands Antilles and all participants gave written informed consent. Ten normal HbAA individuals served as controls.

\section{Therapy}

HU was administered over a five month period. Patients received a dose of 1000 $\mathrm{mg} / \mathrm{day}$ or $1500 \mathrm{mg} / \mathrm{day}$ depending on their bodyweight (Table IX. I).

\section{Sampling}

To establish baseline values, blood counts, HbF, IL-8, sVCAM- sIL-6 and sLSelectin were detemined at 3 different times during a three week period prior to the start of HU therapy. During HU treatment bloodsamples were taken once a month. 


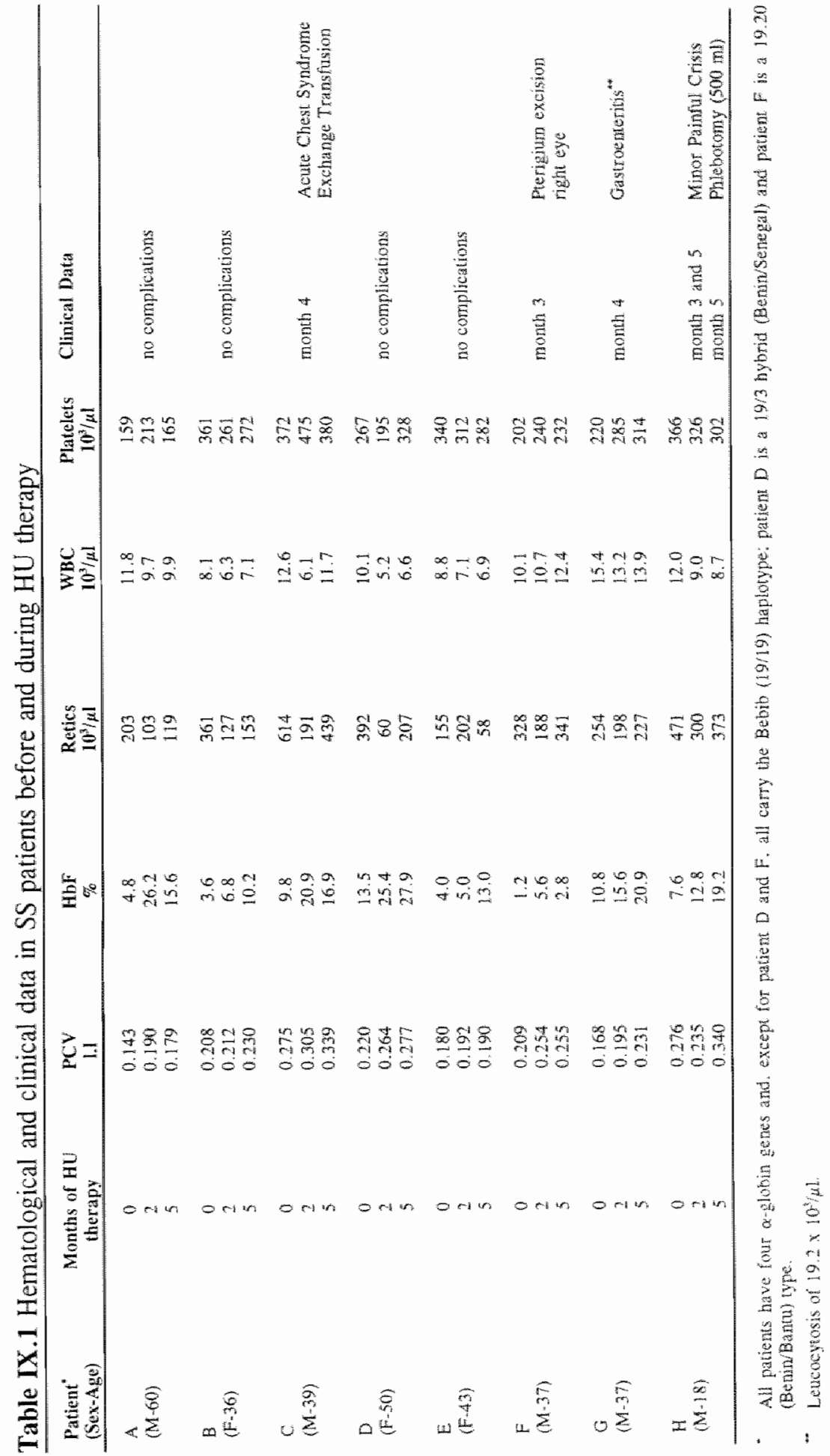




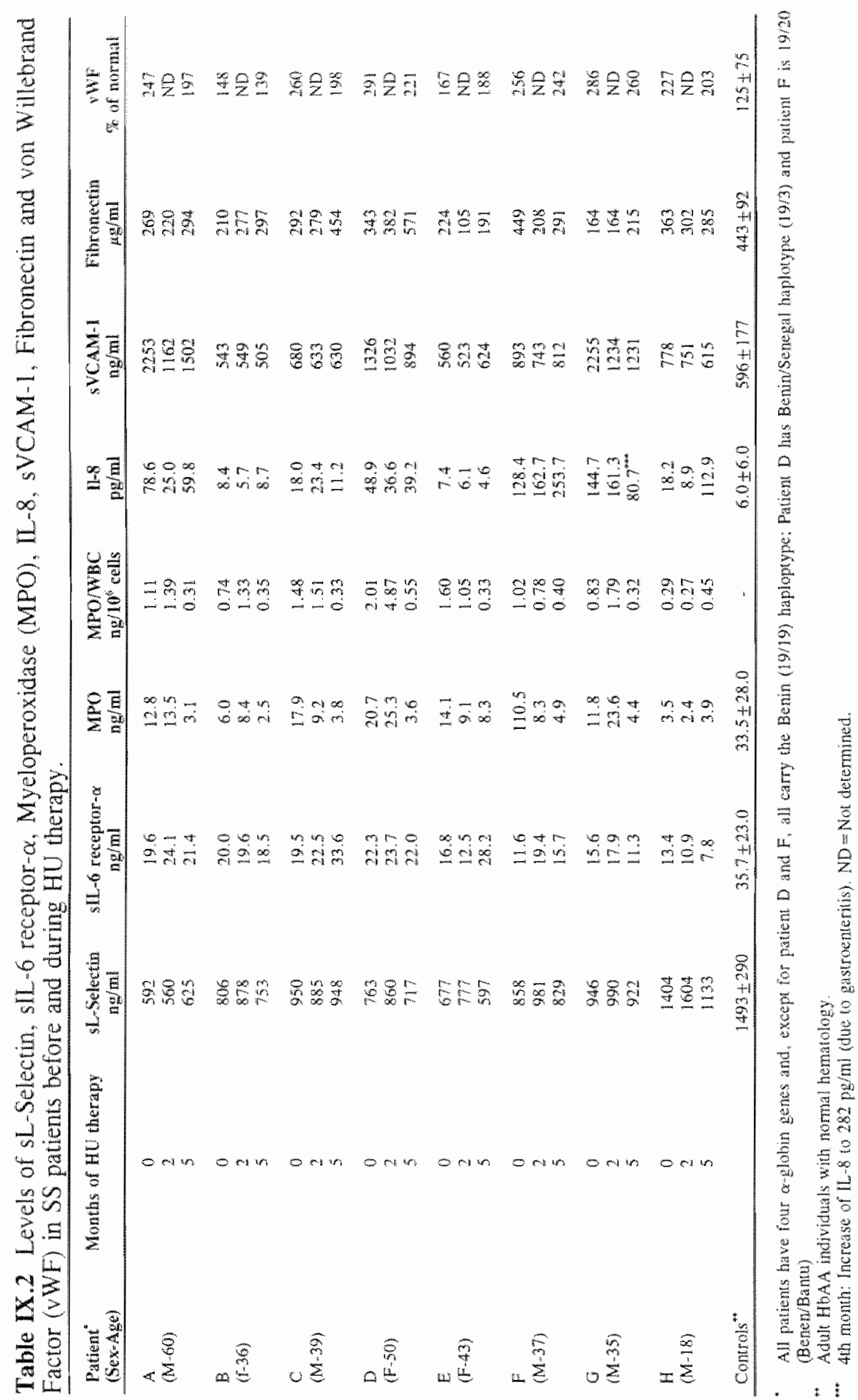


Patients were ambulatory and visited the policlinic twice a month at which time compliance was evaluated and symptoms and complaints were registered. HbF, myeloperoxidase (MPO), cellular fibronectin (FN), II-8, soluble adhesion molecules \& $\mathrm{vWF}$.

$\mathrm{HbF}$ was quantitated by cation exchange high performance liquid chromatography (HPLC) $^{23}$. The level of neutrophil activity was assessed by determining neutrophilspecific soluble adhesion molecules, sL-Selectin (CD62L) and the slL-6 receptor (CD64 or FcgRI) as well as plasma myeloperoxidase which is released from neutrophils. Endothelial activity was determined by measuring levels of s-VCAM, FN and IL-8. Soluble adhesion molecules, cytokines, cellular FN and MPO levels were detected by Elisa technique according to the manufacturer's guidelines [IL-8: CLB, Netherlands; sVCAM-1, sIl-6, sL-Selectin, MPO and FN: R\&D, England]. Von Willebrand factor was determined by adding STA LIA VWF reagent to plasma samples. The reagent consists of latex particles coated with VWF-specific polyclonal antibodies that agglutinate in the presence of vWF. Agglutination results in increase of the optical density, which is directly proportional to the $V W F$ concentration, and can be measured using a STA analyzer (Boehringer Mannheim Diagnostica, Germany).

\section{Statistical analysis}

Data were analysed by the Wilcoxon signed rank test. A p value of $<0.05$ was considered significant.

\section{Results}

\section{Hematologic and clinical responses (Tables IX.1 and IX.3)}

In most patients the hematological profile improved and hemolytic rate decreased in response to $\mathrm{HU}$. HbF levels increased in all patients but showed a considerable interindividual variability. In order to avoid viscosity related vaso-occlusive complications due to increasing packed cell volumes ( $\mathrm{PCV}$ ), the protocol of the study recommended a phlebotomy at PCV values between 30 and $351 / 1$ or higher. Patient $\mathrm{C}$ developed a high PCV and unfortunately experienced a severe acute chest syndrome in the 3 th month of HU therapy before phlebotomy. He recovered after an exchange transfusion was performed. Patient $\mathrm{H}$ developed a rellatively high $\mathrm{PCV}$ in the 5 th month of HU treatment but this was reduced by a phlebotomy of $500 \mathrm{ml}$. This patient also experienced two minor episodes of painful crises, one during the third month, and one in the 5th month of HU therapy. These crises were managed at home with analgesics. Patient A showed a decrease of his hemoglobin level by the 2 th month which could have been caused by a cytotoxic effect of HU. The HU 
therapy was interrupted for one week and restarted at $10 \mathrm{mg} / \mathrm{kg} /$ day (instead of the ustal $55 \mathrm{mg} / \mathrm{kg} /$ day). Consequently his $\mathrm{HbF}$ level also decreased to some extend. The knee complaints of patient $B$ improved subjectively. The complaints of backache of patient $\mathrm{D}$ remained unchanged during the study. Patient $\mathrm{F}$ underwent a minor surgical procedure on his eye at the start of the 3th month of HU therapy. He showed less proper compliance around this time which resulted in a decrease of hus $\mathrm{HbF}$ level. Patient E experienced a infectious gastroenteritis at the beginning of the 4 th month and accordingly revealed a leucocytosis.

Table IX.3 Mean laboratory values before starting HU (initiall and after 5 months of treatment with HU (tinal).

\begin{tabular}{|c|c|c|c|}
\hline & Initial value & Final value & p value \\
\hline Total $\mathrm{Hb}, \mathrm{g} / \mathrm{dl}$ & $7.3 \pm 1.6$ & $8.7 \pm 1.9$ & n.s. \\
\hline$W B C \times 10^{3} / \mu 1$ & $11.5 \pm 2.5$ & $10.1 \pm 3.7$ & n.s. \\
\hline Platelets $\times 10^{3} / \mu 1$ & $281 \pm 100$ & $287 \pm 103$ & n.s. \\
\hline$M V C, n$ & $95 \pm 9$ & $111 \pm 14$ & $<0.05$ \\
\hline Absolute retics $\times 10^{3 / \mu t}$ & $365 \pm 154$ & $220 \pm 220$ & n.s. \\
\hline $\mathrm{HbF}, \%$ & $7.2 \pm 4.1$ & $15.2 \pm 7.8$ & $<0.05$ \\
\hline $\mathrm{LDH}, \mathrm{U} \|$ & $1486 \pm 522$ & $1080 \pm 407$ & $<0.05$ \\
\hline $\mathrm{s} L \mathrm{~L}-6$ receptor $-\alpha, \mathrm{pg} / \mathrm{ml}$ & $17.9 \pm 6.2$ & $19.1 \pm 7.2$ & n.s. \\
\hline sL-Selectira, ng $/ \mathrm{ml}$ & $892 \pm 239$ & $809 \pm 282$ & n.s. \\
\hline MPO*, ngg/ml & $12.0 \pm 9.0$ & $4.3 \pm 1.7$ & $<0.05$ \\
\hline MPO/WBC, ng $/ 10^{\circ}$ cells & $1.1 \pm 0.8$ & $0.5 \pm 0.4$ & $<0.05$ \\
\hline s-VCAM-1, $\mathrm{ng} / \mathrm{ml}$ & $1216 \pm 860$ & $811 \pm 293$ & $<0.05$ \\
\hline Fibronetic, $16 \mathrm{~g} / \mathrm{ml}$ & $289 \pm 135$ & $322 \pm 99$ & n.s. \\
\hline $11-8, \mathrm{pg} / \mathrm{ml}$ & $61 \pm 93$ & $79 \pm 104$ & n.s. \\
\hline vWF*, we of normal & $235 \pm 52$ & $206 \pm 37$ & $\mathrm{n} . \mathrm{s}$ \\
\hline
\end{tabular}

Vathes represent mean $\pm S D$ : $p$ vidue of $<0.05$ considered to be signiticant;

n.s.- Nonsigniticant. * MPO=Plasma Myeloperoxidase, $v W F=$ won Willebrand factor

\section{Endothelial activity and RBC adhesion: SVCAM-1, FN and IL-8 (Tables IX.2 and IX.3)}

Like in our previous studies ${ }^{20.24}$ SVCAM-1 levels were increased in steady state compared to normal controls $(\mathrm{p}<0.05)$. Following HU treatment the levels decreased significantly $(\mathrm{p}<0.05)$. The steady state FN levels of the patients were similar compared to normal controls and remained unchanged during 5 months of 
HU therapy. Steady state IL-8 levels were increased in 4 patients A,D.F, and G. The steady state IL-8 levels correlated with the WBC number but not with the HbF levels. Following HU treatment the $\| \mathrm{L}-8$ levels did not change consistently. However, Patients $G$ and $H$ did show an increase of IL-8 at the time of their specific complaints. In the case of patient $C$ no enhanced IL- 8 level was registered despite the fact that he experienced an acute chest syndrome. However, blood sampling as prescribed by the protocol of this study, was performed only once a month and in fact accurred 4 days before the vasoocclusive complication.

\section{Neutrophil activity: sL-Selectin, sIL-6 receptor- $\alpha$ and MPO (Table IX.2)}

The baseline sL-Selectin, SIL-6 receptor-a and MPO levels of the patients were comparable to normal healthy controls. The sL-Selectin and sIL-6 receptor-a levels were not influenced by HU but MPO levels decreased. Correction of the MPO levels for the number of circulating WBC also confirmed the decrease of MPO.

\section{Platelet activity: wWF (Tables IX.2 and IX.3)}

Steady state VWF levels were increased in 6 out of 8 patients. No correlation could be detected between the VWF levels and the number of platelets, HbF, fibronectin or the IL-8 levels. During HU therapy the levels decreased slightly in the majority of patients, but the change was not significant.

\section{Discussion}

The clinical course of SS patients is characterized by symptoms due to hemolytic anemia and complications arising from microvascular occlusion. The vasoocclusion and tissue damage is the end result of a process that involves many steps. Adhesion of young, deformable RBCs to postcapillary, venular endothelium is believed to initiate vaso-occlusion. Several other factors, such as plasma proteins, cytokines, procoagulant and circulatory factors, neutrophil activity and endotheliat abnormalities, may also be involved in the initiation of vaso-occlusion or may enhance adhesion and tissue damage ${ }^{7.50 .14 .20}$. Propagation of the vaso-occlusive crisis is thought to involve trapping of dense and irreversibly sickled cells in the microvasculature with consequent total obstruction and tissue damage. The mechanisms that determine the resolution phase of vaso-occlusion or reconvalescence remain targely unspecified. When treating SS patients with HU, improvement of their hematological values is exident and is attributed to $\mathrm{HbF}$ induction. However, there is evidence that suggests that clinical improvement during HU therapy is not only the result of increase of $\mathrm{HbF}$, but also dependent on several factors that modulate adherence of blood cells to vascular endothelium. 
In addition to the amelioration of the hematological data and increase of $\mathrm{HbF}$ during HU treatment of SS patients in this study, the majority of patients showed a significant decrease of sVCAM-1 levels. The decrease of sVCAM-1, being a soluble receptor specific for $\mathrm{RBC}$ adhesion to endothelium, most likely reflects reduced adhesion of immature $\mathrm{RBCs}$ to endothelium during $\mathrm{HU}$ treatment. This is also in agreement with the study of Styles et al. ${ }^{22}$ that showed a decrease of VLA-4 and CD36 on reticulocytes in SS patients treated with HU. Baseline IL-8 levels seemed increased in half of the patients, but remained unchanged during $\mathrm{HU}$ therapy. However, the IL-8 level and number of WBC correlated well with clinical events. Interpretation of FN levels, detected with commercial kits as specified in this study, is obscured for these tests do not provide a distinction between the 2 known forms of FN (cellular/endothelial FN and acute-phase reactant FN).

No effects of HU on soluble -granulocyte specific- adhesion molecules, sL-Selectin and slL-6 receptor-a, were observed. However, the plasma MPO levels decreased significantly. MPO, a lysosomal protease produced by neutrophils, is synthesized during the very early stages of neutrophil development ${ }^{25}$. It is involved in the mechanisms that cause endothelial injury and damage of the interstium after adhesion of the neutrophill to endothelium has occurred ${ }^{26}$. The decrease of MPO levels may be explained by special effects of HU on granulocyte proliferation or MPO production. The findings suggest that not only a reduction in neutrophil count, but also a decrease of MPO, rather than a reduction in individual neutrophil adhesion, may help limit the extend of tissue destruction and the severity of pain in HU treated patients.

The enhanced steady state plasma vWF levels in most of the SS patients probably reflecthe presence of activated platelets and their interaction with vascular endothelium which is in agreement with earlier studies?. Although HU therapy produced a decrease of the WWF level in some patients, the changes did not reach statistical significance. This could be explained either by the small sample size or a lack of direct effect of HU on platelets.

We conclude that in sickle cell anemia the activated endothelium state and increased adherence of young RBCs set the stage for vaso-occlusion, while many other factors can influence the adherence of cells as well as the process of microvascular obstruction. Our results showed a decrease of sVCAM-1 during HU therapy reflecting less endothelial-RBC interaction. Also the MPO levels, but not the neutrophil specific soluble adhesion molecules, decreased in response to $\mathrm{HU}$ treatment, suggesting a specific effect of HU on neutrophil proliferation or MPO production. This finding may represent a new clinical important action of HU in sickle cell anemia 


\section{References}

1. Charache $S$, Terrin ML, Moore RD, Dover GJ, Barton FB, Eckert SV. McMahon RP, Bonds DR and the Investigators of the Multicenter Study of Hydroxymrea inSickle Cell Anemia. Effect of hydroxyurea on the frequency of painfull crises in sickle cell anemia. N Engl I Med 1995; 332: 1317-1322.

2. Vichinsky EP, Lubin BH. A cautionary note regarding hydroxyurea in sickle cell disease. Blood 1994; 83:1124-1128.

3. Saleh AW, H. Velvis, Hillen HFP, Gu L-H. Huisman THI. Hydroxyurea therapy in sickle cell anemia patients in Curacao. The Netherlands Antilles. Acta Haematol 1997; $98: 125-129$.

4. Adragna NC, Fonseca P, Lauf PK. Hydroxyurea affects cell morphology, cation transport, and red blood cell adhesion in cultured vascular endohellal cells. Blood 1994; 83: 553-560.

5. Swerlick RA, Eckman JR, Kumar A, Jeitler M, Wick TM. Reticulocytes from patients with sickle cell anemia express the a4bl-integrin complex and bind to TNF-a stimulated endothelial cells via a VCAM-1-a4bl dependent mechanism. Blood 1993; 82: 1891-1899.

6. Kaul DK, Fabry ME, Nagel RL. Microvascular sites and characteristics of sickle cell adhesion to wascular endothelium in shear flow conditions: Pathophysiological implications. Proc Nat Acad Sci (USA) 1989; 86:3356-3360.

7. Juneja HS. Pathophysiology and management of sickle cell pain crisis. Lancet 1995 ; 346: 1408-1411.

8. Vordermeier S, Singh S, Biggerstaff J Harrison P, Grech H, Pearson TC, Dumonde DC. Brown KA. Red blood cells from patients with sickle cell disease exhibit an increased adherence to cultured endothelium pretreated with tumor necrosis factor (TNF). Br J Haematol 1992; 81: 591-597.

9. Antonucci R, Walker R. Herion I, Orringer E: Enhancement of sickle erythrocyte. adherence to endothelum by autologous platelets. An I Hematol 1990; 34:44-48.

10. Fadlon E, Vordemeier S, Pearson TC, Mire-Sluis AR, Dumonde DC, Phillips $\|$, Fishlock $\mathrm{K}$, Alun Brown $\mathrm{K}$. Blood polymorphonuclear leucocytes from the majority of sickle cell patients in the crisis phase of the disease show enbanced adhesion to vascular endothelium and increased expression of CD 64. Blood 1998; $91: 266-274$

11. Platt OS, Thoringion BD, Brambilla DI, Milner PF, Rosse WF, Vichinsky E, Kinney TR: Pain in sickle cell disease. Rates and risk factors. N Engl I Med 1991; 325: $11-16.35$.

12. Kasschau MR, Barabino GA, Bridges KR, Golan DE. Adhesion of sickle neutrophils and erythrocytes to fibronectin. Blood 1996; 87: 771-780.

13. Wantier JL, Pintigny D, Wautier MP, Paton RC, Galacteros F, Passa P. Caen JP: Fibrinogen, a modulator of erythrocyle adhesion 10 vascular endothelium. I Lab Clin Med 1983; 101: $911-918$.

14. Wick TM. Moake IL, Udden MM, McIntire LV. Unusually large von Willebrand factor multimers preferentially promote young sickle and nonsicklie erythrocyle adhesion to endothelial cells. Am J Hematol 1993; 42: 284-292. 
15. Brittain HA, Eckman JR, Swerlick RA. Howard RI, Wick TM. Thrombospondin from activated platelets promotes sickle erythrocyte adherence to human microvascular endothelium under physiologic flow: a potential role for platelet activation in sickle cell waso-occlusion. Blood 1993;81:2137-2143.

16. Natarajan M, Mclntire LV, Udden M, Moake J. Adhesion of sickle cells and damage to $/ \mathrm{L}-1$ stimulated endothelial cells under flow conditions in vitro. Ann Biomed Eng 1994; 22: 26 a (abstract).

17. Oppenheim JJ, Zachariae COC, Mukaida N, Matsushima K. Properties of the novel proinflammatory supergene iintercrine i cytokine family. Ann Rev Immunol 1991 ; 9: $617 \times 148$.

18. Darbonne WC, Rice GC, Mohler MA, Apple T, Hebert CA, Valente AJ, Baker JB. Red blood cells are a sink for interleukin-8, a leucocyte chemotaxin. J Clin Invest $1991 ; 88: 1362$.

19. Solovey A. Yi Lin BS, Browne P, Choong S, Wayner E, Hebbel RP. Circulating activated endothelial cells in sickle cell anemia. $N$ Engl I Med 1997; 337: $1584-1590$.

20. Duits AJ, Pieters RC. Saleh AW, van Rosmalen E, Katerberg H, Berend K, Rojer RA. Enhanced levels of soluble VCAM- 1 in sickle cell patients and their specific increment during vaso-occlusive crisis. Clin Immun Tmmunopathol 1996; 81: 96-98.

21. Ballas SK, Dover GJ, Charache S. Effect of hydroxyurea on the rheological properties of sickle erythrocytes in wivo. Am I Hematoll 1989; 32: 104-1]1.

22. Styles LA, Lubin B, Vichinsky E, Lawrence $S$, Hua $M$, Test $S$, Kuypers F. Decrease of very late activition antigen-4 and CD36 on reticulocytes in sickle cell patients treated with Hydroxyurea. Blood 1997; 89: 2554-2559.

23. Biss $\mathrm{E} \mathrm{E}$, Wieland $\mathrm{H}$. High performance liquid chromatographic separation of human haemoglobins: Simultaneous quantitation of foetal and glycated haemo-globins. I Chromatogr 1988;434: 95-110.

24. Saleh AW, Duits AJ, Gerbers A, de Vries C, Hillen HFP. Cytokines and soluble adhesion molecules in sickle cell anemia patients during hydroxyurea therapy. Acta Haematol 1998 (in press).

25. Berliner $N$, Hsing A, Graubert $T$, Sigurdsson $F$, Zain $M$, Bruno E, Hoffman $R$. Granulocyte colony-stimulating tactor induction of normal human bone marrow progenitors results in neutrophil-specific gene expression. Blood 1995; 85: 799-803.

26. Harlan JM, Schwartz BR, Reidy MA, Schwartz SM, Ochs HD, Harker LA. Activated neutrophils disnupt endothelial monolayer integrity by an oxygen radicalindependent mechanism. Lab Invest 1985; 52: 141-150. 


\section{Chapter X}

Summary and conclusive remarks 


\section{Summary and conclusive remarks}

Sickle cell anemia, being the most common hereditary hemolytic anemia in the world, still presents a difficult medical problem. The cytotoxic agen hydroxyurea has recently shown to cause clinical amelioration in some sickle cell patients but it remains difficult to predict which patients will benefit from herapy with this drug. The beneficial effect of hydroxyurea has been mainly atributed to the induction of fetal hemoglobin $(\mathrm{HbF})$. In this thesis it was investigated if the clinical effects of hydroxyurea in sickle cell (SS) patients were due to HbF induction only, or whether other mechanisms were also involved. Moreover, patients treated with hydroxyurea were studied in order to find some criteria that would adequately predict which patients would benefit from this treatment. Also, the effects on $\mathrm{HbF}$ production of isobutyramide, a non-cytotoxic alternative to hydroxyurea, were studied.

In Chapter I a discussion on the pathophysiology, diagnosis and treatment of sickle cell anemia is presented. Standing at the basis of the disease is a point mutation in the $\beta$ globin gene which results in a substitution of the amino acid valine for glutamine at position 6 in the $\beta$ chain of hemoglobin giving rise to the abnormal hemoglobin $S$. Hemoglobin $S$ will polymerize in deoxygenated state and thus may form large strands of polymeres which cause the red blood cell to deform (typically a sickle shape) and interrupt red cell membrane function. Abnormal adherence, sludging and microvascular occlusion by sickle cells may cause ischemic damage which is clinically expressed as pain crises or specific organ vaso-occlusion. Hemolysis, another important clinical feature, results from increased breakdown of sickled cells. However, the clinical severity of disease of the SS patients reveals marked differences and may be influenced by many factors such as those that affect the HbF level and coexistent $\alpha$-thalassemia, factors determining the level of total hemoglobin and other hematological parameters, plasma components, vascular and envirommental factors. The severity of sickle cell disease also correlates very well with the leucocyte count and the number of young deformable sickle cells which are known for their tendency to adhere to vascular endothelium. This adherence may be significantly modulated by the degree of imbalance in substances like nitric oxide, prostacyclins, platelet derived growth factor, endothelin, free oxygen radicals, proagulant factors, ligand proteins and cytokines that all interact with endothelium. The other factors that play a role in the clinical expression of disease are the extend of prior organ damage, changes in properties of the red blood cell itself and environmental factors. Treatment of the patient with sickle cell disease is still mainly supportive and symptomatic. Improved nutrition, better living standards, treatment and prevention of infections (vaccinations and antibiotic treatment) are responsible for the increase in life expectancy of SS patients during 
the last decades. Rehydration, oxygen delivery, analgesia and in some situations antibiotics and exchange transfusions, help to relieve vaso-occlusive crises. Pharmacological HbF stimulation by hydroxyurea has resulted in improvement of symptoms in some patients. In the near future, butyrates and hematopoietic growth factors that also induce HbF synthesis could perhaps be useful either as combination treatment with hydroxyurea or as an alternative to hydroxyurea. Other chemical products that have been tried to ameliorate or prevent symptoms of the disease are drugs that have an antisickling effect, agents that increase oxygen affinity or promote capillary flow and anticoagulation. The benefit of most of these agents could not be confirmed in controlled trials and for some the data from ongoing trials are still unavailable. Experience with allogenic bone marrow transplantation for sickle cell disease has increased considerably, but transplantation still carries a mortality of $10 \%$, as well as a risk of infertility. Moreover, there are still no data on chemotherapy-induced malignancies. Gene therapy, still the subject of intensive investigate research at the laboratory level, is considered to become the treatment of choice in the future. Meanwhile, with the growing knowledge of mechanisms of cellular adhesion, therapies that intervene at the level of cell adhesion to vascular endothelium should be explored.

Chapter II focuses on epidemiological and clinical aspects of SS disease in Curaçao using laboratory data, information on $\beta^{s}$ haplotypes, $\alpha$-gene number and clinical features of a local group of 18 SS patients. Based on the findings in this group, the majority of the estimated 100 local SS patients are expected to carry haplotype $19 / 19$ or the Benin type. The combination of $\mathrm{HbS}$ or $\mathrm{HbC}$ with $\alpha$-thalassemia carries an incidence of $4,1 \%$. No attempt has been made so far to detect compound heterozygotes for HbS and $\beta$-thalassemia. The painful crises and chronic hemolysis are the most common clinical presentations. Legulcers also have a high incidence and often reoccur repetitively in the same individual. The acute chest syndrome has a lower incidence but may be lifethreatening and is the most. common cause of death in sickle cell patients in Curaçao. Before the sixthies the average life expectancy of local SS patients was reported to be 20 years but this figure has undoubtedly improved in view of the advances in local health care over the past three decades. Environmental and psychosocial aspects as well as local management are briefly discussed.

Chapter III provides a review on the regulation and role of the HbF level as well as on the factors that influence the $\mathrm{HbF}$ levels. The clinical significance of $\mathrm{HbF}$ and the rationale of $\mathrm{HbF}$ induction in sickle cell anemia are discussed. The generally accepted fact that increased HbF levels have an inhibitory effect on sickling and ameliorate the clinical course of sickle cell disease has triggered research of pharmacological compounds that stimulate $\mathrm{HbF}$ synthesis. Agents such as 
hydroxyurea, butyrate and its derivatives, erythropoietin and other hematopoietic growth factors have been shown to induce HbF production. The mechanism of action and clinical effects of these agents are reviewed.

The main objectives of the studies (chapter IV) described in this thesis were: A) to analyse the effects of hydroxyurea and the oral butyrate derivative, isobutyramide, on $\mathrm{HbF}$ production in sickle cell anemia. B) To determine which factors may predict the $\mathrm{HbF}$ as well as the clinical response of SS patients, and C) to study the effects of hydroxyurea on cytokines and soluble adhesion molecules, specifically involved in adherence of red cells and neutrophils to vascular endothelium, as well as hydroxyurea effects on endothelial and neutrophil activity and the procoagulant von Willebrand Factor.

Chapter $V$ offers a short description on the methods that were used for detection and quantification of the various parameters that were studied in this thesis.

Chapter VI. The effects of isobutyramide on HbF synthesis were analysed as a treatment alternative to hydroxyurea, which is theoretically assumed to have an carcinogenic potential. Isobutyramide, an oral derivative of butyrate with a long half life, was administered to SS patients over a period of three months. The dosage was started at $50 \mathrm{mg} / \mathrm{kg} /$ day and increased in increments of $25 \mathrm{mg} / \mathrm{kg}$ up to $150 \mathrm{mg} / \mathrm{kg} / \mathrm{day}$. The maximum dose was maintained for three weeks. No significant change in $\mathrm{HbF}$ levels occurred but at the maximum dose of isobutyramide a relative increase of ${ }^{c} \gamma_{-}$levels (one of the two globin chains of $\mathrm{HbF}$ ) was observed. While in three patients the rate of hemolysis remained stable during treatment, one patient revealed an increase in lactate dehydrogenase. None of them experienced painful crises or other vaso-occlusive events. All patients developed temporary epigastric discomfort related to ingestion of isobutyramide. The trial was terminated when the epigastric discomfort turned to persistent intolerable dyspepsia in one patient. In view of these findings treatment with isobutyramide can not be recommended as a addition or alternative to hydroxyurea therapy.

During the first study with hydroxyurea in Curaçao (chapter VII) nine SS patients (eight with haplotype $19 / 19$ and one with haplotype 19/3) have been treated during a 10 month period. Six of these patients were again treated with the drug during five months after an intermission of one year. Their individual hematological and clinical responses to this treatment are discussed. The hematological and biochemical values, the $\mathrm{HbF}$ level and the number of painful crises improve during therapy with hydroxyurea. However, although some patienis experience clinical amelioration, the older patients as well as the patient carrying haplotype 19/3 (or 
Benin/Senegal type) did not observe any changes in their condition. Also, one patient experienced a life-threatening liver sequestration crisis during treatment. It is concluded that the selection of patients who may benefit from hydroxyurea needs further evaluation. Furthermore, effects of hydroxyurea that may influence the clinical outcome other than by HbF induction, in particular effects on cellular adhesion, cytokines, vascular endothelium, neutrophil and platelet activity as well as procoagulant factors should be analysed.

Chapter VIII highlights the effects of hydroxyurea on soluble adhesion molecules (plasma representatives of specific membrane integrated adhesion molecules) and cytokine behaviour in seven SS patients. Baseline values of interleukin-3, interleukin-6, erythropoietin, granulocyte-macrophage colony stimulating factor (GM-CSF), stem cell factor (SCF) and soluble adhesion molecules (sVCAM-1, sICAM-1, sE-Selectin and SP-Selectin) in SS patients are compared with normal adult controls and the cytokines and soluble adhesion molecules have been determined wice during a five month treatment with hydroxyurea. Results show no detectable effect on soluble adhesion molecules during hydroxyurea treatment, but the baseline levels of SVCAM-1 are enhanced in SS patients compared to normal controls. The sVCAM-I levels during hydroxyurea therapy appear difficult to interpret due to fluctuation caused by clinical events. Baseline SCF levels in the SS patients are significantly reduced compared to normal adult controls. The explanation for this finding could be similar to the mechanism that has been postulated by others to clarify the relatively low erythropoietin in SS patients. The mechanism involves increased activity of other plasma factors which render circulating red progenitor cells much more sensitive to erythropoietin. Baseline levels of GM-CSF, interleukin-3 and interleukin-6 interleukin-3 in SS patients were equivalent to normal adult controls. Except for interleukin-3, the cytokines remained stable or revealed inconsistent changes during hydroxyurea therapy. Interleukin-3 showed an increase which paralelled the HbF increase in six patients during hydroxyurea therapy, suggesting that hydroxyurea may induce early erythroid progenitors capable of producing HbF production by a direct or indirect effect on interleukin-3 production.

Chapter $\mathbb{X X}$ discusses the effects of hydroxyurea on endothelial factors (such as IL8, fibronectin and SVCAM-1), neutrophil soluble adhesion molecules (sL-Selectin, sIL-6 receptor- $\alpha$ ), and neutrophil activity (myeloperoxidase) as well as the procoagulant von Willebrand Factor.

These determinants of adhesion and vasoocclusion are compared with hematological and clinical data in a group of eight SS patients before and during five months of hydroxyurea treatment. Steady state sVCAM-1 levels are increased in all SS patients and a significant decrease is noted during hydroxyurea treatment implying 
a decrease in the red cell- endothelial interaction. IL-8 levels are comparable to those in normal controls and remain unaffected by hydroxyurea therapy. Intercurrent infection and crises reveal significant increases in $1 \mathrm{~L}-8$ which are accompanied by leucocytosis, but otherwise the IL- 8 levels do not correlate with hematological data. Hydroxyurea does not affect levels of fibronectin or soluble neutrophil adhesion molecules. However, the levels of myeloperoxidase decrease significantly while leucocyte counts do not, suggesting a reduction in neutrophil activity which may help limit the extend of tissue destruction in the event of a vasooclusive crisis.

\section{Conclusive remarks}

The data presented in this thesis as well as other studies show that most sickle cell patients respond to hydroxyurea therapy with increase of $\mathrm{HbF}$ and a reduction in the rate of hemolysis. The consequent increase in hemoglobin diminishes transfusion requirements which may benefit patients that suffer of very low hemoglobin levels. Moreover, some patients experience a reduction in their frequency of painful crises. Still, the therapeutic effects of hydroxyurea in a sickle cell patient cannot be adequately predicted and the evaluation of significant clinical effect by laboratory means also has its shortcomings. The HbF increase in response to hydroxyurea differs widely between SS individuals. New information from a study by Steinberg (Semin Hematol $1997 ; 34 ; 8-14$ ) reveals that increases in HbF are greatest in patients who have the highest baseline counts of reticulocytes and leucocytes, have one or more episodes of myelotoxicity and absence of the Bantu haplotype. Also, HbF levels during hydroxyurea therapy vary in time with only half of the patients showing a sustained HbF increase after 2 years. These SS individuals apparently have sufficient bone marrow reserve to continue to respond to myelotoxicity with proliferation of $\mathrm{HbF}$ producing erythroblasts. Probably reticulocyte and neutrophil counts are a measure of this bone marrow reserve. Patients older than 40 years should be expected not to gain much from hydroxyurea therapy since they have less frequent pain crises and are more prone to myelotoxicity because of diminished bone marrow reserve. Moreover, it is doublful if patients with a less severe phenotypical expression of disease, like the Senegal or Saudi Arabian-Indian haplotype, will experience significant clinical benefit from hydroxyurea since they already carry high HbF levels. The identification of the SS individuals that qualify for hydroxyurea treatment is even more important due 10 the fact that hydroxyurea still poses a theoretical threat of carcinogenicity and teratogenicity. In addition to the influence of HbF on the clinical presentation of sickle cell anemia, the enhanced tendency of young deformable sickle cells to adhere to endothelium is also of critical importance to clinical course of the disease. The interpretation of clinical response to drug therapy should therefore include practical methods that determine the intensity of blood cell-endothelium 
interaction. Circulating activated endothelial cells, enhanced steady state levels of sVCAM- $\Perp$ in sickle cell patients compared to nomal controls and increase of sVCAM- 1 at the start of the vaso-occlusive crisis suggest the presence of a chronic activated endothelium state with increased sensitivity to certain crisis-precipitating factors as well as specific involvement of SVCAM-1 in red cell -endothelium interaction. The decrease of sVCAM-1, VLA-4/CD36 reticulocytes and myeloperoxidase levels following hydroxyurea therapy, are proof of beneficial actions of hydroxyurea other than its effects on $\mathrm{HbF}$ production. A combination of these parameters should be followed during future treatment of SS patients with hydroxyurea or other compounds in order to adequately predict and confirm clinical responses.

Regarding the follow up of SS patients during treatment with hydroxyurea, it is important to indicate that regular control should not only include careful monitoring of blood counts, but also of the packed cell volume. A High packed cell volume in the case of the SS patient usually in excess of $0.30 \mathrm{l} / \mathrm{l}$ - results in a significant higher blood viscosity which may cause serious vaso-occlusive conplications.

Oral derivatives of butyrate as well as certain hematopoietic growth factors could perhaps become alternatives to therapy with hydroxyurea particularly because they lack the myelotoxic effects and do not pose a risk of carcinogenicity. Isobutyramide, the drug tested in SS patients on Curaçao, did not qualify as effective therapy. There exists a narrow therapeutic margin which also holds true for butyrate as shown in other studies. Perhaps other oral butyrate analogues now under investigation may proof to possess better pharmacological qualities as well as being more potent $\mathrm{HbF}$ inducers. Combination of high dose erythropoietin with hydroxyurea and iron supplements has shown superior $\mathrm{HbF}$ increases but effects on clinical symptoms have not been adequately analysed and the financial costs involved with this treatment are extremely high. Due to these high costs it is doubted that this regimen will ever be of benefit to sickle cell patients in general. Furthermore, other hematopoietic growth factors should be evaluated with extreme caution since parenteral administration poses a serious risk of initiating a vasooclusive crisis.

Finally, it should be stated that treatment with hydroxyureat or other agents does not replace invaluable supportive measures such as hygiene, proper nutrition, antibiotic treatment and regular counseling. However, in the next decade the $\mathrm{HbF}$ inducing agents and new therapies that are directed at specific mechanisms of adherence, may offer the possibility of clinical improvement to some sickle cell patients until - through gene manipulation - the addition of normal genes to the genome of the sickle cell patient becomes reality. 


\section{References}

1. Steimberg MH. Determinants of fetal hemoglobin response to hydroxyurea. SeminHematol $1997 ; 34: 8-14$.

2. Saleh AW, H.Velvis, Hillen HFP, Gu L-H, Huisman THI. Hydroxyurea therapy in sickle cell anemia patients in Curacao, The Netherlands Antilles. Acta Haematol 1997; 98: 125-129.

3. Solovey A, Yi Lin BS, Browne P, Choong S, Wayner E, Hebbel RP. Circulating activated endothelial cells in sickle cell anemia. $\mathrm{N}$ Engl J Med 1997; 337 : $1584-1590$.

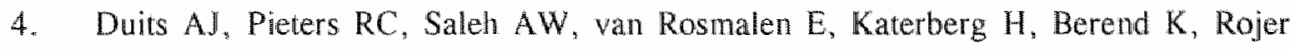
RA. Enhanced levels of soluble VCAM-1 in sickle cell patients and their specific increment during vaso-occlusive crisis. Clin Immun Immunopathol 1996; 81: 96-98.

5. Saleh AW, Duits AJ, Gerbers A, de Vries C, Hillen HFP. Cytokines and soluble adhesion molecules in sickle cell anemia patients during hydroxyurea therapy. Acta Haematol 1998 (in press).

6. Styles LA, Lubin B, Vichinsky E, Lawrence S, Hua M, Test S, Kuypers F. Decrease of very late activition antigen-4 and CD36 on reticulocytes in sickle cell patients treated with Hydroxyurea. Blood 1997; 89: 2554-2559.

7. Saleh AW, Hillen HFP, Duis AJ. Levels of endothelial, neutrophil and platelet specific factors in sickle cell anemia patients during hydroxyurea therapy (submitted).

8. Pieters RC, Rojer RA, Saleh AW, Saleh AEC, Duits AJ. Molgramostim to treat SS-sickle cell leg ulcers. The Lancet 1995; 345: 528 (letter). 


\section{Chapter XI}

\section{Samenvatting}




\section{Samenvatting}

De behandeling van sikkelcelanemie, de meest voorkomende erfelijke hemolytisclie anemie in de wereld, vormt nog steeds een moeilijk medisch probleem. Hydroxyureum blijkt bij sommige patiënten verbetering van klinische symptomen te geven maar de klinische uitwerking is in het algemeen moeilijk te voorspellen. Het effect van deze behandeling is tot nu toe voomamelijk toegeschreven aan inductie van foetaal hemoglobine $(\mathrm{HbF})$. Dit proefschrift heeft onderzocht of de klinische effecten van hydroxyureum alleen berusten op deze HbF inductie of dat er ook andere werkings-mechanismen van belang zijn. Bovendien is aan de hand van verschillende parameters gekeken of een eventueel gunstig klinisch effect van hydroxyureum therapie voorspeld kon worden. Tot slot zijn de effecten op de $\mathrm{HbF}$ synthese onderzocht van isobutyramide, een niet-cytotoxisch alternatief voor hydroxyureum.

In hoofdstuk I worden de pathofysiologie, diagnose en behandeling van sikkelcelanemie beschreven. De cruciale afwijking, te weten een puntmutatie in het $\beta$ globine gen, is verantwoordelijk voor het ontstaan van het abnormale hemoglobine $S$, wat wordt gekarakteriseerd door een substitutie van het aminozuur valine in plaats van glutamine op positie no. 6 in de $\beta$ keten van het hemoglobine molecuul. In gedeoxygeneerde toestand polymeriseert het hemoglobine $S$ en vormt dan multipele strengen van polymeren welke de erythrocyt -karakteristiek sikkelvormig. deformeren, waardoor de erythrocyt membraan functie verstoord wordt. Abnormale adhesie, vertraging van bloeddoorstroming en microvasculaire occlusie door sikkelcellen, kan ischemische beschadiging tot gevolg hebben, welke zich klinisch uit als pijn crisen en/of ischemische beschadiging van specifieke organen. Een ander belangrijk gevolg is hemolyse, wat wordt veroorzaakt door de verhoogde afbraak van sikkelcellen. De ernst van de klinische symptomatologie van HbSS patiënten verschilt per individu en wordt beinvloed door verschillende factoren, zoals bijkomende $\alpha$-thalassemie en factoren, die een effect hebben op het $\mathrm{HbF}$ gehalte, het totale hemoglobine gehalte en andere hematologische parameters, alsmede verscheidene plasma componenten, vasculaire factoren en milieu invloeden. De ernst van sikkelcelziekte blijkt niet alleen goed te correleren met het aantal leucocyten, maar ook met het aantal jonge, reversi-bel, deformeerbare sikkelcellen, welke bekend zijn om hun verhoogde neiging tot adhesie aan de vatwand. Adhesie van sikkelcellen aan endotheel wordt op haar beurt beinvloed door wanverhoudingen tussen stoffen zoals stikstofoxide, prostacyclines, endotheliale groeifactoren (o.a. PDGF), endotheline, vrije zutrstofradicalen, procoagulantia, ligand eiwitten, en cytokines welke allen de functie van het endotheel beinvloeden. Tot slot spelen de eerder opgelopen orgaanschade en specifieke afwijkingen in membraan en cytoplasma van de erythrocyt ook een rol 
bij de klinische expressie van sikkelcelanemie. Behandeling van de patiënt mei sikkelcelanemie is nog steeds voornamelijk ondersteunend en symptomatisch van aard. Adequate voeding, verbeterde leefomstandigheden en vroege behandeling en preventie van infecties (vaccinaties en tijdige antibiotische behandeling) hebben de afgelopen decennia een significante verbetering van de overleving van HbSS patiënten met zich meegebracht. Rehydratie, zuurstof toediening, pijnstilling, en in specifieke situaties, antibiotica en wisseltransfusies, dragen bij tot de verlichting van sikkelcelcrisen. HbF stimulatie door hydroxyureum, veroorzaakt bij sommige patiënten een verbetering van de symptomatologie. Wellicht kunnen in de nabije toekomst nicuwe boterzuurderivaten en hematopoietische groeifactoren, welke ook $\mathrm{HbF}$ inductie veroorzaken, van nut zijn als alternatieve therapie of als combinatie behandeling met hydroxyureum. Andere chemische producten welke zijn uitgeprobeerd om de symptomatologie van de ziekte te verbeteren zijn stoffen die het sikkelen van cellen tegen zouden gaan, middelen die de zuurstofaffiniteit verhogen of de capillaire flow bevorderen en anticoagulantia. Bij de meerderheid van deze studies kon echter geen gunstige respons vastgesteld worden. Sommige trials zijn nog niet afgerond en resultaten zijn nog niet voorhanden. Ervaringen met allogene beenmerg transplantatie bij sikkelcel anemie zijn positief, maar de procedure heeft een mortaliteit van $10 \%$ en een risico op infertiliteit. Bovendien bestaan er nog onvoldoende gegevens over de kans op het ontstaan van een maligniteit als gevolg van de chemotherapie die bij de transplantatie gebruikt wordt. Gentherapie, momenteel nog steeds een onderwerp van intensieve research op laboratorium niveau, zal in de toekomst ongetwijfeld de behandeling van keuze worden. Tussentijds is er, gezien de groeiende kennis van de mechanismen van cellulaire adhesie, zeker plaats voor het ontwikkelen van behandelingen welke ingrijpen op het niveau van adhesie van bloedcellen aan vasculaire endotheel.

In hoofdstuk II wordt ingegaan op epidemiologische en klinische aspecten van sikkelcelziekte op Curnçao. Hierbij is gebruik gemaakt van laboratorium gegevens, $\beta^{s}$ haplotypering, het aantal $\alpha$-genen en de klinische gegevens van 18 lokale HbSS patiënten. Op grond van deze gegevens kan worden aangenomen dat de meerderheid van de geschatte 100 lokale HbSS patiënten het haplotype 19/19 oftewel Benin type dragen. Voorts blijkt uit de literatuur dat lokaal de combinatie van $\mathrm{HbS}$ of $\mathrm{HbC}$ met $\alpha$-thalassemie een incidentie heeft van $4,1 \%$. Er bestaat tot dusver geen informatie over het vórkomen van combinaties wan HbS met andere Ho varianten en $\beta$-thalassemie. De pijncrisen en chronische hemolyse vormen de meest voorkomende klinische presentatie. Recidiverende ulcera aan de benen hebben eveneens een relatief hoge incidentie. Het "chest syndroom" heeft een lage incidentie maar is levensbedreigend en vormt de belangrijkste doodsoorzaak van sikkelcelpatiënten op Curaçao, Veertig jaar geleden was de levensverwachting van de lokale sikkelcelpatiënten 20 jaar. Dit is sindsdien sterk verbeterd als gevolg van 
de vooruitgang in de lokale gezondheidszorg. Invloeden van milieu, psychosociale aspecten en lokale aanpak van sikkelanemie worden kort besproken.

Hoofdstuk III biedt een overzicht van de regulatie van het HbF gehalte en de factoren welke het HoF gehalte beinvloeden. De klinische betekenis van HbF en het nut van $\mathrm{HbF}$ inductie bij sikkelcelpatiënten worden besproken. Het leit dat een hoog HbF gehalte een remmend effect heeft op thet sikkelen en vaak samengaat met. een klinisch milder beloop van sikkelcel anemie heeft aanleiding gegeven tot onderzoek naar farmacologische stoffen, die de HbF productie stimuleren. Verscheidene stoffen zoals hydroxyureum, boterzuur, boterzuurderivaten, erythropoietine en andere hematopoietische grocifactoren zijn in staat on HbF productie te stimuleren. Het werkingsmechanisme en de klinische uitwerking van deze stoffen worden besproken.

De studies in dit proefschrift (hoofdstuk IV) hebben tot doel gehad: A) het bestuderen van het effect van hydroxyureum evenals het orale boterzuur derivaat, isobutyramide, op de productie van foetaal hemoglobine $(\mathrm{HbF})$ bij patiënten met homozygote sikkelcel- anemie (HbSS). B) het bepalen van specifieke factoren bij homozygote sikkelcel-patiënten welke zowel de respons van het $\mathrm{HbF}$-gehalte als de klinische symptomen op hydroxyureum therapie kumen voorspellen, en C) het bestuderen van effecten van hydroxyureum op cytokines and oplosbare adhesie moleculen, welke specifiek betrokken zijn bij de adhesie van erydurocyten en neutrofiele granulocyten aan de vaatwand, evenals de invloed van hydroxyurcum op de activiteit van endotheel, de activiteit van neutrofiele granulocyten en de procoagulant von Willebrand Factor.

In hoofdstuk $V$ worden de methoden, welke gebruikt zijn bij de bepaling van diverse parameters in de studies, toegelicht.

In hoofdstuk VI wordt het effect van isobutyramide op de HbF synthese bestudeerd. Isobutyramide, een oraal derivat van boterzuur met een lange halfwaardetijd, wordt verondersteld, in tegenstelling tot hydroxyureum, geen carcinogene werking te hebben. Het werd toegediend aan vier HbSS patiënten over een periode van drie maanden. De start dosis bedroeg $50 \mathrm{mg} / \mathrm{kg} / \mathrm{dag}$ en werd geleidelijk opgehoogd met $25 \mathrm{mg} / \mathrm{kg} / \mathrm{dag}$ tor een maximum van $150 \mathrm{mg} / \mathrm{kg} / \mathrm{dag}$. De maximum dosis werd gedurende drie weken gehandhatd. Er werden geen significante veranderingen in het $\mathrm{HbF}$ gehalte vastgesteld, maar bij de maximum dosis van isobutyramide ontstond een relatieve toename van ${ }^{{ }^{6}} \gamma$ (één van de twee soorten eiwitketens van het foetale hemoglobine). Drie patiënten toonden geen verandering van hemolyse parameters. Bij éen patiënt echter, werd cen toename van het lactaat dehydrogenase waargenomen. Geen enkele patiënt ontwikkelde cen 
pijncrise of een andere orgaancrise tijdens therapie. Alle vier patiënten ontwikkelden een branderig gevoel in epigastrio aansluitend aan de ingestie van isobutyramide. De trial werd gestaakt als gevolg van het ontwikkelen van onverdragelijke dyspepsie bij ến van de patiënten. Gezien deze bevindingen werd geconcludeerd dat isobutyramide niet beschouwd kan worden als een waardevolle aanvulling op, of alternatief voor, de hydroxyureum behandeling.

In hoofdstuk VII wordt de eerste studie met hydroxyureum in Curaçao besproken. Er zijn negen HbSS patiënten, acht met haplotype $19 / 19$ en én met haplotype 19/3, behandeld gedurende een periode van 10 maanden. Na een pauze van één jaar, zijn zes van deze patiënten opnieuw behandeld met hydroxyureum gedurende vijf maanden. Van elk van de patiënten wordt de hematologische en klinische respons besproken. Gedurende hydroxyureumtherapie verbeterden de hematologische en biochemische parameters, het HbF-gehalte en het aantal pijncrisen. Desondanks ondervonden de oudere patiënten, alsmede de patiënt met haplotype 19/3, geen verandering in hun conditie. Bovendien ontwikkelde één van de patiënten een levensbedreigende leversequestratie-crise gedurende de behandeling. Er wordt geconcludeerd dat er meer criteria gedefinieerd dienen te worden teneinde te kunnen komen tot selectie van die patiënten, die klinisch goed reageren op hydroxyureum. Bovendien is het zinvol, naast de effecten op de $\mathrm{HbF}$ synthese, ook de effecten van hydroxyureum op cellulaire adhesie, cytokines, endotheel, activiteit van granulocyten en thrombocyten alsmede de uitwerking op procoagulantia te onderzoeken.

In hoofdstuk VIII wordt ingegaan op de invloeden van hydroxyureum op oplosbare adhesiemoleculen (plasmavertegenwoordigers van specifieke membraangeintegreerde adhesiemoleculen) en gedrag van cytokines tijdens behandeling met hydroxyureum van zeven HbSS patiënten. Uitgangswaarden van interleukine-3, interleukine-6, erythropoietine, granulocyt-macrofaag kolonie stimulerende factor $(\mathrm{GM}-\mathrm{CSF}$ ), stamcelfactor (SCF) en oplosbare adhesiemoleculen (sVCAM-1, sICAM-1, sE-Selectine en sP-Selectine) van HbSS patiënten werden vergeleken met normale volwassen controle personen. Tijdens de vijf maanden durende behandeling zijn cytokines en oplosbare adhesiemoleculen twee maal bepaald. De resultaten tonen geen significant effect van hydroxyureum op oplosbare adhesiemoleculen. De uitgangswaarden van SVCAM-1 zijn significant verhoogd bij alle patiënten vergeleken met normale controles. De sVCAM spiegels tijdens behandeling blijken moeilijk te interpreteren. Dit wordt verklaard door de mate van fluciuatie van sVCAM-I als gevolg van klinische effecten c.q. complicaties. De uitgangswaarden van SCF zijn significant verlaagd in vergelijking met normale controles. Mogelijk dat deze bevinding verklaard kan worden door hetzelfde mechanisme, dat verantwoordelijk is voor de relatief lage erythropoietine spiegels 
bij HbSS patiënten. Dit mechanisme behelst een toegenomen activiteit van diverse plasmafactoren welke de circulerende voorlopers van de erythrocyt veel gevoeliger maken voor de effecten van erythropoietine. Uitgangswaarden van GM-CSF, interleukine-3 en interleukine-6 van HbSS patiënten waren vergelijkbaar met normale volwassen controle personen. Met uitzondering van interleukine-3 bleven de cytokines stabiel gedurende behandeling. Bij zes van de zeven HbSS patiënien werd een stijging van interleukine-3 parallel aan de $\mathrm{HbF}$ toename waargenomen tijdens hydroxyureumtherapie. Hieruit zou geconcludeerd kunnen worden dat hydroxyureum, via een direct dan wel indirect effect op de interleukine-3 productie, vroege voorlopers van de erythroide reeks induceert, met name die welke in staat zijn tot $\mathrm{HbF}$-productie.

Tot slot worden in hoofdstuk IX de effecten van hydroxyureum op endotheliale factoren (zoals interleukin-8, fibronectine en SVCAM-1) bestudeerd, evenals de effecten op oplosbare adhesiemoleculen van de neutrofiele granulocyt (sL-Selectine, sll-6 receptor $-\alpha$ ), de activiteit van de neutrofiele granulocyt (myeloperoxidase) en de procoagulant von Willebrand Factor. Deze determinanten van adhesie en vasoocclusie zijn bij acht HbSS patiënten bekeken en tegelijkertijd bestudeerd in relatie tot de hematologische en klinische gegevens vóór en gedurende vijl maanden van therapie met hydroxyureum. Uitgangswaarden van sVCAM-1 waren wederom verhoogd in HbSS patiënten. Tijdens hydroxyureum therapie werd ditmaal een significante daling van sVCAM-1 waargenomen hetgeen een afname impliceert in de erythrocyt-endothelium interactie. Interleukine-8 waarden waren vergelijkbaar met die van normale controles en veranderden niet tijdens hydroxyureumtherapie. Echter, intercurrente infectie en crisen werden gekarakteriseerd door een duidelijke stijging van het interleukine-8 gehalte. Behoudens leucocytose tijdens infectie of crise werd er geen duidelijke correlatie tussen IL-8 en hematologische parameters waargenomen. Hydroxyureum bleek geen invloed uit te oefenen op fibronectine of oplosbare adhesie moleculen van de neutrofiele granulocyt. Daarentegen natmen de myeloperoxidase-spiegels significant af, terwijl het aantal leucocyten vrijwel onveranderd bleef. De afname van de activiteit van neutrofiele granulocyten welke hierdoor gesuggereerd wordt, kan in geval van een sikkelcel-vaso-occlusie de uitbreiding van weefseldestructie helpen beperken.

\section{Conclusies}

De resultaten welke gepresenteerd worden in dit proefschrift evenals in andere studies tonen dat de meeste sikkelcelpatiënten reageren op hydroxyureum met een stijging van $\mathrm{HbF}$ en een affname van hemolyse. De daaruit voorkomende stijging van het hemoglobine gehalte veroorzaakt een reductie in de transfusie behoefte hetgeen een klinische verbetering betekent voor patiënten die een erg laag 
homoglobine gehalte hebben. Een aantal patienten ervaart een vermindering van hun pijncrisen. Echter, de therapeutische effecten van hydroxyureum bij de sikkelcelpatiënt kunnen nog niet goed voorspeld worden en de evaluatie van een significant klinisch effect door middel van laboratoriumonderzoeken kent ook tekortkomingen. De toename van HbF tijdens hydroxyureum therapie laat belangrijke interindividuele verschillen zien. Volgens een zeer recente studie van Steinberg (Semin Hematol $1997 ; 34 ; 8-14$ ) wordt de sterkste stijging van HbF waargenomen bij patiënten met de hoogste aantallen reticulocyten en leucocyten, bij patiěnten die ến of meer episoden hebben van myelotoxiciteit en bij afwezigheid van het Bantu haplotype. Ook blijkt het HbF gehalte te varieren in de tijd en slaagt slechts de helft van de patiënten erin om het niveau van HbF toename te handhaven gedurende een twee jaar durende therapie. Deze HbSS patiënten worden gekenmerkt door een goede beenmergreserve welke steeds weer instaat is om te reageren op myelotoxiciteit met proliferatie van $\mathrm{HbF}$-producerende erythroblasten. Waarschijnilik zijn reticulocyt en leucocyt aantallen een maat voor deze beenmergreserve. Patiënten boven de 40 jaar zullen minder baat hebben bij de hydroxyureumtherapie aangezien zij over het algemeen minder pijncrisen hebben en gevoeliger zijn voor myelotoxiciteit als gevolg van geringere beenmergreserve. Bovendien kan betwijfeld worden of patiënten met een minder ernstige klinische expressie van sikkelcelanemie, zoals patiënten met het Senegal of Saudi ArabischeIndiase haplotype, een significante verbetering zullen ervaren bij hydroxyureumtherapie, gelet op het feit dat zij in het algemeen reeds een verhoogd $\mathrm{HbF}$ gehalte hebben. Ook het feit dat hydroxyureum therapie nog steeds een theoretisch risico op carcinogenese en teratogenese draagt, maakt het des te belangrijker HbSS patiënten, welke baat zullen hebben bij hydroxyureum therapie, correct te identificeren. Naast de uitwerking van $\mathrm{HbF}$ inductie op de klinische symptomen, speelt ook de neiging tot adhesie van jonge sikkelcellen aan de vaatwand een kritieke rol. Met betrekking tot de interpretatie van de klinische respons op farmacologische behandeling is het derhalve noodzakelijk dat deze verbeterd en vereenvoudigd kan worden door middel van laboratoriumbepalingen die de intensiteit van bloedcel-endotheel interactie weergeven. Circulerende geactiveerde endotheliale cellen, toegenomen uitgangswaarden van SVCAM-1 in sikkelcelpatiënten ten op zichte van normale controle personen en toename van sVCAM-I bij aanvang van de sikkelcelcrise pleiten voor een chronisch geactiveerd endotheel met verhoogde gevoeligheid voor crisis-uitlokkende factoren evenals een specifieke rol van sVCAM-1 bij de erylurocyt-endotheel interactie. Afname van sVCAM-1, VLA-4/CD36 reticulocyten en myeloperoxidase tijdens hydroxyureumbehandeling is een bewijs van een therapeutische werking van hydroxyureum náast het effect op de HbF productie. Een combinatie van deze parameters zou, bij behandeling van HbSS patiënten met hydroxyureum of andere producten, bepaald dienen te worden teneinde een adequate klinische respons te 
kunnen voorspellen.

Ten aanzien van de follow up van HbSS patiënten tijdens behandeling met hydroxyuream moet opgemerkt worden dat men het bloedbeeld niet alleen dient te controleren op tekenen van myeolotoxiciteit, maar ook op belangrijke veranderingen in de hematocriet. Een verhoogde hematocriet, in geval van de HbSS patiënt meestal boven $0.30 \mathbb{1} /$, veroorzaakt significante stijging van de bloedviscositeit en kan zodoende een ernstige sikkelcelcrise luxeren.

Met betrekking tot de behandeling van patiënten met sikkelcelanemie, zouden orale derivaten van boterzuur evenals bepaalde hematopoietische groeifactoren een alternatief op hydroxyureum therapie kunnen vormen, met name daar zij geen myelotoxische en mutagene werking hebben. Isobutyramide, het orale boterzuur derivaat waarmee enkele HbSS patiënten in Curaçao in trialverband werden behandeld, bleek geen effectieve therapie te zijn. Er bestond een nawe therapeutische breedte zoals reeds bij eerdere studies met intraveneuze behandeling met boterzuur was vastgesteld. Wellicht dat andere orale boterzuur derivaten, welke momenteel onderzocht worden, over betere farmacologische kwaliteiten beschikken en een sterker effect uitoefenen op de HbF $\sim$ productie. Van combinatie van hoge dosis erythropoietine met hydroxyureum en ijzer suppletie is aangetoond dat dit nog sterkere $\mathrm{HbF}$ toename veroorzaakt, maar de klinische effecten werden tot dusver niet goed bestudeerd. Daarbij zij vermeld dat de financiele kosten, gemoeid met deze vorm van behandeling, extreem hoog zijn. In verband met deze hoge kosten is het twijfelachtig of deze behandeling ooit op grote schaal bij sikkelcelpatiënten zal worden toegepast. Bovendien dient het inschakelen van andere groeifactoren bij de behandeling van sikkelcelpatiënten met uiterste voorzichtigheid te geschieden, aangezien parenterale toediening van deze producten als potentieel risico heeft het luxeren van vaso-occlusie.

Tot slot mag gesteld worden dat behandeling met hydroxyureum of andere producten geen vervanging is voor belangrijke ondersteunende maatregels zoals hygiene, goede voeding, antibiotische behandeling en educatie. Desalniettemin, kunnen in de komende tien jaar producten, die HbF induceren en producten die op specifieke plaatsen aangrijpen in het mechanisme van adhesie, klinische vooruitgang bieden an sommige sikkelcelpatiënten. Dit alles uiteraard in afwachting van het moment dat genetische manipulatie de incorporatie van normale $\beta$ genen in het chromosoom tot werkelijkheid maakt. 
Dankwoord 


\section{Dankwoord}

Het uitvoeren van dit wetenschappelijk onderzoek op Curagao, op grote alstand van de academische centra, is een bijzondere uitdaging geweest welke zonder de hulp van menigeen niet zou zijn gelukt. Herbij wil ik dan ook van de gelegenheid gebruik maken om enkele woorden van dank uit te spreken.

In de eerste plaats wil ik mijn opleider in de imwendige geneeskunde in Maastricht, wijlen Prof dr JA Flendrig, danken voor de gelegenheid om de opleiding tor internist bij hem te volgen. In dierbare herimering denk ik terug aan zijn bijzondere kwaliteiten als mens en hoogleraar, en aan de overtuiging waarmee hij mij in van het begin heelt geholpen het sikkelcel onderzoek op te zetten en is blijven stimuleren tot dat hij zijn lak, door ernstige ziekte geveld, moest overdragen.

Wijlen Prof dr JHP Jonxis dank ik zowel voor het bespreken van zijn erwaringen mei mij betreffende hemoglobinopathien in het Craibisch gebied, als voor zijn aanbevelingen ten aanzien van het opzetten van de eerste studies.

Prof dr THJ Huisman (Dept of Biochemistry and Molecular Biology, Medical School of Georgia, Augusta, V.S), het is een voorrecht geweest on samen met $U$ te kunnen werken. Ik ben $U$ veel dank verschuldigd voor de opbouwende kritiek ten aanzien van het proefschrift en alle kennis die U mij, met name betreffende de moleculaire aspecten van hemoglobinopathien, heeft bijgebracht.

Prof dr HFP Hillen, beste Harry, ik waardeer hei bijzonder dat je na het overlijden van Guus Flendrig de begeleiding van dit onderzoek hebt overgenomen. Bij deze hartelijk. dank voor al de adviezen en hulp die je mij hebt gegeven. Zij zijn er uiteindelijk de reden van dat dit proefschrift verwezenlijkt is.

Dr Ashley Duits (klinisch immunoloog, St. Elisabeth Hospitaal, Curaçao), wil ik gaarne danken voor de enthousiaste manier waarop hij heeft meegedacht over, en meegewerkt aan, de uitvoering van het onderzoek op Curaçao.

Het onderzoek zou niet mogelijk zijn. geweest zonder de uitzonderlijke nnedewerking wan de patiënten, welke keer op keer bloed moesten afstaan en trouw hun medicatie innamen.

De leden van de beoordelingscommissie dank ik woor hun bereidwilligheid on her proefschrift te lezen en voor het geven wan wazdevolle opmerkingen.

Dr Karly Hamulyak bedank ik voor de gelegenheid om de von Willebrand Factor te kumnen bepalen en Dr Chris van Engels ben ik erkentelijk voor zijn liulp bij het omzetten van het manuscript in het juste computerformaat. Dr Ru Brummer, beste Robertuan, hartelijk dank voor het steeds belangeloos aanbieden van je hulp tijdens mijn verblijf in Mastricht.

Tiny Wouters ben ik zeer erkenteligk woor het drukklaar maken van dit proefschrift.

Dr Sirving Keli (sociaalgeneeskundige-epidemioloog, St. Elisabeth Hospitaal, Curacao) dank ik voor zijn assistentie bij de statistische bewerking van de resultaten.

Fey wan der Dijs (Hoofd Landstaboratorium, Vredeberg. Curaçao) dank ik voor zijn bijdrage met betrekking tot de actuele gegevens over het voorkomen wan hemoglobinom pathien op Curaçao. Herman Velwis, Ingrid Marini, Zita Winklaar, Rudy Leblanc, Ingrid Genoveva (Landslaboratorium Curaçao), John John Schnog, Leroy Lard, Lisette Mejer, Corlien de Vries, Andrea Gerbers, Leonoor van der Wal, Wieske Owerbeck en Duart 
Dongen ben ik dank verschuldigd voor hun inspanningen binnen het laboratorium. Richard Jansen en Andries van Goethem wil ik danken voor het helpen uitvoeren van de isoburyramide trial.

Carel de Haseth (apotheker, Si Elisabeth Hospitaal) en Norbert Bernadina ben ik dank verschuldigd voor de bereiding in capsules van speciale hoeveelheden hydroxyureum en voor de samenstelling van de isobutyramide suspensie.

Veel lof gaat uit naar mijn grootmoeder, mevrouw Carmen Telgenkamp-Baez. Dankzij haar heb ik in Maastricht gedurende enkele weken, in alle rust en met volledige zorg, mijn manuscript kunnen voltoojen. Mijn moeder en mijn zwager, Julien Puylaert, dank ik voor het net optijd ombouwen van mijn nederlandse samenvatting tot een leesbaar geheel. Professor dr $\mathrm{AEC}$ Saleh, beste $\mathrm{Pa}$, jij hebt mij reeds op een jonge leeftijd de eerste lessen gegeven in de interne geneeskunde en later de fijne kneepjes van het vak bijgebracht. Ik denk dat weinigen dit op zo'n unieke en prettige manier van hun eigen vader leren. Ik hoop nog lang de boeiende casuistiek van het vak met je te kunnen bespreken.

Tot slot dank ik jou Ann Marie, voor je vele opofferingen. Maar niet getreurd het zwembad komt er in ieder geval wél. 


\section{Curriculum Vitae}




\section{Curriculum Vitae}

The author of this thesis was born on november 30, 1959 in Curaçao, The Netherlands Antilles. He graduated in 1978 from the Radulphus College (Atheneum B) in Curaçao. From 1978 until 1983 he studied at the medical faculty of the University of Leiden in the Netherlands where he obtained his doctoral degree. In 1983 he transferred to the medical faculty of Groningen which enabled him to do his internships at the St. Elisabeth Hospital in Curaçao. He received his medical degree in 1985 and started his training in internal medicine at the Department of Internal Medicine of the St. Elisabeth Hospital in Curaçao (head Prof dr AEC Saleh). In 1986 he passed the American Foreign Medical Graduate Examination (FMGEMS). From 1987 he worked at the Deparment of Internal Medicine of the Academic Hospital of Maastricht, The Netherlands (head at that time Prof dr JA Flendrig) where he finished his training in internal medicine. In 1990 he returned to Curaçao where he practices in the St. Elisabeth Hospital with special interest in the field of oncology and gastroenterology. 